\title{
La discòrdia entre ferrers i teixidors al Tirant lo Blanc: entrades reials, imaginari carnavalesc i motius folklòrics ${ }^{1}$
}

\author{
The Fight between Smiths and Weavers in Tirant lo Blanc: \\ Royal Parades, Carnival Imaginary and Folklore Patterns \\ Rafael Beltran \\ (Universitat de València)
}

\begin{abstract}
RESUM
La discòrdia («divís») entre els oficis de ferrers i teixidors, que té lloc en la secció inicial del Tirant lo Blanc (cap. 41), és un dels episodis més coneguts de la novel-la, degut a la seua originalitat temàtica, els seus protagonistes burgesos i el desenllaç sorprenent del conflicte. L'article examina la realitat històrica de les desfilades i entrades reials en l'època, i les disputes entre els oficis que s'hi donen; les crítiques generalitzades als juristes i l'experiència negativa de Joanot Martorell amb juristes; les processons literàries, religioses i carnavalesques, on apareixen els oficis en conflicte; els motius de la forca, els traïdors penjats (com ara Judes) i els penjats cap per avall; i, finalment, el tema del Judici final en rondalles i exemples. En conclusió, el tema de la justícia aplicada arbitràriament parteix de l'àmbit històric, però serà transformat, gràcies a l'ajut de l'imaginari carnavalesc, en una grotesca rondalla folklòrica sobre una decisió injusta, però intel.ligent.
\end{abstract}

\section{Paraules clau}

Joanot Martorell, Tirant lo Blanc, entrades reials, imaginari carnavalesc, motius folklòrics.

\begin{abstract}
The fight (or «division») between the guilds of smiths and weavers, which takes place in the first section of Tirant lo Blanc (Chapter 41), is one of the most well-known episodes in the romance, due to its thematic originality, its bourgeois protagonists and the amazing outcome of the conflict. This article examines the historical reality of the royal parades at the time and the disputes between the guilds that took place during these processions; the widespread criticism of jurists and Joanot Martorell's negative experience with them; the literary, religious and carnival processions, where the conflicting guilds appear; the literary motive of the gallows and the hanged traitor (such as Judas) as well as those hanged upside down; and finally the subject of the Last Judgment in medieval fables and examples.

1. Aquest article forma part del projecte d'investigación FFI2017-82588-P (AEI/FEDER, UE), concedit pel «Ministerio de Economía, Industria y Competitividad» del Govern d'Espanya. Agraïsc a Rafael Narbona la lectura i valuosos comentaris a la part històrica del treball. I a Xavier Renedo i Jacob Mompó la lectura i comentaris a l’esborrany..
\end{abstract}


This research concludes highlighting the fact that arbitrary justice as shown in this episode starts within the historical sphere but is transformed by Martorell, with the help of the carnival imaginary, into a grotesque folk tale about an unjust but intelligent decision.

\section{KEYWORDS}

Joanot Martorell, Tirant lo Blanc, Royal Parades, Carnival Imaginary, Folklore Patterns.

Rebut: 01/09/2020

Acceptat: 30/10/2020

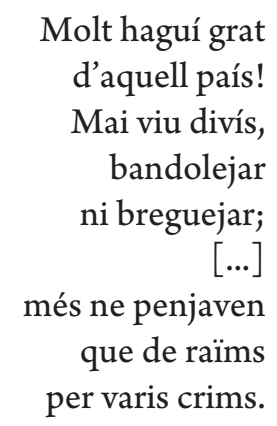

Jaume Roig, Spill, vv. 1642-1656.

\section{La discòrdia entre oficis al Tirant}

El jove cavaller protagonista de Tirant lo Blanc ha promés a Guillem de Varoic tornar a l'ermita després d'assistir a les festes d'Anglaterra celebrades per les noces del rei anglés, que duren un any, per fer-li'n recompte. I, en efecte, al seu regrés Tirant li'n descriurà amb deteniment alguns moments especialment rellevants. Comença per la desfilada amb l'entrada del rei (caps. 4144), a la qual seguiran moltes altres cerimònies. Algunes d'aquestes cerimònies reflecteixen, amb molts punts en comú, les pràctiques de recepció ofertes als reis pels municipis majors de la corona d'Aragó durant el segle XV. I si parem esment a la descripció de la primera secció, trobem que dins del seguici d'estaments -que formava part essencial d'aquesta desfilada de recepció urbanadestaca com a segment autònom i dissonant la discòrdia («divís») entre els oficis de ferrers $\mathrm{i}$ teixidors (cap. 41).

A la desfilada general podem apreciar fins a tretze agrupacions de participants (que després detallarem). La secció dels gremis, on es donarà la discòrdia entre oficis, seria la més nombrosa $\mathrm{o}$ una de les més nombroses, com succeïa a les desfilades històriques; a la novel.la és la tercera i és la secció a la qual l'autor dedica més línies i atenció. En la seua enumeració a Varoic, Tirant comença per «tots los menestrals, cascun ofici ab sa lurea que feta havien», i llavors sembla que li ve a la memòria el record concret -inesborrable- d'un avalot amb rebombori, localitzat al bell mig de la desfilada general de gremis o oficis: «E fon molt gran divís entre los oficis, que yo pensí que los uns ab los altres se matarien». Aquesta al.lusió a un greu aldarull crida lògicament l'atenció de l'oient. No en va, «divís», a l'Espill de Roig, s'associa a «bandolejar»i «breguejar» $»^{2}$. Aleshores, 
Varoic li’n demana a Tirant una explicació més acurada: «iSobre quina causa fon aquesta divisió?». I el jove cavaller bretó concreta els oficis als quals afectava la batussa: «entre los ferrés e los texidós fon lo divís» (Fig. 1 i Fig. 2).

Tirant li explicarà «quina causa» tingué «aquesta divisió», és a dir, els seus orígens o motivacions: «car los texidós de lí deÿen que devien precehir als ferrés, e los ferrés deÿen lo contrari, que ells devien haver la honor dels texidós». I continua amb la resta dels fets següents, entre el que destaca la solució dràstica amb què el «duc de Lencastre» posa fi al conflicte gremial plantejat: el duc mana penjar en la forca sis juristes com a càstig alliçonador. Aquest és el passatge complet:

$-¿$ Sobre quina causa fon aquexa divisió? -dix l'ermità-.

-Senyor -dix Tirant-, yo us ho diré. Entre los ferrés e los texidós fon lo divís, car los texidós de lí deÿen que devien precehir als ferrés, e los ferrés deÿen lo contrari, que ells devien haver la honor dels texidós. Ajustaren-se en cascuna part passats X mília hòmens. E los juristes foren causa de tot açò, car alllegaven per part dels texidós que no.s podia dir missa ni consegrar lo preciós cors de Jesucrist sens drap de li; e los juristes per part dels ferrés al.legaven que primer fon l'ofici de ferrer que no de texidor, per quant lo teler del texidor no podia ésser fet sens ferramenta; perquè ['per la qual cosa'] era provat l'ofici de ferrés ésser més antich e deure precehir als texidós ${ }^{3}$.

Moltes al.legacions se al-legaren per cascuna part que no tinch en recort. E aquesta fon la causa del divís. E si no fos stat lo duch, qui.s trobà a cavall e armat, fort jornada fóra stada, car lo rey ja no y podia dar remey. Lo duch se mès enmig de la pressa de tota la gent e pres sis juristes, tres de cascuna part, e tragué.ls fora de la ciutat. Ells se pensaren que lo duch los volia per demanar quala part tenia millor justícia. Com foren fora de la ciutat, al cap del pont, féu restar mil hòmens de armes que no dexassen passar a negú si la persona del rey no era. Lo duch descavalcà enmig del pont e, tan prestament com pogué, féu posar dues forques ben altes e féu penjar tres juristes en cascuna, cap avall per fer-los molta honor; e no-s partí de allí fins que agueren tramés les miserables ànimes en infern.

Com lo rey sabé tal nova, prestament anà on era lo duch e dix-li semblants paraules:

-Mon oncle, en lo món no.m podíeu fer major plaer e servir del que fet haveu, per quant aquests hòmens de leys fan rics a si mateyx e destroexen tota Anglaterra e tot lo poble. Per què yo man que stiguen açí en las manera que stan fins a demà, e aprés sien-ne fets quartés e posen-los per los camins.

Respòs lo duch:

-Senyor, si la majestat vostra me volia creure, fésseu en vostre regne que no y agués sinó dos juristes, e aquells dins $\mathrm{X}$ o XV dies aguessen determenada qualsevulla causa ab sentència diffinitiva, e dar-los bon salari a cascú. E si prenien res de negú, que no agen altra pena sinó aquesta que havem executada.

E lo pròsper rey manà que axí fos fet.

Sabut per tot lo poble lo virtuós acte que lo duch havia fet, donaren-li infinides lahors, e gens per açò la festa no restà que no.s fes en la forma que era stada ordenada (Martorell, 2005: 196-197). 


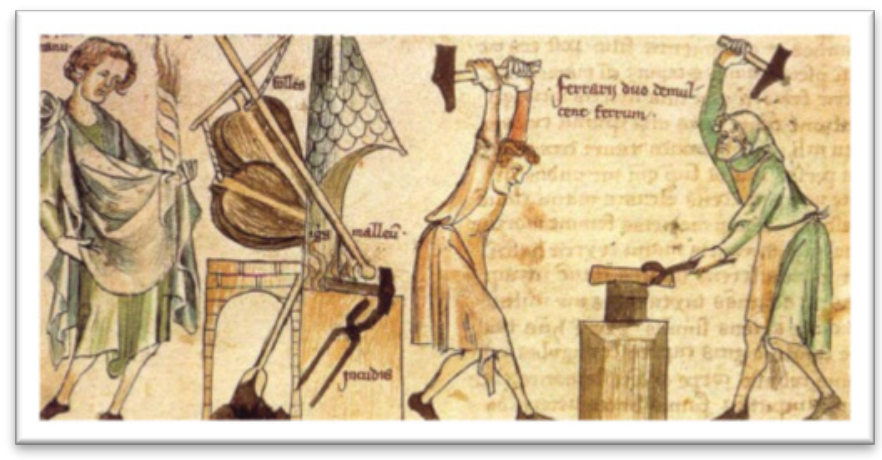

Fig. 1. Ferrers medievals

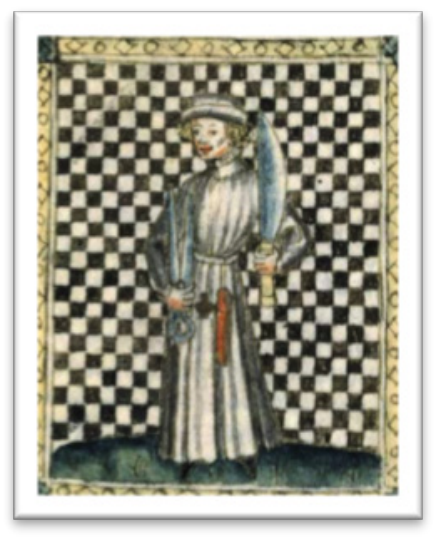

Fig. 2. Teixidor medieval

L'episodi és un dels més singulars i coneguts de Tirant lo Blanc, per la seua originalitat temàtica, pels seus protagonistes burgesos (menestrals i advocats) i sobretot pel desenllaç del conflicte presentat. La resolució final constitueix una cloenda tan brutal que no pot considerar-se més que una burla, però fins i tot més punyent $\mathrm{i}$ cridanera que moltes altres ben reeixides que ens regala la fèrtil imaginació i la persuasió narrativa del novel.lista valencià. Martorell fa servir i juga amb allò que avui la psicologia anomenaria «pensament lateral»o «pensament divergent», però també violència subconscient. La majoria de la gent tendim a tractar de resoldre els problemes de manera lògica, però n'hi ha potser d'altres camins diferents, alternatius, que no estan a la vista però que la creativitat pot traure a la llum, de manera positiva -com en la imaginació literària i artística- 0 negativa i desgavellada -si es du a terme en la realitat.

L'ambigüitat temàtica de l'episodi parteix del fet que la narració del succés es manté en una frontissa entre camps diferents i, fins i tot, oposats: entre la realitat històrica i la ficció, entre la venjança biogràfica i la sàtira social, entre el divertiment i la hipotètica lliçó política o moral. Perquè sens dubte tot hi és desproporcionadament exagerat (o lateral). Es mostren uns caràcters i un exemple gairebé grotescos. Una gresca en principi irrisòria assoleix les dimensions de perillosa revolta («Ajustaren-se en cascuna part passats $\mathrm{X}$ mília hòmens $»)^{4}$, i uns personatges venerables 
i respectats, com eren a l'època -com sempre han sigut- els juristes, reben el càstig de la forca, puniment reservat només als bandolers més criminals i reincidents. A més a més, són penjats dels peus, com es penjaven tradicionalment els traïdors, com ara Judes, els sodomites a la corona de Castella, o els infidels a la corona d’Aragó (vegeu $\$ 7$ ) (Fig. 3 i Fig. 4).

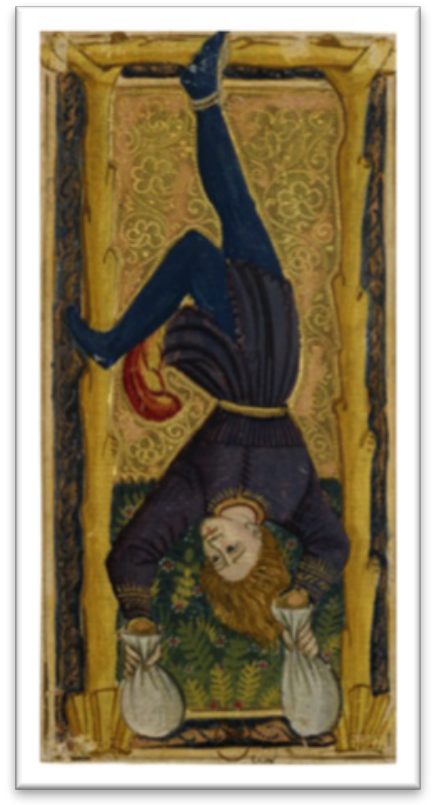

Fig. 3. Judes penjat dels peus, al Tarot dels Medici (s. XV)

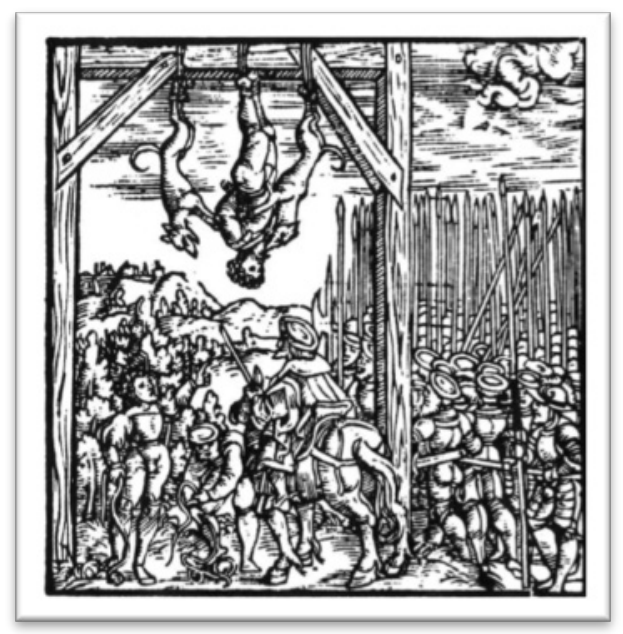

Fig. 4. Execució d'un jueu.

Johannes Stumpf, Chronick wirdiger thaaten Beschreybung (1586) 


\section{La mirada crítica a l'episodi}

Malgrat aquestes paleses exageracions, l'episodi ha estat normalment interpretat des del punt de vista de la versemblança històrica, social -els recels de la noblesa cap a la burgesia d'oficis lliberals, com ara els juristes-, però sobretot biogràfica. Martorell hi podia haver reflectit un personal menyspreu aristocràtic contra els juristes que l'havien fet patir tant durant molts moments conflictius de la seua vida; malvolença present no només durant molts episodis crítics de la seua vida i la de la seua família, sinó també en alguna de les seues lletres de batalla, sobretot les bescanviades amb Joan de Monpalau. Com resumeix Riquer: «Com que ja coneixem l'opinió que Joanot Martorell tenia dels juristes ('dones e juristes, los quals en la ploma i en la llengua tenen tota llur defensió' [...]), no ens ha d'estranyar l'evident satisfacció amb què escriu aquestes ratlles» (1990: $108)^{5}$. Aquesta presumpció de malvolença o «antipatia» havia estat ja ben assumida pels més grans estudiosos de la literatura catalana -com Rubió i Balaguer $-{ }^{6}$ i ha sigut revalidada, sense a penes matisos, pels historiadors i crítics que han comentat l'episodi, per exemple, Vargas Llosa ${ }^{7}$, Borràs i Martínez ${ }^{8}$, Galé ${ }^{9}$, Harney $^{10}$, Rubio Vela ${ }^{11}$, Escartí1 ${ }^{12}$, entre altres.

5. El mateix Riquer afirma, al mateix llibre, a propòsit de les lletres de batalla bescanviades entre Joanot Martorell i Joan de Monpalau: «Aquestes fiblades als juristes i als notaris, conseqüència de dues actituds davant la vida mot típiques del XV -la dels qui cerquen solucions legals i la dels qui cerquen solucions bregoses en els mateixos conflictes-, ens palesen una diferència fonamental entre dos tipus d'escriptors...» [el notari Metge i el cavaller Martorell] (1990: 77). La polarització entre el cavaller (armes) i el jurista i burgés (lletres) ja la remarcava abans: «Home orgullós i bregós, les seves lletres de batalla als seus diversos enemics ens el retraten agut i sorneguerament malintencionat, entusiasta d'una cavalleria aleshores ja en decadència, enemic de mercaders i juristes i partidari de l'acció directa. Però aquestes lletres revelen que era un gran escriptor» (Riquer, 1972: 110). «No oblidem, encara, el menyspreu que Martorell sent envers els juristes, notaris i homes de ploma. Tot plegat ens dibuixa una fisonomia a la qual es fa molt difícil d’aplicar la qualificació de 'burgesa'» (Riquer, 1990: 25).

6. «El anticivilismo, si podemos llamar así a la antipatía de Martorell por los juristas, seis de los cuales son mandados ahorcar por el duque de Lancáster para zanjar una disputa baladí que ellos promovieron, da que pensar y se explica por el descontento que el autor sentiría ante la sentencia recaída en su pleito contra Montpalau» (Rubió i Balaguer, 1953: 790).

7. «El furor temerós del senyor feudal davant aquesta burgesia naixent en la qual endevina una rival, es transparenta l'episodio en què el duc de Lencastre penja sis juristes («e no es partí d’allí fins que hagueren trameses les miserables ànimes en infern»), en l'expulsió de tots els advocats, tret de dos, d’Anglaterra, en la naturalitat amb què Diafebus bada el cap del metge que triga a guarir Tirant. La disputa de ferrers i teixidors que pertorba les bodes del rei d'Anglaterra illlustra les rivalitats entre gremis i corporacions d'artesans que esvalotaven de tant en tant...» (Vargas Llosa [1969] 1985: 33).

8. «Joanot Martorell, ideològicament parlant, és un personatge reaccionari. [Nota:] En aquest sentit cal interpretar l'episodi en què el duc de Lancaster penja sis juristes [...] ja que, pel seu rol i pel fet de pertànyer a un sector social en auge -un estrat "burgés" que augmenta el seu status social a través del servei en l'administració reial-, śenfronten radicalment a la filosofia conservadora de la cavalleria, sobretot si tenim en compte que mitjançant aquest servei poden arribar a ennoblir-se (noblese de robe)» (Borràs i Martínez, 1990: 283, i n. 23).

9. «No parece extraña esta belicosidad que parece mostrar el autor contra el gremio de los juristas y abogados conocida su manifiesta tendencia a solventar sus problemas más por el expeditivo método de los retos y duelos "a ultranza" que por conductos legislativos» (1996-1997: 82-83). Galé aporta en nota un interessant paralllel amb una crítica a la condició volàtil dels «letrados» (comparats amb els mariners que naveguen a l'arbitri dels vents) per part de Pedro Manuel de Urrea, dins el seu Cancionero de 1517.

10. «Tirant lo Blanc expresses its anti-lawyer phobia overtly» (Harney, 2005: 159).

11. A propòsit de les disputes legals entre un Joan Martorell procurador general de Dénia (que coincidiria, per a Rubio Vela, amb el Joanot Martorell autor de Tirant) i el jurista («doctor en lleis») Gabriel de Riusech, diu: «Todo apunta a una venganza personal del abogado [Riusech] contra el caballero con el que había tenido discusiones y desacuerdos, y que tanta antipatía mostraba hacia las gentes de su oficio: 'dones e juristes [...] en la ploma i en la llengua tenen tota llur defensió’ (Rubio Vela, 2010: 75). La cita de «dones e juristes...» correspon a la lletra de 30 de maig de 1437 de Joanot Martorell a Joan de Monpalau (1990: 77).

12. «...aquesta reacció de Martorell, més enllà de la qüestió personal, aniria lligada a la seua nul.la afecció als juristes -tan poc valorats per ell al seu Tirant, on no dubta a penjar-los, en un conegudíssim episodi [...]- que s'ennoblissen, tot adquirint senyorius quan els de la família de Martorell s'havien hagut de vendre» (Escartí, 2012: 397). 
Tanmateix, aquesta explicació, que parteix d'un enfocament i associació en principi ben lògics i simples (Martorell/cavaller $\neq$ juristes/burgesos), no hauria d'excloure ni tancar altres possibilitats orientatives o interpretatives estrictament literàries. Tot el contrari, pense que en demana més. Donada la singularitat de l'episodi, estem autoritzats a deduir que si aquestes línies, a penes un parell de planes, criden l'atenció sorollosament a l'intern del text del Tirant no és -o no és només-perquè puguen transmetre uns ressentiments vitals de l'autor (pensem en els lectors de les traduccions de l'obra, que desconeixien tot sobre Martorell), sinó perquè presenten una solució narrativa insòlita, i tanmateix convincent i homogènia amb el sentit de l'humor d'altres segments de la novel.la. I aquesta solució és fruit i resultat d'una combinació de tonalitats genèriques contradictòries, d'unes tradicions literàries textuals, però també orals i visuals, d'uns imaginaris que de manera atípica es barregen i dissonen, i alhora es complementen. Això sí, és una solució reeixida i exitosa dins el terreny literari, i mai ho podria ser dins el de la historicitat ni el de la biografia.

Segons la mirada exclusiva -o predominant- «autobiogràfica», semblaria que el duc Lencastre podria representar una mena d'alter ego de Martorell, noble fracassat i frustrat que exagera i sublima en la ficció allò que no ha pogut mai fer en la realitat: exercir el dret senyorial anàrquic, la llei sense entrebancs, i dictar directament $\mathrm{i}$ arbitrària la sentència de mort dels juristes com a intèrprets dolents d'aquella mateixa llei. Naturalment, aquesta mirada resulta simple, banal, insatisfactòria i injusta (per a l'autor i per als lectors). En canvi, si adoptem la mirada literària més oberta -genèrica, temàtica, estructural i retòrica-, hi trobarem, com a mínim, tota una sèrie de traces d'allò que Harney, quan comenta aquest episodi, i referit a l'odi als advocats ( $\ll$ hatred of lawyers»), anomena «pre-political folklore of primitive rebellion» (2005: 159). I detectarem aquestes empremtes de «pre-political folklore» principalment dins una sèrie de motius en relats -contes exemplars cultes, rondalles tradicionals- o espectacles públics -religiosos i civils-. Relats o representacions on, com veurem, de vegades les figures d'alguns jutges «savis» (o no tan «savis»), llestos o babaus, llegendaris o ficticis, s'enfronten a querelles i al.legacions absurdes o estrafolàries (com la dels ferrers i teixidors), dicten sentències estrambòtiques (com la del duc), però al remat afavoreixen els humils, els pobres diables acusats injustament, i els lliuren o bé del pagament de la multa, o bé de la presó, o bé de la forca.

En aquest sentit, proposem de bestreta interpretar l'episodi, sense descartar el rerefons del menyspreu de classe o la malvolença personal -«l'opinió que Joanot Martorell tenia dels juristes», com diu Riquer-, també des del punt de vista folklòric, des de l'òptica d'uns motius que ens ofereixen -en sermons, exempla, rondalles, representacions- el repte de gaudir d'una paradoxa, gairebé una aporia, la de la «clever injust decision»: la decisió absurda, però al remat intel.ligent, o útil si més no, presa per una autoritat davant un conflicte de molt difícil o impossible resolució.

$\mathrm{Al}$ remat, Martí de Riquer, tot i que diu que la novel.la està neta de folklore i de simbolismes (1992: 13), també confirma la superioritat del relat de ficció -amb totes les conseqüències-per damunt de la crònica:

... los personajes que se mueven en el Tirant lo Blanch y los hechos que se narran en el libro reflejan lo que era verdad a mediados del siglo XV. Pero esta verdad no la maneja un historiador sino un novelista, que se otorga la libertad de alterar y distorsionar la historia y a veces la geografía, jugando a su antojo con reinos y reyes, con cristianos y moros, inventando conquistas fabulosas y victorias deseadas por sus lectores, haciéndonos de vez 
en cuando un guiño de complicidad y sin importarle lo que pueda opinar el sesudo erudito que imaginara que el Tirant lo Blanch era un libro de historia (1992: 15).

\section{Una realitat històrica: les entrades reials i les disputes entre els oficis}

\subsection{Desfilades i entrades reials}

L'episodi al qual ens referim es presenta a la segona part del cap. 41. El capítol duu per epígraf: «Com Tirant recità a l'hermità les grans festes, solemnitats e magnificències, les quals no-s troben per scriptura tan bells actes com foren fets en les bodes del rey de Anglaterra, e del divís que fon entre.ls oficis». La segona part de l'epígraf se centra exclusivament en el tema de la discòrdia entre els oficis: «del divís que fon entre.ls oficis», perquè efectivament aquest assumpte ocupa tota la segona part del capítol. Tanmateix, la primera part d'aquest epígraf introdueix no només el contingut del capítol, sinó el dels més de cinquanta-cinc capítols següents, donat que el conjunt total de les festes d'Anglaterra (caps. 41-97) depén i gira al voltant de «les grans festes, solemnitat e magnificències» de les bodes (caps. 41-55). Es tracta, primer, de la desfilada o entrada del rei (caps. 41-44), que és la part que ens interessa comentar tot seguit; però després vindran els capítols d'organització per a cada dia de la setmana de les justes i altres activitats (cap. 45-51); i, finalment, el context, els preliminars i la representació de les anomenades «magnificències de la Roca» (cap. 52-55) $)^{13}$.

Vist dins el conjunt d'una pràctica de recepció urbana, desfilada o entrada reial ${ }^{14}$, l'episodi d'aquesta «discòrdia»o «divís» actua com a una mena de suspensió, parèntesi o catàlisi. De manera que quan es tanca aquest parèntesi continua la descripció de l'entrada, al capítol següent, amb les altres dotze seccions de la desfilada (cap. 42). Martorell descriu en primer lloc «la mostra» que va fer el rei el dia de Sant Joan. El primer participant va ser el mateix rei, qui cavalcà des del seu gran palau a la gran plaça de la ciutat, amb «manto» brodat i forlat, gipó, corona i ceptre. Anava acompanyat, anticipa Tirant (recordem que Tirant és el narrador, que descriu i relata els fets a Varoic), de «tots los gentils hòmens que.s trobaren en la ciutat que fossen de quatre cortés» o 'quarters' (és a dir, d'ascendència noble per part de pare i mare). Però llevat del rei, que no comptem, tota la «mostra», la desfilada comença amb [1] el duc de Lencastre, amb un seguici de 15.000 combatents, que hi van fer parada militar davant el rei. Després continua amb [2] el ordes religiosos i amb [3] els menestrals: «Aprés del duch anaven tots los órdens, cascú ab un ciri ençés en la mà. Aprés venien tots los menestrals, cascun ofici ab sa lurea que feta havien».

Després de la desfilada dels menestrals, per oficis, de la qual escollirà com en un zoom d'amplificació la discòrdia entre ferrers i teixidors que en aquest article analitzem, vindran els [4] entremesos (sense especificar-ne temes ni actors), [5] el clero (arquebisbes, bisbes, etc.) i [6] el mateix rei, de nou, acompanyat d'aquells qui volien rebre l'orde de cavalleria.

Hem parlat de coincidència fidel amb la realitat de l'època. Les processons, desfilades o seguicis medievals, com a manifestacions públiques d'organització jeràrquica de la societat, han

13. A més a més, encara en presència de Guillem de Varoic i encara a l’espai de l'ermita, un altre narrador intern, Diafebus, cosí de Tirant, s'ocuparà de narrar -també molt acuradament- les primeres accions cavalleresques de l'heroi de la novellla (caps. 56-97). És a dir, narrarà allò que podríem considerar que entra també dins els «bells actes» de «les bodes del rey de Anglaterra».

14. Raufast $(2006 \mathrm{a}, 2006 \mathrm{~b})$ defén que seria més correcte referir-se a «pràctiques de recepció urbanes», tot i parlant d'«entrades reials», donat que l'agent d'aquests espectacles eren els dirigents municipals, sense (aparent) intervenció règia. Tanmateix, farem servir «entrades reials», com a sintagma més denotatiu i més reconegut a l'hora d'entendre la situació cerimonial. 
sigut ben estudiades pels historiadors de les darreres dècades. També el cas de la ciutat de València, la ciutat natal de Joanot Martorell, s'ha estudiat dins l'especificitat de cerimònies de la corona d'Aragó ${ }^{15}$. Les celebracions a València van posseir i van oferir des dels seus inicis el mateix profund sentit de comunitat coherent i integradora que es pot apreciar en altres casos de la corona d'Aragó, hispànics i europeus ${ }^{16}$. En concret, l'entrada del monarca a València venia de la mà dels seus magistrats, a partir d'una ambaixada de recepció que esperava en els confins del terme de la ciutat per conduir-lo fins un dels seus portals fortificats, generalment el Portal dels Serrans. A l'exterior, davant les portes, el rei contemplava, com passa en Tirant, la desfilada de la menestralia ordenada per corporacions d'oficis sota els seus respectius estendards. Els oficis, com veurem a continuació en el cas de l'entrada de 1459, representaven habitualment tot un seguit de jocs, danses i exercicis de caràcter col-lectiu, inspirats en un imaginari comú a tot el món urbà occidental ${ }^{17}$.

Com també passa en la novel.la (secció [4] del seguici), els entremesos formaven part dels elements més característics i distintius de les entrades, i anaven associats habitualment als oficis. Massip $(2010,2013)$ ha estudiat el tema històric i literari dels entremesos de la corona d'Aragó, des d'una perspectiva interdisciplinària que inclou l'imaginari col-lectiu en el sentit més ampli del concepte ${ }^{18}$. Massip (2013) estudia, en concret, l'entrada reial del primer Trastàmara, Ferran d'Antequera, a València, l'any $1414^{19}$, i en parla de cinc entremesos o representacions escèniques: dos referits a la «Divisa del rei» (el «Verger» i la «Torre», en referència a l'establiment del cavalleresc Orde de la Gerra i el Griu, emblema de Ferran); un tercer que consistia en una roda dels «Set Planetes» i una altra dels «Set fills del rei»; un quart, el més espectacular, la «Roda de les Set Edats de l'Home» (del bressol a la tomba), centrat per la Roda de la Fortuna; i el cinqué, la «Visió de sant Vicent Ferrer», donat que el predicador fou l'artífex principal de l'entronització

15. En especial per Narbona (1993, 2003, 2017, 2019a y 2019b). Vegeu també, entre alguns treballs més recents, Ferrer Valls (1994, 1995), Massip (2013-2014), Martínez Vinal (2018), Muñoz Gómez (2018) i Orts-Ruiz (2019).

16. La mateixa o semblant ordenació podem apreciar per a les entrades reials a les ciutats principals de la corona d’Aragó: Barcelona (Raufast, 2006a, 2006b y 2010), Saragossa (Barraqué, 2008); o de la corona de Castella (Soria Nieto, 1993; De Andrés, 1984; Carrasco, 2013)

17. Com explica Narbona, el seguici presentava els oficis ciutadans amb gales i lliurees noves, segons un ordre establert pel Consell de la ciutat de València des de 1373, i gaudia de subvenció municipal pel que feia a joglars, músics i entremesos. Abans de penetrar dins el recinte emmurallat, el seguici passava davant del rei i li brindava reverència, dirigint-se, amb una marxa incessant, interrompuda només per l'execució dels seus jocs, cap a l'interior de la ciutat. Només llavors el monarca, muntat a cavall i sota palli, entrava a València. Mentrestant, les brides, els cordons honorífics i els bordons eren portats a peu pels més rellevants oficials municipals, pels oficials reials i per una representació dels barons del regne, dels cavallers i de la ciutadania, en un estricte ordre jeràrquic (Narbona, 1993: 466467). Com més recentment assenyala Martínez Vinat: «La manifestación pública del estamento artesanal en este tipo de ceremonias, ya fuera desfilando en el cortejo ciudadano o bien mediante la realización de entremeses y representaciones teatrales, concedía a las corporaciones un escenario privilegiado para reivindicarse y hacer valer la jerarquía profesional entre unos oficios y otros. Las entradas reales, junto a las procesiones confraternales y las luminarias del Corpus Christi, constituían una oportunidad sin igual para exhibir sus señas de identidad (emblemas, banderas con la senyal del 'ofici, vestimentas particulares, etc.) y desarrollar todo un aparato simbólico de legitimación corporativa ante la ciudad y, en este caso, en presencia del monarca. De hecho, al menos desde el siglo XV, es frecuente encontrar en la documentación súplicas dirigidas al rey o al gobierno municipal, insertas en los estatutos profesionales, solicitando permiso para imponer tasas extraordinarias a los agremiados con el fin de sufragar los costes que acarreaba su participación en entrades de reys, nativitats de primogenits, o per algunes necessitats ocorrents» (2018: 131).

18. Massip no només ha estudiat la presència dels entremesos a les entrades reials, alguns a fons, com els de l'entrada de Ferran d’Antequera a València en 1414, sinó també al Tirant, com veurem més endavant, amb aquesta perspectiva d’amplitud, que resulta enormement fructífera.

19. Tot ampliant informació ja avançada al seu llibre (Massip, 2010: 73-95). 
de Ferran a la Corona d'Aragó. Tot un programa dedicat a enaltir la figura del Trastàmara per part de l'urbs, en un afany de congraciar-se amb el nou monarca ${ }^{20}$.

Més prop del temps d'escriptura del Tirant, Melchor Miralles, capellà del rei Magnànim, ressenya en la seua Crónica i dietari, quan la desfilada organitzada per rebre el rei Joan II a València, el 8 de febrer de 1459, la participació de fins a vint-i-nou grups de menestrals, que culminava amb uns moms («gomos») ballant amb màscares, amb tota mena de colors, teixits, complements, música... La lectura d'aquesta acurada descripció ajuda efectivament, com diu Hauf, quan anota l'episodi del Tirant i hi aporta aquesta referència, a «copsar l'esperit de l'època» (Martorell, 2005: 201). Si en fem un extracte, descobrim:

\begin{abstract}
«Començaren a venir los oficis, cascun ab son orde, ab ses banderes e estandards, ab molts juglars, trompeters, ministrers e tamborinos e moltes maneres de sons». [1] Els carnissers «hi portaven un bou»; [2] oripellers; [3] corretgers; [4] obrers de vila; [5] llauradors «anant llaurant i sembrant, e fent algunes coses de riure»; [6] aluders; [7] assaonadors; [8] coltellers; [9] tapiners; [10] flaquers (forners), «tots vestits de blanch, davant lo senyor rei feren la Cena, ço és Jesuchrist ab los apòstols, e aquí cantaren e feren bel entramés»; [11] esparters, «amb roba i barrets d'espart»; [12] corde[1le]rs; [13] teixidors, «ab moltes maneres de vestits, e los més de blau e larchs»; [14] pescadors, $\ll$ ab algubes, e portaven la barqha hon anaven Jesuchrist e sent Pere e sent Andreu, e pexquaven, e fent coses de riure»; [15] ferrers, «tots vestits de blau molt belament, e molts vestien fins en terra; e fien hun bal ab espases nues molt gentil e bel»; [16] barbers; [17] moliners; [18] corredors de col[1]; [19] fusters; [20] sabaters, «fien hun bal molt bel»; [21] pellissers, «anaven molts vestits tots de diverses pels, les pels de fora ab moltes maneres de cares. Havia-y hun jove que hera molt lauger, e féu molt trempaments davant lo senyor rey $\gg^{21}$; [22] armers; [23] corredors d'orella; [24] pellers i calseters; [25] baixadors; [26] sastres; [27]; blanquers [28]; argenters; [29] peraires (cardadors de llana). I «a la fi portaven hun papaló hon anven dintre .viii. gomos, cascú ab sa diversitat de vestidures e de cares, e lo principal ho maestre d'els, lo qual hera frare, com fonch denant lo senyor rey hysqué del papaló e parlà a la francesa ab moltes maneres de gests, molt altament e bé, e dient al senyor rey recomanacions del papa, dels cardenals e bisbes e de tots los reys e duchs e comptes e senyors de Alamanya, e de França e del Realme, e aprés balaren, axí belament que los senyor rey e tots quants hi foren ne agueren molt gran plaer, de la manera de tan bella parleria del dit frare predicador e del balar d'él e de sos companyons» (Miralles, 2011: 258-260) ${ }^{22 .}$
\end{abstract}

Pel que fa a la participació del clero (secció [5] de la desfilada de Tirant), Narbona (1993: 468-69) ha analitzat acuradament el paper del clergat a les entrades sobiranes de València, des de la implicació plena, en 1439, fins al declivi, que es va donar no només per un descens de la col.laboració dels clergues, sinó també dels oficis, a partir precisament de 1459, causat per la dislocació

20. A més a més, per al darrer entremés de Sant Vicent cal consultar l’article de Calvé (2016 i 2019).

21. Els «trempaments» són 'divertiments', 'diversions' o 'solaços'.

22. Vegeu els comentaris i contextualització cabdal de la processó al treball d’Orts-Ruiz (2019: 104-105). Ens podem fer una idea aproximada de la processó amb les magnífiques imatges de la desfilada de gremis, a la processó tradicional del Corpus de València, transmeses a l'Àlbum del Corpus de Francisco Tarín (Figs. 5, 7 i 8). 
que començava a produir l'entrada en joc dels nous espais cerimonials tancats, com ara els salons de Palau reservats a elits més reduïdes ${ }^{23}$.

Fins ací es podria dir que els participants de la desfilada de Tirant coincideixen fidelment amb la realitat urbana de l'època de Martorell (amb l'excepció del «divís» de ferrers i teixidors que comentem). Tanmateix, amb la incorporació de grups de dones al seguici, a continuació d'aquestes seccions, podrem apreciar un progressiu desplaçament cap a la desfilada literària, parcialment carnavalesca:

[7] els grans senyors amb dones casades; [8] els vidus i vídues; [9] les donzelles i solters; [10] les monges «jóvens e galants se abillaren, e encara moltes de les ansianes se vestiren totes de seda, e cascuna de aquestes portava una candela encesa en la mà»; [11] «totes les dames de la terça regla, no menys vestides de drap de seda burella que les monges, e cascuna portava en la ma un stadal, cantant totes lo Magnificat $\gg ;$ [12] «los officials reals del regne e tots los hòmens armats a peu, axí com si deguessen entrar en batalla...».

I aquesta tendència s'escora i culmina amb una decantació final ja palesament carnavalesca, amb la presència de:

[13] Aprés venien totes les dones públiques e les qui vivien enamorades, e ab tots los rufians qui anaven ab elles. E cascuna portava en lo cap una garlanda de flors o de murta perquè fossen conegudes; e si n'hi havia alguna casada que se'n fos anada del marit havia portar en la mà una petita bandera. E anaven ballant $\mathrm{ab}$ tamborinos.

$\mathrm{Al}$ rerefons de l'episodi del Tirant alenen, doncs, sens dubte, unes pràctiques o costums, les de les processons o desfilades paròdiques a les ciutats medievals ${ }^{24}$. I s'albira una realitat social, la dels menestrals, els artesans que professaven un art mecànic, i s'organitzaven en oficis (després anomenats gremis) ${ }^{25}$. A partir d'ací, Martorell, com reconeix Hauf, es beneficia de l'excusa dels

23. Explica Narbona $(1993,2003,2017)$ com el paper del clergat quedava en un principi limitat a esperar el monarca a la catedral i acompanyar-lo durant les oracions, però a partir de 1439 un dels elements constituents de la grandiloqüent rebuda al rei esdevé la participació del clergat. Des de l'entrada de Joan II i la de la seua esposa, es va propiciar la trobada del seguici cívic amb una processó religiosa encapçalada pel bisbe, en què participaven els canonges de la catedral, el clergat parroquial ordenat, amb les seues creus i una representació de tots els ordes religiosos amb convents en els termes municipals. En una de les places pròximes a la Seu, el monarca es veia obligat a descavalcar, a agenollar-se i a adorar públicament un fragment de l’autèntic Lignum Crucis que li era presentat pel bisbe, després del qual venia la processó religiosa que conduïa caminant fins a la catedral, perquè realitzés les seues oracions davant l'altar major i jurés la legislació foral. A la sortida, de nou era acompanyat pel seguici cívic que l'havia introduit a València i que, després del ritu preceptiu, l’acompanyava a la seua residència. El més notable d’aquesta segona època és l'increment dels elements sobirans concebuts pel municipi per exalçar la monarquia, utilitzant per això una variada gamma de recursos similars a la recepció teatral del portal o al seguici allegòric dels entremesos en la desfilada. La presència del rei es va veure carregada de símbols sobirans en cadascun dels seus actes, des de l'espontani passeig eqüestre amb un reduit grup cortesà per a la visita particular de la ciutat i les seues botigues (proximitat a poble) fins a la concessió de nous privilegis (monarca legislador), i des del regal de relíquies a l'església catedral (exercici de pietat) fins a l'execució d'actes de fe, la presidència de punicions judicials ordinàries, l’aplicació directa de pragmàtiques que fa a l'ordre públic o la concessió de gràcies i perdons (monarca justicier).

24. Per a Oleza (1992), que analitza l’episodi, les tensions i contradiccions entre poders polítics (estatal i urbà) esclaten en la rialla final, quan la desfilada culmina amb el seguici -en un conjunt quasi indiscriminat- de monges i prostitutes.

25. Les xifres d’artesans de València, a partir de documentació de 1347, serien : peraires (347), teixidors (338), sabaters (335), corredors (249), sastres (243), llauradors (243), fusters (196), pescadors (168), blanquers (168), pellissers (131), aluders (116), notaris (114), freners (109), hòmens de mar (93), ferrers (83), corretgers (77), carnicers (71), pellers (60), assaonadors (60), esparters (59), bainers i coltellers (57), argenters (55), flaquers (43), piquers (39), especiers i candelers (33), forners (31), barbers (31), juris- 
brots d'una revolta anàrquica de dos d'aquests gremis per llançar i fer esclatar el coet o la traca de la seua burla:

aprofita per fer petar la broma i introduir una sàtira d'una problemàtica tan ridícula com aleshores de gran actualitat, ja que eren constants, especialment entre els frares, les baralles causades per qüestions de precedència, i per la banal casuística en què hom volia sovint fonamentar la superioritat d'un gremi o estament sobre un altre, que podien acabar a colps de ciris o de creus alçades (Martorell, 2005: 200-201) ${ }^{26}$.

\subsection{Disputes entre oficis}

Naturalment, no trobem entre aquestes descripcions gairebé notarials del Dietari traces d'una baralla semblant a la que es presenta al Tirant. Recordem que els teixidors deien que «no.s podia dir missa ni consegrar lo preciós cors de Jesucrist sens drap de li; e los juristes per part dels ferrés al.legaven que primer fon l'ofici de ferrer que no de texidor, per quant lo teler del texidor no podia ésser fet sens ferramenta». Les excuses són banals i desgavellades, però allò important, que es vol remarcar, és el motiu de la baralla, que no és altre que la preeminència, tot i que igual de trivial: «que primer fon...». El narrador vol remarcar, al capdavall, el fet que aquesta divisió, que podia haver sigut resolta en un tres i no res, és engrandida per incompetència i conveniència pròpia pels juristes embolicadors. I aquest fet, que arriba a causar una revolta popular, sí que significa el principi d'un desplaçament des de la versemblança cap a l'exageració, que es farà definitiu amb la intervenció del duc.

El conflicte entre ferrers i teixidors manté de bestreta una total versemblança, perquè són dos oficis presents en el Consell de València de forma primerenca: des de 1283 formen part dels primers 15 oficis amb dret de tenir-hi consellers propis. I es disputen des del primer moment la prelació a l'hora d'ésser escrits els consellers d'oficis en les actes municipals, en el moment de constitució anual del Consell: en el segle XIV, des de 1306-1309, els teixidors figuren els tercers en la llista, després de notaris i freners, mentre que en canvi els ferrers són els antepenúltims. La cosa canvia en el segle XV; en 1403-1406 els ferrers han passat a ocupar el lloc 7 mentre els teixidors han baixat al lloc 9 en la prelació emprada en la constitució anual del Consell. Com que l'organització de les desfilades permetia disposar els oficis simultàniament a dreta i esquerra del carrer, és possible que teixidors i ferrers trobaren pretextos per bregar, ja que un hauria d'anar darrere de l'altre (Narbona, 1990 i 2016).

Raufast encapçala l'epígraf cinqué i darrer d'un dels seus principals treballs sobre les entrades cerimonials a Barcelona amb una citació llarga, que conté el nucli central de la discòrdia entre els dos oficis de Tirant ${ }^{27}$. L'historiador, a partir de la cita, explica que el passatge de la novel.la seria una excepció - per bé que literària- dins la «imatge» habitual, ideal, harmònica i estable, que de

tes (31), drapers de lli (30), taverners (29), bossers (25), calderers (23), tintorers (21), arquejadors (18), metges (10), canviadors (8) i pilaters (2) (Martínez Vinat, 2018: 190).

26. Com resumeix Hauf, quan anota el passatge: «les processons eren la manifestació pública de l'estructura jeràrquica de la societat medieval, eminentment estamental. [...] Els membres dels gremis de menestrals desfilaven revestits amb les liurees ornades amb les insígnies del seu ofici, tenien també establerta una estricta prelació ben documentada en processons com la del Corpus valencià, que conservaren la seva estructura fins avançat el segle XIX» (Martorell, 2005: 199).

27. El treball incideix en la importància de l'ordre dins el seguici, i en el fet constatat de les baralles entre oficis per la preeminència en aquest ordre. L'epígraf al qual segueix la citació de Tirant porta per títol: «El escenario tensionado: conflictos en torno a la participación de los oficios en las ceremonias urbanes» (Raufast, 2006b: 681-685). També Chiner encapçala el quart dels sis capítols de la 
l'estructura i funcionament de les associacions menestrals i les seues celebracions cíviques urbanes ens ofereixen el textos legislatius, institucionals, i també les cròniques o dietaris. Però una cosa es la «imatge» i altra la realitat, i el que reflexa la novel.la, com interpreta Raufast, es que l'aldarull: «no es ningún hecho excepcional, e incluso es más que probable que el propio autor contemplara o conociera en vida algún episodio semejante a través de su experiencia personal, ya fuera en su cercana Valencia o en las cortes de Alfonso el Magnánimo, en Nápoles, y del príncipe de Viana, en Barcelona $>(2006 \mathrm{~b}: 681)^{28}$.

Efectivament, aquesta mena de divisions amb batussa i baralla entre oficis sí que es van donar a la València de l'època, o a la corona d'Aragó en general, tot i que no exactament entre ferrers i teixidors, i evidentment no tan exagerades ni tan desgavellades en nombre de participants com en la novel.la. Vegem-ne alguns pocs exemples documentals, tot i que els testimonis gràfics són quatre segles posteriors (Fig. 5). A la Tarragona d'inicis del segle XV, ja trobem fortes discrepàncies sorgides entre els hortolans, els ferrers, els sastres i els sabaters de la ciutat al voltant dels llocs de privilegi en la comitiva artesanal present al Corpus. A València, sabaters i blanquers mantingueren un altre pols de tensió pel mateix motiu d'obtenció de la preeminència en la desfilada, com veurem amb més deteniment, en 1458. I botant de segle, els «zurradores» $\mathrm{i}$ «curtidores» de Saragossa només van poder tancar les seues diferències sobre l'ordre de precedència a la processó de Corpus de $1512 \mathrm{amb}$ la intermediació de les autoritats municipals ${ }^{29}$. Els exemples, en fi, es podrien estendre igualment a altres ciutats europees, com ara York, en Anglaterra, on entre 1482 i 1493 sabaters i teixidors van dirimir una inacabable disputa sobre qui havia de mantenir la precedència en la processó de Corpus, i en la qual van arribar a intervenir tant la monarquia com les autoritats de la ciutat (Raufast, 2006b: 283).

biografia de Martorell, «El llarg camí de la misèria» (1993:119) amb una citació del passatge: «Féu posar dues forques ben altes e féu penjar tres juristes en cadascuna...».

28. «Los ejemplos de conflictos y enfrentamientos a causa del lugar ocupado en un desfile procesional son relativamente numerosos, y el cuidado con el que se intentaba prevenirlos o evitarlos es una señal más de la importancia que se concedía al significado de la ordenación escénica de los participantes en dichas celebraciones. Bajo esta premisa, una ceremonia pública será siempre el resultado de la fricción entre un aparente orden colectivo integrador -en tanto que intento de reconstrucción ideal de una realidad-y los intereses diversos y no siempre coincidentes de sus participantes» (Raufast, 2006b: 681-682). A la ciutat de Barcelona Raufast en troba exemples, daquestes tensions, entre consellers i diputats, comerciants i ciutadans honrats, membres de diferents ordes religiosos, etc: «discusiones entre los consellers y los diputados de la Generalitat, a causa de colocación de los porters de esta última institución en cabeza de la comitiva que había de desplazarse hasta la Catedral durante la ceremonia por la muerte de la reina Leonor en 1436; protestas del estamento mercader por no figurar bajo el mismo pendón que los ciudadanos honrados en la hueste de la Ciudad convocada en 1425; o pleitos entre órdenes religiosas -agustinos y carmelitas- originados por la situación respectiva de sus miembros en las procesiones organizadas por la Ciudad» (2006b: 282). Però no, estranyament, almenys durant el segle XVI, entre artesans i menestrals: «En este universo ordenado y, al mismo tiempo, descompuesto, en el que cualquier variación en el ritual celebrativo era susceptible de ser interpretada en términos tanto sociales como políticos, sorprende, sin embargo, no encontrar apenas huellas palpables de conflictividad ceremonial por lo que respecta al estamento artesanal barcelonés» (2006b: 682-683). Tanmateix, a principis del XVI, en 1520, sí que constata la fixació d’un decret per part dels consellers municipals, en què s'estableix un ordre exacte per a cada confraria o ofici a la processó del Corpus, amb la intenció de «cessar tota natura de disordres y diferències que entre los dits officis e confreries se porien seguir per causa de les precedències o graduaments de aquells, segons que en lo passat és stat vist, si present no y era» (Raufast, 2006: 683).

29. Ho recorden Galé (1996-1997: 83) i Raufast (2006b: 682). 


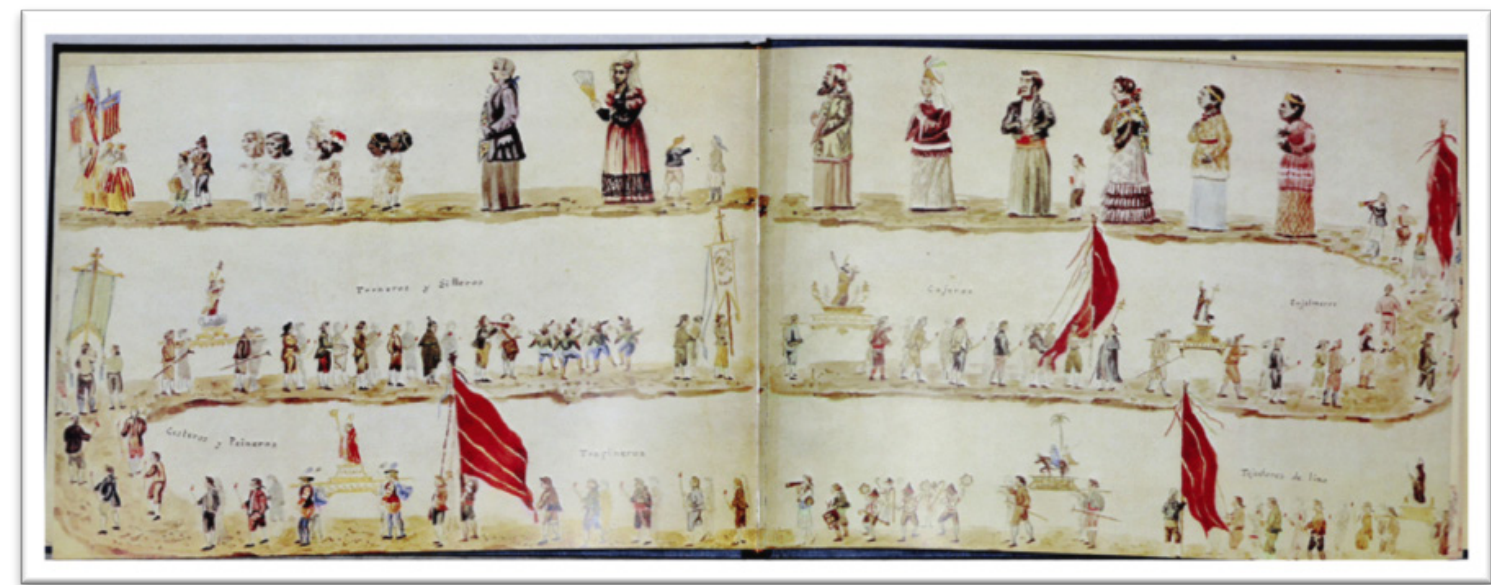

Fig. 5. Processó del Corpus, a València. Rotllo del Corpus (1824)

I encara es poden afegir un altre parell de casos més propers encara a l'episodi del Tirant (per geografia, cronologia i sobretot perquè introdueixen el tercer element en discòrdia: els juristes). Es tracta d'exemples documentats a la ciutat de València i que resulten ben representatius d'una evidència: les disputes entre gremis o confraries eren força habituals i les repercussions podien ser rellevants fins al punt d'arribar a les més altes instàncies, el governador o fins i tot el rei. El primer cas és documentat el 8 d'abril de 1416, a València, on la discussió sobre la «priminència» 0 preferència d'una confraria sobre una altra en una desfilada -«al.legant cascuna de les dites parts deure anar primer e a la mà dreta en la dita solemnitat»- arriba al governador del Regne, Vidal de Blanes. El governador hi dicta sentència establint la «priminència» de la confraria de Sant Jaume sobre la de Santa Maria de la Seu a la desfilada pels funerals de Ferran I d'Aragó. I aquesta «priminència» o precedència és justament el motiu primer, com hem vist, del divís entre ferrers i teixidors a l'episodi del Tirant: «los texidós de li deÿen que devien precehir als ferrés, e los ferrés deÿen lo contrari, que ells devien haver la honor dels texidós $\gg^{30}$.

La decisió del governador es pren oïdes les parts d'ambdues confraries i després de tenir «madura deliberació» $\mathrm{amb}$ «solemnes juristes»; juristes independents de les dues parts: «los quals no són confrares de alguna de les dites confraries». El dictamen és favorable a la confraria de Sant Jaume: «haver priminència de anar e star primers e a la mà dreta en la dita solemnitat». Aquesta resolució va intentar ser apel.lada per la confraria perdedora (la de Santa Maria), amb recurs desestimat (Martínez Vinat, 2018: 1111-1112) ${ }^{31}$.

30. Com assenyala Raufast: «Los ejemplos de conflictos y enfrentamientos a causa del lugar ocupado en un desfile procesional son relativamente numerosos, y el cuidado con el que se intentaba prevenirlos o evitarlos es una señal más de la importancia que se concedía al significado de la ordenación escénica de los participantes en dichas celebraciones. Bajo esta premisa, una ceremonia pública será siempre el resultado de la fricción entre un aparente orden colectivo integrador - en tanto que intento de reconstrucción ideal de una realidad-y los intereses diversos y no siempre coincidentes de sus participantes» (2006b: 682).

31. «E lo dit honorable governador, ohits aquells e hauda madura deliberació ab solemnes juristes, los quals no són confrares de alguna de les dites confraries. E presents les dites parts, e presents encara los honorables batle general de regne de València, e mossén Domingo Mascó, e en Manuel de Montagut, jurat de la dita ciutat. E de mi, Pere Vicent, notari e scrivà de la dita cort, e dels testimonis dejús scrits. Sentencialment pronuncia e declara de paraula e ab la present mana per molts sguars los prior, maiordòmens e confrares de la dita loable confraria de Déu e de madona Santa Maria e de Sent Jacme, e creu llur, ésser e anar e haver priminència de anar e star primers e a la mà dreta en la dita solemnitat. E los dits prior e maiordòmens e confrares de la dita loable confraria de Sancta Maria e creu llur, anar e star aprés e a la mà squerra. Manant ab la present a aquells e cascun de aquells que sots pena de cinch milia florins $\mathrm{d}$ 'or 
Però un document encara més revelador i més proper al temps d'escriptura de Tirant lo Blanc seria el referit a una disputa entre blanquers ('assaonadors de pells') i sabaters, que podem trobar -gràcies a la recerca documental de Martínez Vinat-, signat el 3 de maig de 1458 a Terol. En lletra enviada per Joan de Navarra -llavors encara lloctinent general del seu germà, el rei Alfons el Magnànim (el rei Alfons mor a penes un mes després, el 27 de juny)-, a Berenguer Mercader, batlle general de València, aquest és instat a resoldre la causa existent entre aquests dos oficis (blanquers i sabaters) de la ciutat de València, per damunt de totes les provisions i privilegis realitzats fins aquesta data en aquest plet.

Els precedents que fan que el rei de Navarra escriga al batlle de València tenen a veure directament amb «la qüestió e debat que és entre los officis de blanqués [...] de la una part e los sabaters de la altra part $\gg^{32}$. No són ferrers i teixidors, i no sabem quines serien exactament les raons de la disputa, però la dissensió plantejada («la qüestió e debat que és entre los officis...») és de semblants dimensions que la de la novel.la, i tan escandalosa i greu que arriba fins al rei de Navarra, aleshores lloctinent del Regne. La resolució diu que, per bé general («per major contentament de totes les parts»), el germà del rei li dona poders al batlle, Berenguer Mercader, per a examinar el cas de la disputa i donar-li resolució justa («façats e ministrats en lo dit fet ab totes les circumstàncies de aquell degut compliment de justícia»), sense -i aquesta és la part que ens interessa remarcar- que «les dites parts no perdan son temps anant per corts e juristes, despenent ço del seu inútilment $\gg^{33}$.

És a dir, se li dona plena potestat -«donant en tot aquell bon recapte que de vostra bona indústria confiam...»- a Berenguer Mercader per a resoldre la causa, i se li ofereix llibertat absoluta per evitar les dilacions que poden venir de la intervenció de «corts e juristes». Els juristes s'associen clarament, en aquest cas, amb els entrebancs i l'endarreriment en la resolució de casos en conflicte («no perdan son temps»), i amb les despeses inútils dels litigants («despenent ço del seu inútilment»). Suposen el contrari de la confiança i el seny («bon recapte»), i l'efectivitat («bona indústria») que representaria la bona burocràcia municipal. La paraula de la secretaria d'un rei (el rei Joan de Navarra, pocs mesos després rei d'Aragó) desacredita d'aquesta forma extraordinàriament insòlita la diligència -i per tant la capacitat- dels juristes per a resoldre un cas de «qüestió e debat» entre els oficis de blanquers i sabaters. Pense, doncs, que estem davant del

sien e entrevinguen en la dita solemnitat del dit jorn de demà en la manera e grau dessús dits, bé e honradament, segons en semblants solemnitats és acostumat» (Martínez Vinat, 2018: 1111-1112).

32. I s'exposa de la següent manera: «Magnífich e amat conseller del senyor rey e nostre, aprés que últimament vos havem scrit sobre la qüestió e debat que és entre los officis de blanqués de aqueixa ciudat de la una part, e los çabaters de la part altra, són stats ab nós los qui eren tramesos a nós per los dits blanquers, per los quals nos són stats exhibits lo privilegi e altres letres e provisions del senyor rey e de aquexa ciutat obtengudes, suplicant-nos ab molt grant instància que-ns plagués donar los nostres letres executòries del dit privilegi real e altres provisions oportunes, ço que havem recusat fer sabent la diversitat de les provisions que per lo senyor rey són stades atorgades en favor dels uns e dels altres, e encara no ignorant que per la sua majestat aquest fet és stat remés a vos, atenent maiorment que.s preten que açò redundaria en derogació e diminució dels drets e regalies del dit senyor rey...» (Martínez Vinat, 2018: 1081-1082).

33. «...havem deliberat, remetrén tot a vos, pregant e encarregant-vos, axí stretament com podem, que per major contentament de totes les parts, vetats ab los del consell del senyor rey tots los privilegis, letres e provisions e drets de cascuna de les dites parts, e aquells on d'es façats e ministrats en lo dit fet ab totes les circumstàncies de aquell degut compliment de justícia, iuxta la voluntat e ordinació del dit senyor rey, per forma e manera que en aquesta causa sia donada fi e conclusió, e les dites parts no perdan son temps anant per corts e juristes, despenent ço del seu inútilment, donant en tot aquell bon recapte que de vostra bona indústria confiam, car ultra que és servey del senyor rey que axí.s faça ne reportaren mèrit e confirmació de vostra bona reputació. Dada en Terol a III dies de maig de l'any MCCCCLVIII. El rey Johan. / Al magnífich e amat conseller del senyor rey e nostre mossén Berenguer Mercader, batle general del regne de València» (Martínez Vinat, 2018: 1082). 
document notarial i històric més proper a l'inici o punt de partida de l'episodi de disputa fictícia o «divís» entre «oficis» que presenta la nostra novel.la. El document confirma que la desconfiança en l'efectivitat dels juristes no és simplement una queixa banal o un tòpic vulgar.

\section{Les crítiques als juristes}

\subsection{Recomanacions per a la reducció dels juristes}

En la Baixa Edat Mitjana, la professió de jurista era absolutament imprescindible dins les administracions locals, senyorials i reials, organitzades d'acord amb un Dret romà reformulat de diverses maneres, habitualment segons la tradició de l'escola bolonyesa. La jurídica era, a més a més, sens dubte, una bona, si no la millor professió per tal d'aconseguir promocionar socialment al caliu d'aquestes administracions (Puchades, 1999: 61). La funció específica del jurista en un plet era al.legar els motius i raons en contra o a favor de la lliure absolució del processat. Però, com diu Puchades: «Justament era la complexitat i la duració que assolien els processos [...], el que portava a la resta de la població no versada en el dret romà a veure el jurista com una estranya combinació d'intel-lectual especialment culte i de professional amoral que s'aprofitava de la ignorància dels altres» (1999: 70).

El document examinat en l'apartat anterior $(\$ 3.2)$ no és excepcional en allò que conté de crítica oberta a la inoperància dels juristes, sinó en el fet que associa l'aplicació d'aquesta manca d'efectivitat al cas concret d'una disputa entre menestrals. El cas documentat no justifica, és clar, però sí que palesa una certa harmonia amb la decisió del duc de Lencastre (ratificada pel rei anglés):

fésseu en vostre regne que no y agués sinó dos juristes, e aquells dins $\mathrm{X}$ o XV dies aguessen determenada qualsevulla causa ab sentència diffinitiva, e dar-los bon salari a cascú. $\mathrm{E}$ si prenien res de negú, que no agen altra pena sinó aquesta que havem executada.

Aquesta proposta del duc i del rei podia semblar fonamentada, com anota Hauf en la seua edició, «en una constant recomanació de Fra Francesc Eiximenis» al voltant de la reducció de juristes. Efectivament, al cap. 28 del Regiment de la cosa pública, dedicat als jurats valencians -i que correspon al c. 384 del Dotzè del cristià, «Qui posa com multiplicació de juristes nou molt a la cosa pública» (Hauf, 1983: 217-219)-, Eiximenis defensa que la justícia és un dret del poble i una obligació reial, i proposa com a model d'expeditesa el sistema d'administració de justícia musulmà, alhora que ataca les tècniques dilatòries dels advocats:

Per bon estament de la cosa pública deu hom esquivar que no s'hi multipliquen molts juristes ne advocats. Car aquests atals [...] han a prendre grans salaris de llurs advocacions e han a tenir grans maneres a tractar les causes a llurs profits, així com és dar grans dilacions en les causes, puntejar agudament e supèrflua en ço que és clar, emparar molts negocis e espatxar-ne pocs. Per les quals coses la gent e la comunitat sostenen grans càrrecs, e a la fi és la cosa importable... Los tirans en Itàlia així mateix fan espatxadament les causes determinar... (Hauf, ed., 2004: 201-202).

Les crítiques a juristes i advocats (i lletrats en general) s'havien donat i es continuaran donant sempre, tot proporcionant matèria més o menys tòpica a la literatura. El rebuig popular, i també cavalleresc, dels juristes és una constant literària per tot arreu. I el Regne de València no hi era una 
excepció. Rubio Vela aporta un document, signat l'any 1399, presentat al rei pels jurats de València, que parla que «tota vostra terra crida que advocats juristes la devoren, e aquesta clamor no és de prop, ans és de luny, de mil anys, de què proceí lo vulgar e antich proverbi: Draps de França e libres de Bolunya / consumen Aragó e tota Cathalunya» (1985: 117-120) ${ }^{34}$.

Tanmateix, l'ofici de jurista, l'ofici de Ciceró o de Tomàs d'Aquino, no podia estar mal vist, en termes absoluts, ni pels jurats ni per Eiximenis, qui considerava la professió, junt amb la dels metges, notaris o mercaders, com una de les arts lucratives, no sols necessària, sinó digna de tota consideració $^{35}$. Com matisa Puchades i Bataller: «el desprestigi moral del jurista, derivat de les irregularitats en el desenvolupament de les seues funcions, no implicava un desprestigi social equiparable...» (1999: 74). En determinades ocasions, els juristes valencians s'alçaren contra la monarquia i suportaren duríssimes penes, i fins i tot foren condemnats a mort per defensar causes legítimes, però contràries als interessos del poder dominant, com ara en el cas de la Unió de València (a mitjans del segle XIV) o de les Germanies, a inicis del XVI. Graullera (2009) ha estudiat perfectament el paper de cadascú dels juristes valencians que es troben documentats al segle XV, aportant-ne una nòmina de més de dos-cents. Molts d'ells, personatges rellevants de la història i la cultura de València, com ara Pere Joan Belluga, Bonifaci Ferrer (germà de sant Vicent Ferrer), Lluís Crepí de Valldaura, Miquel Dalmau, Domènech Mascó (Micer Mascó) i tants d'altres, entre moltes importants personalitats. En parlarem després d'un, Gabriel Riusech, per la seua relació amb la família dels Martorell, però evidentment la família, i Joanot, tingueren relació amb diversos altres bons juristes.

Fet i fet, els continguts principals de la ideologia propugnada justament per Eiximenis per al govern de les ciutats -inclòs el paper d'aquests professionals qualificats al costat del patriarcat urbà- van ser dissolts a poc a poc pels regnats Trastàmara, que van iniciar un progressiu procés de centralització estatalista i control polític dels municipis. Com explica Narbona: «Al patriciado urbano no le quedaba más remedio que transformarse en el portavoz local de la monarquía y, según los nuevos presupuestos ideológicos, la cosa pública quedaba a su servicio por encima de la comunidad» $(1993: 470)^{36}$.

\subsection{L'experiència de Martorell amb el jurista Riusech}

A la vida real, Martorell hagué de combatre, és clar, amb la burocràcia i a vegades amb els juristes que defensaven els interessos dels contraris. Però també va haver de recórrer, com és natural, a juristes i advocats com a aliats i defensors de les seues causes. En la documentació presentada per Chiner i Villalmanzo, els juristes estan presents quan es requereix la seua intervenció, sobretot en moments crítics de venda de senyorius -els de la Marina Alta- dels quals la família Martorell s'hagué de desprendre (Chiner, 1993: 97-151; Villalmanzo, 1995: 156-161). El jurista Gabriel Riusech hi destaca, en aquells moments i anys. Riquer ja va detectar la presència extravagant d'un

34. Vegeu una àmplia explicació, ben contextualitzada, de Puchades i Bataller (1999: 72-73).

35. Per a Eiximenis: «La quarta manera de guanyar diners s’apella artíffica. E aquesta és saber guanyar diners per alguna art lucrativa, o per offici temporal de senyor o de comunitat. Les arts lucratives, més que altres, són art de jurista, de metges, de cambiador, de monader, de mercader e de notari... « (apud Cruselles, 2017: 290).

36. La mediatització política i institucional imposada pel regalisme sobre l’oligarquia (Racional municipal, Virreis, Capitans Generals, Mestre Racional del Regne) la convertia en una simple gestora del bé públic. Com resumeix Narbona: «En época moderna se culminaría el proceso, ya que se compactarían las fuerzas sociales en torno al estado, separando completamente a la sociedad de la gestión de lo político y, en consecuencia, decrecería su papel en las manifestaciones festivas de la soberanía real» (1993: 470). Oleza (1992), quan estudia aquests capítols del Tirant, constata com s'hi produeix la substitució del poder ciutadà pel poder del rei. 
Albert de Riusech dins el grup de vint-i-cinc cavallers elets de la Garrotera, on hem vist el duc de Lencastre. Aquest Riusech podria correspondre a un record -un gest de complicitat- amb el Gabriel de Riusech documentat per Villalmanzo. A més a més, Rubio Vela (2010: 73-74) i, després, amb nova documentació, Escartí (2012) associen també aquest Gabriel de Riusech amb el jurista que apareix com a procurador del comtat de Dénia junt amb Joan Martorell -que els dos historiadors identifiquen amb el Joanot Martorell novel.lista-. Segons aquesta identificació, tots dos, Martorell i Riusech, haurien mantingut conjuntament i complementàriament el comtat de Dénia. Martorell hauria sigut el «braç executor», que hauria hagut d'actuar tot tenint en compte els consells del jurista Riusech, expert en qüestions judicials: «mossén Johan Martorell haja a regir e procehir a consell del dit micer Gabriel, lo qual volen sia asessor a aquell». Com diu Escartí:

I així, mentre Martorell, home bregós i enèrgic, seria el braç executor de la justícia comtal a les terres de l'estat de Dénia, Riusech seria l'encarregat de vigilar que tot es realitzàs d'acord amb la llei. Una funció, la de Riusech, que no era la primera vegada que l'exercia, en haver d'intervenir com expert en lleis en conflictes, com ens consta que va ocórrer en altres casos (2012: 395).

Tot i que la identificació d'aquest Joan Martorell, procurador del comtat de Dénia, amb Joanot Martorell és ara per ara difícil de demostrar -com ja va assenyalar fa uns anys Ferrando ${ }^{37}$-, hem volgut recordar-la perquè, com que resulta si més no versemblant, ajuda a entendre l'ambigüitat de relacions entre un cavaller -encara que no fos l'autor de Tirant- $\mathrm{i}$ un jurista. Tots dos es necessiten mútuament: s'ajuden, es fan costat i segurament també es temen i fins i tot arriben a odiar-se l'un a l'altre.

\subsection{Altres referències als juristes del Tirant}

Allò que avui anomenaríem i multiplicació funcionarial excessiva (a més d'endogàmia professional, prevaricació, etc.) rep, en el cas dels juristes, una dura crítica per part dels intel.lectuals compromesos com Eiximenis, i fins i tot sàtires als exempla moralitzants. Ningú, però, no posa seriosament en dubte la seua necessitat per al bé del regiment comú. I aquesta lectura ambigua del paper de la professió de jurista es manté dins la mateixa novel-la. Per això els juristes apareixen positivament en boca de l'Emperadriu, dins la discussió entre Saviesa i Ardiment del capítol 182:

Per què dich que saviesa no deu ésser acomparada ab ardiment. ¿No sabeu per a qui fa la saviesa? Per a ciutadans e juristes, qui han a regir les comunitats e administrar la justícia. Aquests tals ab la saviesa treballen contínuament en fer viure a si mateix e a la popular gent en repòs, squivant com poden tota manera de guerra (Martorell, 2004: 770).

Positivament, sí, però situats en un camp diametralment oposat al dels cavallers, com expressa ben palesament unes línies abans la mateixa Emperadriu:

37. Com conclou Ferrando: «La recerca de Rubio Vela permet constatar uns vincles estrets entre l'autor del TB, els Sandoval i la cort de Joan d’Aragó / Joan II. La seua hipòtesi, defensada amb molta convicció [...], no ens forneix, però, proves suficients per a demostrar que mossèn Joan Martorell, procurador de Dénia, és identificable amb l’autor de TB. Tanmateix, aporta observacions útils per a situar el TB en el seu context històric i cultural» (2012: 654). 
E dich, primerament, que saviesa no déu esser dada als cavallers, car negun cavaller qui savi sia no pot fer negun bon fet honorós, car pensa en lo gran perill que és en les armes e contempla tots los inconvenients que seguir-se'n poden: pert lo ànimo de empendre res que de honor sia, qui ab perill s'haja atényer, ans és hun grant covart (Martorell, 2004: $770)^{38}$.

I poc després, en el cap. 185, l'Emperador es troba amb una discussió que aparenta un greu dilema, encara que en realitat es tracta d'una situació igualment artificiosa que l'anterior. L'Emperador aplega els membres del seu consell. I en el consell «hagué ... grans altercacions», disputes i es va fer palesa la impossible concòrdia entre cavallers i juristes:

L'emperador ixqué de aquella cambra e entrà-se'n en una altra, e aplegà consell de cavallers e de juristes, e hagué en lo consell de grans altercacions, que molts tenien la part de ardiment, los altres de saviesa, e aquí disputaren molt e no.s podien concordar (Martorell, 2004: 777).

Els cavallers optaven òbviament per defensar Ardiment i els juristes, amb la mateixa lògica, per defensar Saviesa, en posicions tan maniqueament polaritzades com les de l'altercatio o debat clàssic medieval entre el cavaller i el clergue, el pa i el vi, etc. Aquestes «altercacions», absolutament retòriques, com acabem de comentar, ens recorden el «divís» entre ferrers i teixidors. I ens fan pensar, de nou, en l'artificiositat de la baralla entre oficis presentada.

\section{Ferrers i teixidors: entre la processó religiosa i la carnavalesca}

Hem parlat fins ara específicament de la participació dels gremis a les entrades reials, però hem de tenir en compte també la participació en les processons religioses, com ara la del Diumenge de Rams o la del Corpus. Processons en les quals cada confraria hi era present amb exhibicions grupals de forma coherent i diferenciada, relacionada amb les característiques de l'ofici (la Santa Cena per als forners, les xarxes de pesca per als pescaters, etc.). Aquesta combinació i fusió, a l'hora de la representació simbòlica, d'elements professionals i de la històrica religiosa, havia de tenir present també tot un imaginari folklòric associat, d'una banda, al rerefons mitològic i llegendari, i d'altra al paper de determinats personatges i oficis en l'antic i el nou Testament, i en la història del cristianisme després de la mort de Jesús.

Ferrers i teixidors compten amb una tradició folklòrica que es podria prestar a la representació popular, tot i que aquesta tradició no sembla més rica que la d'altres oficis, com ara forner, fuster, moliner (o molinera), etc. El ferrer arrossega el lligam mític amb Hefest o Vulcà i, a més a més, la farga de Vulcà donaria «déus» menors o, millor, humans una mica pretensiosos, com ara els protagonistes de les rondalles sobre el ferrer que burla el Diable (ATU, 330, The Smith and the Devil), molt populars en català i en terres hispàniques. Pel que fa als teixidors, dins els tipus de rondalles internacionals -sempre amb representació en català o hispànica- en podem trobar de covards (Aa-Th, 1854*); més sovint de valents, com el famós ATU, 1640, The Brave Taylor; o d'espavilats

38. Es tracta d'una discussió artificial, un exercici de controvèrsia oratòria i d'un debat sobre dones, més que no entre dones (Cantavella, 2003), on l'Emperadriu, per exemple, parla defenent una posició - el mateix que podia haver defés la contrària - amb una sensatesa i coherència que desmentirà després el seu comportament lleuger amb Hipòlit. Per a una aproximació i resum del tema d’aquestes questiones sobre i entre dones al Tirant, vegeu Beltran (2006a: 229-232). 
o tricksters, com els protagonistes d'ATU, 1620, The Emperor's New Clothes, rondalla present a la tradició castellana des de l'exemple núm. 32 d'El conde Lucanor de don Juan Manuel.

Hem de tenir presents tots aquests elements d'«imaginari» (en el sentit interdisciplinari en què l'entén Massip), donat que des del punt de vista de la lògica o de la congruència, l'argument de prioritat dels teixidors - «que no.s podia dir missa ni consegrar lo preciós cors de Jesucrist sens drap de li $>-$ no se sosté. Ni tampoc no en té, de fonament o sentit, l'excusa dels ferrers: «que primer fon l'ofici de ferrer que no de texidor, per quant lo teler del texidor no podia ésser fet sens ferramenta». L'associació del cos de Jesucrist amb la delicadesa del lli prové remotament de l'evangeli de Joan, 19, 40: «Llavors van prendre el cos de Jesús, i ho van embolicar en teles de lli amb les espècies aromàtiques». Els teixidors de lli no es diferenciaven encara, com ho farien més endavant, d'altres teixidors, com els de llana. Però és cert que en trobem, de teixidors, a la documentació medieval, teixint «draps de li» per als altars, o els mateixos «draps de li» cobrint missals o altres peces delicades. I també és cert que els ferrers s'aprofitaven del seu ofici metal.lúrgic fonamental per tal de traure'n avantatges. Però no hi podem anar més enllà. Totes plegades, les dues al.legacions, tan formals («causa»; «al.legació», terme jurídic que es repeteix), senzillament fan gràcia per banals i absurdes. Com tractarem de justificar $(\$ 6)$, formarien part d'una simple baralla o concurs dialèctic o argumental -rethorical contest- entre babaus (o llestos, o hàbils mentiders), per veure qui en diu de més grosses, d'exageracions o mentides.

Fet i fet, és difícil trobar en discussió els membres de la parella «teixidor»- «ferrer» en la literatura, tradicional o no. A l'episodi del Tirant podien haver sigut, doncs, altres representants d'altres oficis, com ara sabaters, tapiners o fusters, els qui hagueren començat l'aldarull de la discòrdia. Tanmateix, sí que tenim notícies de roques representades pels gremis, tant de teixidors de lli, com de ferrers, però hem d'esperar fins al segle XVIII per documentar-les, i en concret fins a la desfilada que es va fer a València per celebrar la proclamació com a rei d'Espanya de Carles III, en 1759. Hi desfilaren els teixidors de lli amb una graciosa escena de Santa Anna amb la Verge de menuda, cosint ( haciendo canilla») $)^{39}$ (Fig. 6). I els ferrers, amb tota una ferreria en dansa, sobre una roca ${ }^{40}$.

39. Oller y Bono: «Los Texedores de Lino, despues de Estandarte, Vandera, y Guion, que entre sì competian en lo rico, llevavan su Carro Triunfal, ocupado en su assiento de dos jovenes en trage de Reyes, que representavan à los de España, con un Indio a los pies con varios trofeos de guerra en las manos. Mas abaxo havia un telar, y una Matrona tegiendo lienzo, que representava à Santa Ana, y una Niña haciendo canillas ['cosint': les 'canelles' són canotets per a cabdellar fil]. Esta era tan agraciada, como era menester, para ser figura de Maria en su niñez. Las dos regalavan liberales al Pueblo con pedaços de lienzo, y un Angelito con tegidos de las glorias de nuestros Reyes en poesias bien hiladas» (1759: 55). Lescena de Santa Anna ensenyant la Verge a cosir no és la més habitual dins la iconografia de la parella (normalment l'ensenya a llegir), però tampoc no és excepcional (Fig. 6).

40. Oller y Bono: «Los Herreros, Herradores, y Albeytares, à mas de un hermoso Estandarte, y una Santa Lucía de muy buena vista en ombros de Volantes, que iva honrada de doce hachas, y doce ciriales, sacaron una Herrería andante, donde muy de asiento trabajavan algunos del Oficio. Ella estava en el foro de un Carro en que el arrayan, y aun las flores, se mostraban imarcesibles al calor, y humo de la fragua» (1759: 55) 


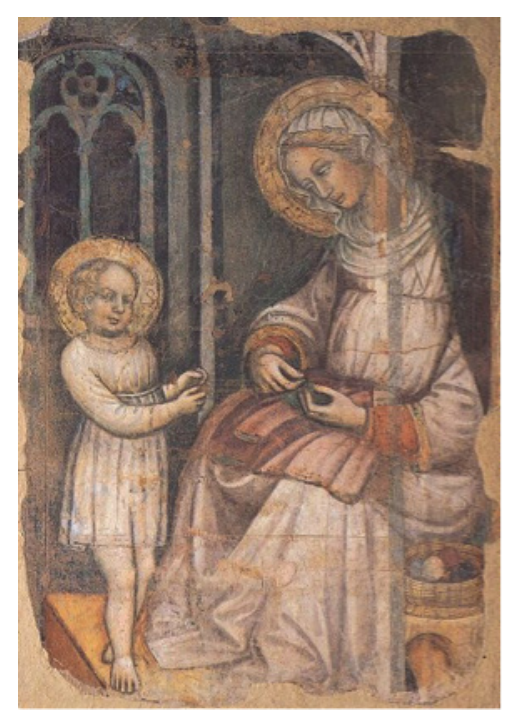

Fig. 6. Santa Anna ensenyant la Verge a cosir.

Fresc del 'Mestre del Bambino Vispo'. Museo della Santa Croce. Florència

Sense haver fet una recerca exhaustiva, només trobe aquesta parella «teixidor $\gg-\ll$ ferrer» en unes pàgines de l'inesgotable Quijote, però a més a més presentada en un context divertit, i precisament de tradició folklòrica i, a sobre, carnavalesca. Quan Sancho està acabant el seu període de governació a l’«ínsula» Barataria, té un incident amb un xic («mozo»), perseguit per la justícia, que paga la pena reproduir:

Y en esto llegó un corchete que traía asido a un mozo y dijo:

-Señor gobernador, este mancebo venía hacia nosotros, y así como columbró la justicia, volvió las espaldas y comenzó a correr como un gamo: señal que debe de ser algún delincuente; yo partí tras él, y si no fuera porque tropezó y cayó, no le alcanzara jamás. -¿Por qué huías, hombre? -preguntó Sancho.

A lo que el mozo respondió:

-Señor, por escusar de responder a las muchas preguntas que las justicias hacen.

- ¿Qué oficio tienes?

-Tejedor.

- ¿Y qué tejes?

-Hierros de lanzas, con licencia buena de vuestra merced.

-¿Graciosico me sois? ¿De chocarrero os picáis? ¡Está bien! ¿Y adónde íbades ahora?

-Señor, a tomar el aire.

$-i Y$ adónde se toma el aire en esta ínsula?

-Adonde sopla (Quijote, II, XLIX; Cervantes, 1998: 1027-1028).

El noi diu que té l'ofici de «tejedor», però teixeix «hierros de lanza». No he trobat cap explicació crítica per a aquesta excusa del «mosso», tot i que la nota de l’edició darrera diu que és possible que l'expressió tinga un doble sentit eròtic. Si recapitulem un poc, el jove no és necessàriament un delinqüent, però sembla ser-ho, per als «corchetes», donat que fuig. I, una vegada agafat, diu que fuig de la justícia, però no perquè siga un lladre o criminal, sinó per evitar el seu interrogatori (que no és el mateix): «por escusar de responder a las muchas preguntas que las 
justicias hacen». Les respostes incongruents són habituals de molts contes, però aquestes són críptiques. Evidentment, el seu discurs no és el «congruent» de la justícia. El noi «graciosico» o «chocarrero» podria obeir al tipus «estàtic» del llest de les rondalles, però també al tipus del «foll» carnavalesc, tal com el va interpretar en aquest cas Augustin Redondo (1978). He transcrit la continuació del passatge, perquè continua amb altra resposta incongruent $(\ll-i Y$ adónde se toma el aire en esta ínsula? -Adonde sopla»), que tanmateix Redondo relaciona directament amb els temes de carnaval. Com diu el mateix crític:

a los tejedores e hilanderas se les atribuía un saber y un poder mágicos, dado que los hilos de la vida humana se hallan presos en una trama de relaciones e influencias que semeja la urdimbre de un tejido. Por ello, se prohibía hilar durante las Carnestolendas, época de $\ll$ locura», para no correr el riesgo de atar los vientos e imposibilitar la circulación del Soplo, así como para no provocar otras perturbaciones con relación al destino de los hombres. Semejantes prohibiciones existieron en Cataluña, Asturias y Castilla (Redondo, 1978: $62-63)^{41}$.

El context de la processó cívica o entrada reial ens pot fer creure que s'al.ludeix a una escenificació més o menys teatral de tots dos gremis. Precedents històrics molt propers en el temps en tenim. Pensem en l'entrada a València, abans comentada ( $\$ 3.1)$, del rei Joan, de 1459 , amb la desfilada dels carnissers portant el bou, els llauradors fent coses de riure, els ferrers amb espases desembeinades, els forners escenificant el «bel entremés» de la Santa Cena, els pellissers amb un jove fent divertiments, els vuit moms amb carasses, encapçalats per un frare predicador i ballador que va parlar al rei «a la francesa», etc.

També afavoririen la idea d'escenificació teatral el fet de la processó dins els mateixos capítols de Tirant, donat que, com hem vist (\$3.1), la desfilada comença de manera aparentment seriosa, però després es desboca i es deixa anar ja totalment amb la presència final, just a continuació de les menoretes (dominiques i clarisses) de les «dones públiques» ballant amb els seus corresponents rufians.

Hem parlat sempre de desfilades civils, urbanes. Però potser Martorell va tractar de confondre ací, al final de la processó, elements de paròdia literària de la processó religiosa del Diumenge de Rams, que tenim documentada a la nostra corona d'ençà de la «consueta» de Tortosa, datada cap a 1430. Martorell podria haver aprofitat la realitat de les processons del Corpus, ben conegudes a la corona d'Aragó des de $c .1320$ i a València, des de 1355 (Baldrich, 1998: 15-20), per a introduir elements trets de les paròdies d'aquesta Processó de Rams (derivades de debats entre el clergue i el cavaller com el de Phillis et Flora, dins els Carmina burana) que, com estudia Félix Lecoy per al Libro de buen amor de Juan Ruiz, comptava amb elements carnavalescos ${ }^{42}$. La processó del Libro de buen amor de Juan Ruiz, arxipreste d'Hita, reflecteix l'entrada de don Amor, després de la Quaresma, amb una fastuosa desfilada en la qual participen tota mena de clergues i ordes

41.És probable que el conte de Cervantes estiguera inspirat en un altre de Juan de Arguijo, com assenyala Chevalier (1975: 310-311; 1978: 104-105).

42. L'episodi total de la «Batalla entre don Carnal y dona Cuaresma» és literari: la «Bataille de Carnage et Câreme». Pero, tot referint-se a la part final de la desfilada del «Trunfo de don Amor» en l'obra de Juan Ruiz, larxipreste d'Hita, diu Lecoy: «Le cortège que nous décrit Juan Ruiz n'est pas un cortège triomphal, c'est une parodie de procession liturgique, et probablement même de la procession la plus ancienne du rite-chrétien, la procession des Rameaux (261). [...] Quant à la procession elle-même, elle est composée d'un certain nombre d’ordres religieux. Où Juan Ruiz a-t-il pris cette idée? Il faut penser, je crois, à la littérature satirique contemporaine» (1938: 261-262). 
religiosos, ordes de predicadors (de sant Pau, sant Francesc, sant Agustí, trinitaris, carmelites, mercedaris...), tots cantant Exultemus i Laudamus. I la processó culmina amb:

Todas dueñas de orden, las blancas e las prietas, de Çistel, predicaderas ['dominicas'] e muchas menoretas ['clarisas'], todas salen cantando, diziendo chanzonetas:

«Mane nobiscum, Domine!, que tañe a conpletas»

(Ruiz, 1990: 535; estr. 1241).

Dones cantant cants litúrgics, paròdics, és clar, donat el context, el mateix que en Tirant hem vist, al final de la desfilada, just abans de les prostitutes, les dones de la «terça regla», és a dir, terciàries o membres de terceres ordes, com ara dominiques [ $c f$. les «predicaderas» de Juan Ruiz] o clarisses $[c f . \ll$ menoretas $)]$ : «totes les dames de la terça regla, no menys vestides de drap de seda burella que les monges, e cascuna portava en la ma un stadal, cantant totes lo Magnificat» (Martorell, cap. 42; 2004: 203) ${ }^{43}$. El Magnificat, ací, remet al càntic del Salm 135; però també se'n fa referència al Tirant, abans, en un somni del rei d'Anglaterra, que conté totes les connotacions del Magnificat de l'Anunciació de l'Evangeli de Lucas, 1, 46-55. Fet i fet, tota l'advertència anterior a aquesta citació, quan l'autor aclareix que «lo rey havia obtesa lisènçia del papa que qualsevolgués monja que stigués en religió streta [...] podia star fora del monestir, e podien vestir de seda», és una mostra humorística més, naturalment, que no tindria cap sentit si no fos dins d'aquest ambient paròdic o carnavalesc.

Una entrada en la ciutat de Tarragona el 9 de juliol de 1514 del nou arquebisbe, Alfons d'Aragó, ens pot ajudar a entendre la simbiosi que es dona -dins els espectacles urbans en què participaven els oficis de menestrals-, entre elements de recepció civil i litúrgica, és a dir, profans i religiosos (Bertran, 2017). A la cerimònia actuaren, després d'un primer ball, teixidors, pagesos, paraires, pescadors, corders, bastaixos, macips, sabaters, forners, sastres, ferrers i fusters, més un «ball de negres». Hi destaquen quatre entremesos, i ens en crida l'atenció, en relació amb el nostre estudi, els preparats per teixidors i ferrers. L'actuació de la primera confraria, la dels teixidors, venia darrere d'un grup de quaranta-quatre minyons d'escola que realitzaven un ball. La relació conservada de la desfilada diu: $\ll[\ldots]$ los de la confraria de St. Miquel que eren los texidos feyen St. Miquel e los angels e los Diables batallaren [...]». I comenta Bertran, en analitzar el document, que es tractava «de la pervivència de l'entremès medieval de Sant Miquel o l'infern, documentat a la ciutat de Tarragona des de 1426. [...] L'ús del mot 'batallaren' permet comprendre el manteniment dels moviments dramatúrgics propis de l'entremès medieval preexistent» (2017: 75). No cal dir que la figura de sant Miquel en lluita contra els dimonis s'ha mantingut com a roca en la processó del Corpus, a València, des de 1542, quan una Roca del Juí Final va ser construïda, dedicada a sant Miquel Arcàngel, en record de la conquesta de la ciutat per Jaume I en 1238. Sant Miquel, a més de guerrer, és jutge i porta en moltes representacions en la mà dreta l'espasa i en l'esquerra la balança del Judici Final (Fig. 7$)^{44}$.

43. L'«estadal» (del llatí statuale, 'ciri fet a mida d'una estàtua votiva') és una candela prima i molt llarga, com les que es porten a les processons o dins els salons d'un palau (cf. Tirant, c. 42: «Stephania venia ab un stadal encés per no portar molta llum, e venia al nostre llit»).

44. L'escultura de Sant Miguel de 1242 portava un escut amb el seu lema característic, les lletres Q.S.D. (Quis sicut Deus?) com a sigles representatives de la pregunta retòrica; portava a la seua dreta l’ànima bona i a l'esquerra la condemnada (Bueno, 2016: 62). 


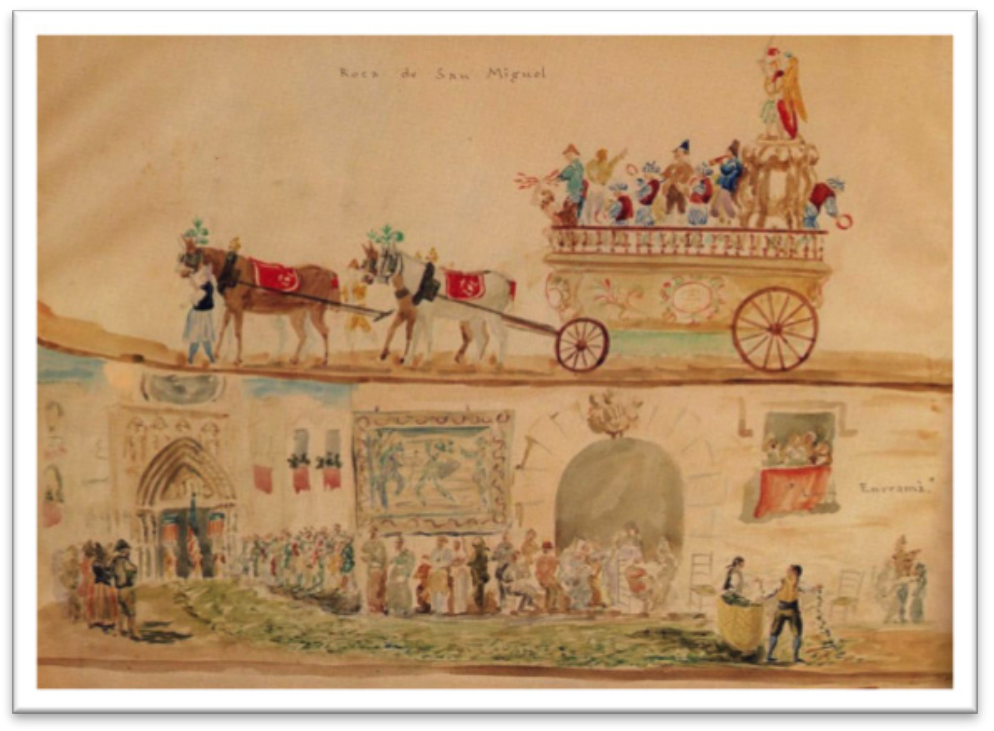

Fig. 7. Roca de sant Miquel a la processó del Corpus de València (Rotllo de 1824)

La roca de Tarragona de sant Miquel o l'infern havia adquirit una notable complexitat dramatúrgica durant el segle $\mathrm{XV}$, amb incorporació fins i tot de sorollosa pirotècnia. I any rere any la representació es nodria de nous elements escenogràfics; en aquest cas, un cadafal amb rodes que faria d'infern, segons consta en el pagament al fuster. A més a més, en la relació de l'entrada, la darrera posició (abans del «ball de negres») pertany al gremi de ferrers i fusters: «[...] Apres de aquexos vingueren los farres e fustes feyen los Gentils e anaven VII personatges molt concertats $[\ldots] \gg$. I Bertran identifica aquest «gentils» amb 'gegants' (bàrbars pagans), com són definits en altres documents posteriors. En conclusió, aquests quatre entremesos tarragonins provenen del cicle del Corpus, però fan una simbiosi amb els de les processons religioses de la festivitat de Santa Tecla, patrona de la ciutat, i es fan servir per a una entrada particular, en aquest cas d'un clergue notable, un arquebisbe. El contingut dels entremesos forma part, no cal dir-ho, de la temàtica litúrgica de la lluita entre el Bé i el Mal.

No resulta difícil, doncs, pensar que a l'imaginari dels espectadors i lectors de la corona d'Aragó de l'època els teixidors i ferrers d'una desfilada urbana es podrien haver associat als d'altres desfilades on podien haver representat entremesos com els documentats a Tarragona, en 1514, hereus probables, com hem vist, d'altres medievals ${ }^{45}$.

\section{La forca enmig del pont i l'aporia de la decisió justa}

La lluita -dinàmica- entre el Bé i el Mal, entre sant Miquel i els Diables, l'anomenada «Diablera (Fig. 8), o contra els «gentils» o 'gegants', on hem deixat els teixidors i ferrers tarragonins, requereix un lloc-estàtic- per a desenvolupar el Judici: aquest lloc serà un pont. I un jutge

45. Es podrien també esmentar, finalment, els carros o roques italians, que Martorell podia haver vist a Nàpols, on les màscares simbolitzaven també principalment els diferents oficis i l'objectiu de la representació era descriure tant els gestos i hàbits de cada ofici com al.ludir i referir gràcies als dobles sentits al gran tema de la pràctica de l'amor. Entre les professions representades en aquell moment, eren inevitables les de teixidor, ferrer, pintor, netejador de xemeneies, etc. Els millors documents literaris al voltant d'aquestes roques van ser el dels Canti carnascialeschi fiorentini, ja de lèpoca de Lorenzo il Magnifico (Cacho Casal, 2003: 17-18). 
/ Jutge imparcial i just: serà el duc. Però, abans, cal determinar la rellevància i seriositat del litigi entre Bé i Mal, entre innocents i culpables.

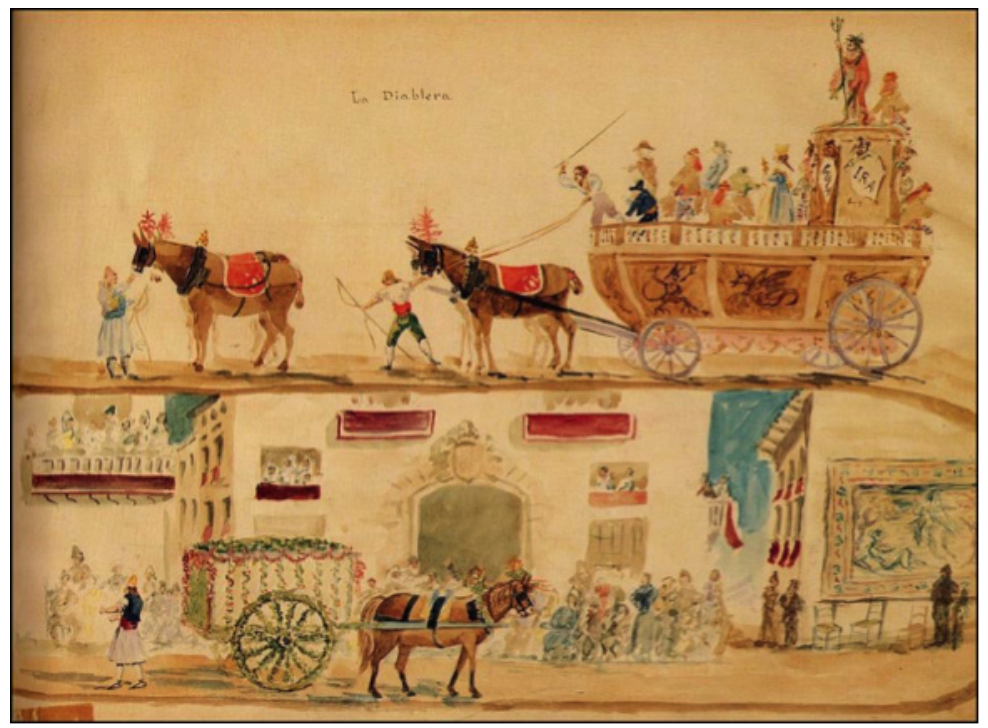

Fig. 8. Roca dels Diables -la «Diablera»- a la processó del Corpus de València (Rotllo de 1824)

I a l'episodi del Tirant, la discussió entre oficis sobre la seua preferència en la processó és estúpida, no té sentit com a discussió seriosa; ergo, no s'hauria d'haver plantejat mai. I tanmateix es planteja. Els jutges, doncs, no tenien res a fer en la decisió sobre un assumpte que era una simple tautologia, i no una causa civil ni penal. Els jutges no l'haurien d'haver pres en consideració, però no només l'accepten, sinó que són ells els qui alcen la causa, la fan casus belli i propicien la revolta dels oficis. Els jutges no haurien d'haver-hi participat mai. I, tanmateix, ho han fet. Aleshores, ara que la discussió absurda s'ha enredat més i més per culpa de la intervenció dels jutges, com un enigma sense solució o com el fil d'un cabdell, caldrà que algú en desenrede el nu endimoniadament embolicat. Potser com acabem de veure a sant Miquel, amb l'espasa, entre els dimonis.

Naturalment, tot és literatura i tot és ficció. Hem vist l'inici de la resposta del duc a la revolta. Enmig de la multitud («la pressa»), el duc, com un capità enmig de la batalla, trau tres juristes fora de la ciutat. Els juristes no s'imaginen el que els espera:

Lo duch se mès enmig de la pressa de tota la gent e pres sis juristes, tres de cascuna part, e tragué.ls fora de la ciutat. Ells se pensaren que lo duch los volia per demanar quala part tenia millor justícia.

A continuació, tot ocorre molt de pressa. L'acció del duc és inesperada i expeditiva: «Lo duch descavalcà enmig del pont e, tan prestament com pogué, féu posar dues forques ben altes e féu penjar tres juristes en cascuna».

La bestiesa de l'acció ( «féu penjar tres juristes en cascuna») no té justificació des del punt de vista històric, tot i que sí que ho tindria des del punt de vista de l'èpica, de la narrativa de ficció o de la religiosa (recordem sant Miquel). Tanmateix, no ens pot fer oblidar els elements circumstancials: un pont, dues forques enmig del pont... Per què el pont i les forques justament enmig del pont? Donat que tot és literatura, aquests elements, com el clau en la paret de Txékhov, han 
de tenir la seua funció. Les forques en tenen. Però, per què el pont? Per tancar el camí al poble revoltat? Ben bé podia haver sigut un camí o una muntanya...

Canviem per un moment de referent. Passem de nou a Don Quijote, una obra que sempre, com Tirant, és una mina de sorpreses. Semblant paisatge -el riu, el pont, la forca i els quatre jutgesens presenta un capítol molt interessant, amb un dilema, «La paradoxa del pont», que se li presenta a Sancho Panza quan es troba de governador a l'«ínsula» Barataria:

\begin{abstract}
-Señor, un caudaloso río dividía dos términos de un mismo señorío, y esté vuestra merced atento, porque el caso es de importancia y algo dificultoso... Digo, pues, que sobre este río estaba una puente, y al cabo della una horca y una como casa de audiencia, en la cual de ordinario había cuatro jueces que juzgaban la ley que puso el dueño del río, de la puente y del señorío... (II, LI; Cervantes, 1998: 1045-1046) ${ }^{46}$.
\end{abstract}

Tenim, el mateix que en Tirant, «un río», «una puente» i «una casa de audiència» amb «cuatro jueces». La llei que imposa l'amo del riu és, en aquest cas, una llei absurda, a la qual, tanmateix, s'han de sotmetre els treballadors o viatgers cada vegada que volen creuar-lo. Haurà de venir un petit heroi, un noi llest, per tal de trencar aquesta norma estúpida:

... la ley que puso el dueño del río, de la puente y del señorío, que era en esta forma: «Si alguno pasare por esta puente de una parte a otra, ha de jurar primero adónde y a qué va; y si jurare verdad, déjenle pasar, y si dijere mentira, muera por ello ahorcado en la horca que allí se muestra, sin remisión alguna». Sabida esta ley y la rigurosa condición della, pasaban muchos, y luego en lo que juraban se echaba de ver que decían verdad y los jueces los dejaban pasar libremente (1998: 1046).

El pont, la forca i els jutges són instruments d'amenaça i repressió absurdes. No estem davant d'un impost habitual de duana o de port, sinó que es tracta d'un joc arbitrari i tirànic, fet per a espaventar; no en trau profit ningú i tanmateix funciona mecànicament, com un rellotge. La pregunta és tautològica: «ha de jurar primero adónde y a qué va». Si es jura, es diu la veritat. Aleshores, els jutges no feien res, i havien de deixar passar a tots: «pasaban muchos, y luego en lo que juraban se echaba de ver que decían verdad y los jueces los dejaban pasar libremente». El joc no feia més que justificar l'actuació dels jutges, una actuació totalment innecessària. Però així funcionava tot... fins que un individu llest arriba i trenca les regles: «Sucedió, pues, que tomando juramento a un hombre juró y dijo que para el juramento que hacía, que iba a morir en aquella horca que allí estaba, y no a otra cosa» (1998: 1046).

El que fa aquest individu que es rebel.la al costum, quan es troba enfront d'aquest ritu de pas i aquesta duana irrisòria, és la formulació d'una simple paradoxa sense solució: dir que jurava que anava a morir en aquella forca. Aquest jurament posa en evidència el propietari del lloc (el riu), els jutges i posa en evidència, sobretot, el sentit de la mateixa llei:

Repararon los jueces en el juramento y dijeron: «Si a este hombre le dejamos pasar libremente, mintió en su juramento, y conforme a la ley debe morir; y si le ahorcamos, él

46. Strosetzki (2019) ha estudiat recentment, des d'una nova perspectiva, les sàtires judicials de Sancho i don Quijote, com aquesta. L'episodi de «La paradoja del Puente» del Quijote té un molt curiós precedent al cant XI de Las lágrimas de Angélica (1586) de Luis Barahona de Soto, poema cavalleresc que Cervantes va encomiar dins el seu escrutini del Quijote, I, VI. 
juró que iba a morir en aquella horca, y, habiendo jurado verdad, por la misma ley debe ser libre» (1998: 1046).

La paradoxa o aporia l'hem sentida a vegades en rondalles d'enginy: es crea un atzucac quan el camí no té eixida, quan un problema no té solució i dona lloc a conclusions absurdes. Es pot relacionar amb les apories o paradoxes clàssiques, com ara la d'Epimènides de Creta: «Jo dic que tots els cretencs són uns mentiders. Jo sóc cretenc. Aleshores, jo sóc mentider». O amb les de Zenó d'Elea, com ara la d'Aquil.les i la tortuga ${ }^{47}$.

No té importància en aquests moments detenir-nos en la resposta que dona Sancho Panza ${ }^{48}$. No pot ser correcta, ni lògica, perquè és una paradoxa sense solució, com la famosa paradoxa del barber, que exemplifica la paradoxa matemàtica sobre la teoria dels conjunts de Bertrand Russell ${ }^{49}$. El conte que se li planteja a Sancho deixa en ridícul -el mateix que en Tirant-el paper de la justícia en atendre normes irrisòries com les de la discussió dels oficis o el jurament del pont. $\mathrm{Al}$ conte de Cervantes els jutges tenen la forca com a instrument coercitiu i, tanmateix, aquesta mateixa eina se'ls gira en contra en l'episodi de Tirant: el condemnador condemnat.

D’altra banda, el pont on es troba la forca és un element previ de constricció i de revelació de la veritat. El pont, en un tipus de rondalla molt popular, obliga a passar d'un en un, en procés interminable, com en ATU 2300, Endless Tales, una rondalla -la desfilada inacabable d'ovelletes- que també fa servir Sancho Panza en un altre moment de Don Quijote ${ }^{50}$. Hi ha un tipus de rondalla, ATU 1920J, Bridge Reduces a Lie, dins el grup de rondalles sobre mentides grosses (ATU, 1920), en el qual un mentider arriba a un pont on diuen que s'enfonsa la persona que menteix. Aleshores, el mentider, per tal de poder passar, redueix la mida de la seua mentida. La «pressa» o multitud de Tirant («Ajustaren-se en cascuna part passats X mília hòmens») es redueix, quan arriben al pont, a «sis juristes, tres de cascuna part». Enmig del pont ja no valen les mentides exagerades de teixidors, ferrers i juristes: cal desprendre-se'n quan arriba el moment de la veritat.

Al remat, el pont estret obliga a confessar, com a l'episodi de Don Quijote, i revela que tot el que s'ha plantejat com a querella real no és sinó un joc de mentides i mentiders. El dilema, «La paradoxa del pont», que se li presenta a Sancho Panza ens ajuda a entendre que tampoc a l'episodi de Tirant no estem davant d'una lluita real entre qui té raó i qui no té raó, sinó entre qui formula una mentida més grossa (que es vol fer passar per veritat) ${ }^{51}$.

47. Dueñas Ruiz (2009) estudia l'episodi de Don Quijote acuradament, però des d'un punt de vista estrictament jurídic, i el compara també amb una altra paradoxa atribuida a Zenó, la de la fletxa i el vol.

48. La primera solució que proposa Sancho està al mateix nivell i és tan absurda i enginyosa com el problema plantejat; per tant, no s'hi val: «que deste hombre aquella parte que juró verdad la dejen pasar, y la que dijo mentira la ahorquen». I la segona i definitiva no serà lògica, sinó ètica, però sí que és vàlida: el perdó o absolució sense justícia, per bondat o caritat: «...que le dejen pasar libremente, pues siempre es alabado más el hacer bien que mal» (1998: 1047).

49. López Arnal (2006), com a matemàtic i filòsof, planteja lúcidament la relació del conte de Sancho Panza amb la paradoxa de Russell que, resumida, diu: «L'únic barber de la ciutat diu que afaitarà a tots aquells que no s’afaitin a si mateixos. Pregunta: qui afaitarà al barber? Si no s’afaita a si mateix serà una de les persones de la ciutat que no s’afaiten a si mateixes, amb la qual cosa hauria de afaitar-se, sent per tant una de les persones que s’afaiten a si mateixes, no havent per tant afaitar-se».

50. Don Quijote, I, XX (Cervantes fa servir cabres, en lloc d'ovelles). Cf. ATU, 2300, Contes inacabables (Oriol-Pujol, 2003: 369), com els de les deu mil ovelles. Els animals (o persones) travessen un pont que sols permet el pas d'un en un, en fila. Fins que no acaben de creuar-lo, no s'acaba el conte.

51. Als concursos, conteses o fights de mentiders allò més important és conèixer qui diu la barbaritat més gran. L'enfrontament o contesa entre els dos peresosos del Libro de buen amor, que han de guanyar-se el favors d'una dama, es descobreix com a concurs per 
Qui és més peresós? Qui és més mentider? Com veurem més endavant, a les bones rondalles de mentiders, com ara 1534D* (Sham Dumb Man Wins Suit), l'acusat atabala el jutge i decanta la sentència a favor seu. Al Tirant, els acusats no atabalen el jutge. El duc de Lencastre resol el litigi manu militari i trenca el miratge o el nus -la rondalla- de la grossa mentida (qui en diu de més estúpides, teixidors o ferrers?) d'una espasada, sense cap mirament, tal com Alexandre el Gran va trencar el nus gordià i va confirmar així la seua carrera de triomfs.

\section{Judes penjat: els juristes avars, penjats cap avall}

Els juristes són condemnats a ser penjats cap avall i esquarterats. L'exagerada condemna que sofreixen coincideix amb el càstig màxim que es podria donar, i només excepcionalment i en alguns llocs de l'occident medieval, als traïdors d'alta traïció. Un càstig, però, que, sense deixar de ser versemblant, concentra tota mena de representacions simbòliques i hiperbòliques de l'imaginari medieval.

Evidentment, la forca, com a càstig radical i letal d'aplicació de justícia, era un exemple de dissuasió. Dissuasió paorosa, però justa, com diu el Canceller Pero López de Ayala, al seu Rimado de Palacio, «bien pareçe en la forca çierto el malfechor, / ca es para los malos espanto e pavor, / señal es de justícia e de buen regidor» (estr. 614). Això no vol dir que la classe de condemna a mort, enforcats, que reben uns ciutadans tan respectats com els juristes al Tirant, agreujada per la manca de sepultura, no siga realment un oprobi insuportable. A més a més, crida l’atenció, com a especificació més que significativa, que siguen condemnats a morir penjats «cap avall per fer-los molta honor». Recordem-ho:

Lo duch [...] féu posar dues forques ben altes e féu penjar tres juristes en cascuna, cap avall per fer-los molta honor; e no.s partí de allí fins que agueren tramés les miserables ànimes en infern.

A aquesta mort seguirà la ratificació i incrementació de la pena per part del nebot del duc, el rei: «Per què yo man que stiguen açí en la manera que stan fins a demà, e aprés sien-ne fets quartés e posen-los per los camins $\gg^{52}$. És a dir, el rei mana que, a més, al sendemà els cossos dels juristes morts a les forques siguen esquarterats («fets quartés»), fets a trossos, deixant-los després dispersos qui sap per on. Martorell va poder sentir parlar del cruel càstig durant el seu viatge a Anglaterra, o fins i tot veure'l en algun moment posat en pràctica. No a València ni a Nàpols. Perquè l'execució del tipus «penjat, arrastrat i esquarterat», que sembla pròpia del martirologi cristià -com en el cas de sant Hipòlit- o dels textos de ficció èpica -com en la mort del traïdor Ganeló a la tradició carolíngia- hi va ser implantada històricament a les Illes britàniques des de 1351 per castigar els qui eren trobats culpables d'alta traïciós ${ }^{53}$.

a saber qui diu la mentida més grossa sobre el seu vici, en aquest cas la peresa (Pedrosa i Traoré, 2014). Al remat, la dama descobreix i trenca el miratge del concurs quan rebutja tots dos (ATU, 1950).

52. Com explica Hauf per a «esquarterats»: «Cruel forma de justícia medieval aplicada als pitjors malfactors, que consistia en fer a trossos els cossos dels condemnats, deixant-los després exposats en llocs públics, per a escarment popular». És curiós el contrast entre aquest «esquarterats» i els nobles de «quatre cortés» (= 'quarters'), és a dir, 'nobles per tots els linatges', dels que ha parlat abans, al mateix capítol 41. Cf:: «se feren cavallers passats LX gentils hòmens de nom e d’armes e de quatre quarters» (Tirant, c. 49).

53. El càstig va ser registrat per primera vegada durant el regnat del rei Enric III (1216-1272) i del seu successor, Eduardo I (12721307). Els convictes eren lligats i arrossegats per un cavall fins al lloc de l'execució; un cop allà, eren penjats (gairebé fins al punt 
No tenim dubte de l'existència històrica de casos especialment cruels de condemnats a mort penjats pels peus, cap cap avall -tot i que no esquarterats-, a la nostra Península, per bé que també foren força rars. Bazán ha estudiat la seua excepcionalitat en la Corona de Castella:

La tradicional soga al cuello de la horca de tres palos, en la que la muerte se produce por fractura ósea o asfixia, es sustituida por la posición invertida del cuerpo del reo; es decir, los pies en alto y la cabeza abajo. De esta forma el reo es colgado por los pies y la muerte resulta mucho más cruel, debido al dolor que causa y a la lentitud con la que se produce, pues tarda en producirse entre dos y tres días (Bazán, 2007: 319).

El Fuero Real de Castella preveia, en concret, aquest sistema d'execució per al cas dels sodomites, que primer eren castrats i després penjats dels peus, i d'aquesta manera romanien perpètuament en el record dels qui podien contemplar-ne les despulles ${ }^{54}$. Bazán constata si més no dos casos de condemna seguint aquesta llei: un d'acusació d'homosexualitat masculina, en 1491, i un altre d'homosexualitat femenina, en 1503. En aquesta segona, com que no es van poder provar els fets, la forca va ser substituïda per desterrament perpetu de la vila (San Sebastià, al País Basc), però amb l'avís que si la dona tornava:

la dexasen estar ende publicamente fasta que muryese asy colgada pies arriba naturalmente fasta tanto que ovyese mandamiento de juez conpetente non la abaxasen e dexasen estar en exemplo, terror e castygo de los que lo ovyesen.

«...la dexasen estar ende publicamente fasta que muryese asy colgada pies arriba». Recordem en Tirant: «féu penjar [...] cap avall [...] fins que agueren tramés les miserables ànimes en infern». I com veurem més endavant en un exemple oriental, però relatat per escrivans castellans, l'Embajada a Tamorlán, el Gran Tamerlà, després de sotmetre a turment el seu privat, «mandólo enforcar por las piernas fasta que murió» (cf. $\$ 9$ ).

A la Corona d'Aragó, en canvi, aquesta modalitat d'execució capital no s'exercia sobre sodomites (o no en coneguem casos), sinó sobre jueus i musulmans, és a dir, sobre infidels (Pons, 1960: 449-453). Aquest càstig adreçat als jueus sembla que era comú en altres regnes europeus, com a mínim des del segle XIII en Alemanya (Fig. 4).

Tant en un cas (condemna a sodomites) com en l'altre (a jueus i musulmans), i tot i l'èmfasi evidentment irònic de Martorell («cap avall per fer-los molta honor»), aquesta damnatio ens recorda la dels personatges morts dels quals no es pot parlar, és a dir, infames, «cadàvers sense els honors del sepulcre», que apareixen quan a l'Antic Testament es parla de pecadors enemics de Déu, oposats als seus projectes ${ }^{55}$.

de morir), eviscerats (trets els budells), cremats, decapitats i esquarterats; de vegades, prèviament arrossegats ( «hanged, drawn and quartered»). Sovint, les seues restes eren exhibides en llocs importants, com ara el pont de Londres. Les dones condemnades per alta traïció eren, en canvi, cremades a la foguera, per qüestió de decència.

54. Si es trobava que: «un omne cubdiciaua a otro por peccar con él contra natura, ma[n]damos que qualesquier que sean que tal peccado fagan, que luego que fuere sabido, que sean amos a dos castrados ante todo el pueblo, e después a terçer día que sean colgados por las piernas fasta que mueran e nunqua dent sean tollidos» (Fuero Real, lib. IV, tít. 9, ley 2; apud. Bazán, 2007: 319).

55. Alguns d’aquest atacs es llegeixen, por exemple, al Salm 69, 23-29; o al Salm 109, 6-19: «Que porti un injust la seva causa, que tingui un fiscal per defensor. 7 Que surti condemnat en el judici i la pregària encara li augmenti la culpa. 8 Que duri poc la seva vida i un altre ocupi el seu càrrec. [...]» (Salm 109, 6-8). 
Des de l'Antiguitat la sepultura digna ha sigut una necessitat imperiosa. I la pitjor condemna a un home és la mort «sense els honors del sepulcre» (Saviesa, 4,19), però a més maleït i burlat, i ser motiu de riota, abans i després de mort ${ }^{56}$. Al Tirant, els cadàvers, després de penjats, són esquarterats, el que és encara més greu que ser maleits i burlats. Però, com hem dit abans, a la Corona d'Aragó la condemna a ser penjats boca cap avall afecta a jueus i musulmans. I la pitjor mostra de la història dels jueus de tot el cristianisme havia sigut el cas de Judes Iscariot. Judes va ser considerat la quintaessència del mal. I, en efecte, es va convertir en un cadàver infame, inic, objecte d'oprobi etern, que no podia ser dignament soterrat. En algunes versions, basades en textos evangèlics, Judes se suïcida tirant-se des d'una certa alçària cap avall ${ }^{57}$.

Em sembla evident una associació o identificació, al Tirant, entre els jurats penjats i el Judes impiadós i avar. Judes va ser considerat a l'Edat Mitjana, no només l'Avar, sinó també el Traïdor per antonomàsia. I el traïdor... «en gran pecat deu rebre pena gran», com diu Ausiàs March. Perquè la traïció de Judes i el seu càstig van arribar fins i tot a la millor poesia amorosa de l'època. March, cunyat de Martorell, associa el sofriment amorós amb el menyspreu al propi jo líric, que es condemna per traïció a la pitjor mort. Una mort que, com la de Judes («aquell / qui volc trair, besant lo Fill de Déu»), no ha de ser una mort qualsevol: «No dec morir solament ab coltell: / mon cos mig mort deu ser vianda als cans, / mon cor partir entre corbs e milans; / mon espirit tinga lo lloc d’aquell / qui volc trair, besant lo Fill de Déu: / aquest és lloc a ell just e degut; / puis ha traï a si, Déu no l'ajut. / En gran pecat deu rebre pena gran» (XCIX, XI). (Fig. 9)

56. Al llibre de Saviesa, 4, 16-19, els cadàvers sense sepulcre són «motiu etern de riota»: «[16] El just que mor és una condemna per als impius que sobreviuen; un jove que arriba aviat a la maduresa condemna la llarga vellesa dels injustos. [17] La gent veu la fi del savi, però no comprèn què volia d'ell el Senyor, no comprèn per què se l'ha endut en un lloc segur. [18] Ho veuen i sén burlen, però qui es riu d’ells és el Senyor. [19] D’aquí a no gaire, aquests burletes seran un cadàver sense els honors del sepulcre, motiu etern de riota al país dels morts. Déu els precipitarà de cap a terra, sense que puguin dir res; els sacsejarà des del fonament i quedaran devastats per sempre més. Es trobaran amb el dolor. Mai més ningú no els recordarà».

57. Sant Pere, als Fets dels Apòstols, 1, 16-19: [16] -Germans, calia que es complís allò que l'Esperit Sant havia anunciat en l'Escriptura per boca de David referent a Judes, l'home que va guiar els qui agafaren Jesús. [17] Era un del nostre grup i havia estat designat per a participar d'aquest mateix ministeri. [18] Doncs bé, aquest home es va comprar un camp amb la paga del seu crim, es va tirar de dalt a baix, se li va obrir el cos pel mig i s'escamparen les seues entranyes. [19] Tots els habitants de Jerusalem van conèixer el fet i van anomenar aquell camp, en la seua llengua, Hacèldama, que vol dir 'camp de sang'». No estic segur que aquesta mort infame no siga la de Pármeno i Sempronio a La Celestina. Tots dos, pecadors i assassins per cobdícia, avars, moren tirant-se des d’una alçària; el cos o el cervell s'escampa d'igual manera. He tractat el tema més extensament en un article dedicat a la presència i absència de Judes a $L a$ Celestina (Beltran, 2020). 


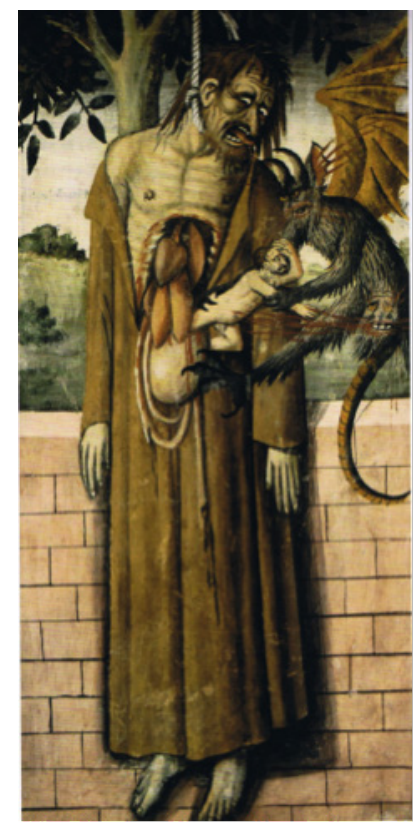

Fig. 9: Giovanni Canavesio, Sü̈cidi de Judes

(Notre-Dame des Fontaines, La Brigue, c. 1491)

A més a més, la bossa característica de Judes passarà a la iconografia popular com a atribut de l'avar. I així, com a avar, recorda Judes el Tarot més antic, del segle XV, en una carta que es presta encara a la interpretació: un Judes penjat cap avall, que ni en aquesta difícil posició amolla les dues bosses de diners, una en cada mà (Fig. 3).

Dante Alighieri presenta Judes, a la regió més profunda de l'Inferno, XXXIV, Judeca, devorat per Llucifer, junt amb Brut i Casi ${ }^{58}$. Tots tres devorats per Llucifer tenen en comú ser pecadors contra el Govern (allò que serà després l'Estat): traïdors d'alta traïció. Abans, al cant XV, v. 110, Dante ja havia presentat un famós jurista de Bolonya, Francesco d'Accorso, patint les flames entre altres sodomites. Brisset (2000) i Toldrà (2018) han estudiat molt bé, a més a més, com una llegenda d'un Judes que és recordat amb la mateixa trajectòria biogràfica d'Èdip -mata a son pare i es casa amb sa mare-, versió que replega Jacopo Varezze a la Llegenda aurea, es fa molt popular i arriba al teatre medieval, on les «consuetes» l'arrepleguen perfectament fins al segle XVI. Kovács (2008), efectivament, ha estudiat la profusa trajectòria de la mort de Judes -antítesi de la mort de Jesucrist- en el teatre medieval. Judes, a més de traïdor, s'havia convertit, doncs, en un terrible assassí que havia comès incest. Un Judes incestuós era igual o pitjor que els sodomites que hem vist que eren castigats a ser penjats dels peus al regne de Castella (Fig. 9).

Els juristes s'identifiquen al Tirant, em sembla, amb jueus avars i traïdors. El pecat dels juristes és elevat a la categoria de delicte de cobdícia, però també de delicte d'alta traïció, prop de la traïció a Déu de Judes ${ }^{59}$. Una absoluta exageració, des de qualsevol punt de vista social, com tantes altres de la novel.la. Evidentment, el que Martorell ens presenta és una escena de caricatura 
grotesca de la realitat, però caricatura ja present en moltes representacions figuratives amb Judes com a protagonista.

\section{El Judici final i el braç executor: Neró i Herodes}

La dels juristes potser no seria l'única caricatura de l'episodi. El duc no n'ix estalvi. En la lluita entre Ardiment i Saviesa que hem vist reproduïda abans, dins el debat entre la Princesa i l'Emperadriu, el duc representaria l'Ardiment... sense Saviesa. És a dir, representaria una solució en fals, entre imprudent i dictatorial.

\subsection{El braç executor: el duc de Lencastre}

Pot semblar, en una primera lectura superficial del text de Tirant, que l'actuació del duc de Lencastre ha sigut bona per a la salut del regne: profilàctica, ràpida i quirúrgica davant la perillosa actuació dels juristes. No seria tampoc, des del punt de vista històric, d'una total inversemblança. Coneixem casos d'actuació senyorial prepotent, en la corona d'Aragó, manant enforcar vassalls per causes menors contravenint la jurisdicció reial, fins al regnat de Felip III (Bermejo, 2005: 342). Però resulta evident que no ens podem prendre seriosament el seu comportament, ni en podem extraure una lliçó modèlica. El duc ha resolt amb tirànica supèrbia, taxativament, tot d'una, dos problemes relacionats amb dos classes socials diferents, menestrals i juristes; ha fulminat amb la força inapel-lable de les armes (menyspreant la llei) una desproporcionada baralla al voltant d'una dissensió insignificant (que s'havia exagerat i multiplicat estúpidament en acudir a una justícia ineficaç quan no hi calia); i, de passada, se suposa que ha fixat un model per a futurs governants que s'hagueren de trobar amb problemes semblants d'inoperància. La lliçó diria que cal eliminar de bestreta els causants de l'extensió de les malalties burocràtiques (les paperasses inacabables), que no són altres que els juristes que fan que aquestes es multipliquen i eternitzen.

El rei d'Anglaterra aplaudeix la resolució, però ni el rei és fiable (de fet, és molt feble, i per això ha delegat prèviament el poder en el duc); ni el duc és el duc de Lancàster històric; ni el contingut palesament desgavellat de l'episodi és el més propici per entendre'l com una història «moralitzant» (com a molt satírica); i, finalment, el context festiu -la parcialment carnavalesca entrada reial del Tirant i el sentit d'humor festiu d'altres episodis de la novel-la- tampoc no és el més idoni. Altra cosa hagués sigut si el relat hagués estat en boca de Varoic, o amb la seua aquiescència, que ací no tenim.

Davant el personatge, hem de preguntar-nos si tenia alguna correspondència històrica aquest duc de Lencastre. Perquè «Enric» és el rei d'Anglaterra en la novel.la, un nom ben anglés i històric, el d'Enric VI (1421-1471), el rei que va conèixer bé Martorell en la realitat històrica, o el del seu pare, Enric V (1387-1422) ${ }^{60}$. Tanmateix, el duc de Lancaster (sempre «Lencastre» al text) fa un paper de tutor més aviat irregular i indefinit al text, i hem de de posar en dubte que s'hi mantinga un mateix reflex unívoc amb un personatge històric correlatiu, començant perquè aquest ducat pertanyia al rei mateix, és a dir, el títol del ducat de Lancaster estava unit a la Corona anglesa des de l'any 1413 (data de l'ascens al tron d'Enric V). 
El duc, que es presenta fins a tres vegades al Tirant com a oncle del rei ${ }^{61}$, apareix en diverses ocasions: al cap. 14, a la història de Guillem de Varoic, es nomenat, juntament amb el comte de Salisbury, representant del rei anglés per rebre els ambaixadors del rei de Canàries que acaba d'envair l'illa; al capítol següent, el 15, el duc és proposat pel comte-ermità, tenint en compte la joventut i feblesa del rei, com a contrincant per a la batalla amb el rei de Canàries, designació que desperta les protestes dels ducs de Gloucester, de Bedford i d'Exeter. A continuació, ja en la secció de les bodes, el duc figura, com hem vist, al comandament de l'avantguarda del seguici reial, «tot armat en blanch, ab XV mília combatents», i tot seguit com a executor dels juristes (cap. 41). Després, com el cavaller que «en presència de tots donà l'orde de cavalleria al rey» (cap. 43). Finalment, el duc de Lencastre és mencionat, en el capítol 85, entre els vint-i-cinc cavallers elets, fundadors de l'orde de la Garrotera.

A l'hora de transposar aquestes dades la realitat històrica, Sasor (2008) ha vist coincidències molt plausibles amb el personatge del duc i Humphrey Plantagenet, duc de Gloucester (13911447), cinquè fill d'Enric IV Lancaster, i germà, per tant, d'Enric V (sota les ordres del qual va combatre en Agincourt, 1415). Noble humanista i amb fama de generós, Humphrey pertanyia al llinatge reial de Lancaster, però no podia haver sigut nomenat duc de Lancaster perquè, com hem dit abans, el ducat era propietat del rei des de 1413. Però Humphrey sí que va ser oncle del rei Enric VI, i per aquest parentesc va ser regent durant la minoria del rei, malgrat l'oposició del seu germà més gran, Joan de Lancaster, duc de Bedford, i del bisbe Enric de Beaufort. Creu Sasor que aquest doble motiu (regència i parentesc) podria haver sigut raó suficient per a rebre el títol de duc de Lancaster per part de Joanot Martorell, qui podia fins i tot haver-lo conegut personalment a la seua estada a Londres. És cert que al cap. 15, quan l'ermità proposa que el duc de Lencastre fos alçat per rei, per tal de combatre -rei contra rei- contra el rei de la Gran Canària, tres ducs, com hem vist abans, es rebel.len: «lo duch de Cloceste, lo duch de Bètafort, e lo duch de Atrètria», és a dir, els ducs de Gloucester, Bedford i Exeter (Àtçetera) ${ }^{62}$. Tanmateix, el paper de Humphrey, duc de Gloucester, sobretot quan va morir el seu germà, el duc de Bedford, en 1435, va ser fonamental en relació amb la corona. El seu nebot encara tenia dotze anys i ell va ser molt influent inicialment, encara que els seus constants fracassos bèl.lics en la guerra amb França li van fer perdre autoritat, fins al punt de ser empresonat i morir malalt en presó.

No es pot fixar, doncs, una figura referencial definitiva i exclusiva per al duc de Lancaster, tot $\mathrm{i}$ que la relació entre oncle responsable i rei jove i inexpert sí que podria reflectir d'alguna manera la relació entre Gloucester (no Lancaster) i un jove Enric VI. Fet i fet, el duc de Lencastre de Tirant es comporta com un jutge suprem perfecte, però també com un tirà, com un dictador, tot actuant per damunt de la llei. No un «tirà» en el sentit (polític) grec o romà, sinó en el sentit modern ${ }^{63}$.

61. «...lo duch de Lencastre, qui és honcle de mon senyor lo rey» (cap. 15); «com lo rey sabé tal nova, prestament anà hon era lo duch e dix-li semblants paraules: -Mon oncle, en lo món no.m podíeu fer major plaer...» (cap.41); «...i vench lo duch de Lencastre, honcle del rey» (cap. 43).

62. Si seguim Sasor (2008), doncs, les contradiccions a la novellla respecte als títols nobiliaris anglesos són tan paleses que fan pensar que Martorell no en disposava d'informació completa. Lequivocació entre «lo duch de Lencastre» i Humphrey de Gloucester podria fer-se extensible a Ricard Plantagenet, duc de York, besnét del rei Eduard III i cosí de Enric VI, qui ja va ser assenyalat per Entwistle (1927) como el possible duc de Lencastre.

63. En el mateix sentit en què -fonèticament- serà vista l'associació «Tirant»- «tirà» per un bon coneixedor de la política del segle següent com Antonio de Guevara. En una de les seues Epistolas familiares, el bisbe de Mondoñedo inclou un «Tirán», que sens dubte es «Tirant», enmig d’una curta nòmina d'herois històrics castellans. Vegeu Beltran (2019: 104-108). Tirant és d’alguna manera un «tirà», com es juga en algun moment de la novellla. Com diu el mariner turc del cap. 163: «... lo seu nom és lleig e vil, per ço com Tirant vol dir usurpador de béns o, més propi parlar, lladre». El mateix Tirant qualifica al rei Escariano així: «com tu sies tan magnànim 
Com deia Eiximenis, en la cita abans comentada, «los tirans en Itàlia així mateix fan espatxadament les causes determinar».

\subsection{Neró i Herodes}

En aquest sentit, i atenent al potencial d'imaginari que es concentra a l'episodi, voldria fixar la mira en dos dels més depravats tirans de l'Antiguitat, que sens dubte van ser dos romans: Neró i Herodes. L'actuació «tirànica» del duc ens els recorda, amb totes les cauteles i diferències, quan es presenta com una mena de Caront aparegut ex machina, per tal de decidir, com el president d'un tribunal de Justícia final, sobre les ànimes que se salven o condemnen. Neró representa per a la memòria occidental la crueltat del poder, i específicament per al cristià la crueltat per la repressió ignominiosa dels màrtirs. ${ }^{64} \mathrm{I}$ Herodes representa per a l'imaginari cristià la crueltat per la descreença en l'adveniment de Jesús (front als reis Mags) i, sobretot, la responsabilitat imperdonable de la matança dels sants innocents, la popular «Degolla» de les representacions teatrals i artístiques.

Si anem al primer personatge, observem que, en algunes imatges medievals, advocats i Neró rivalitzen per tindre un lloc a l'infern. En un exemple medieval tret d'una de les col.leccions més conegudes i traduïdes de l'Edat Mitjana, l'Alphabetum d'Arnau de Lieja, Neró es troba a l'infern amb els advocats. ${ }^{65}$ La versió catalana, replegada dins el Recull d'exemples e miracles..., diu així:

EXIMPLi E MIRACLE DE UN MAL ADVOCAT QUE VEÉ NERÓ, L'EMPARADOR, EN INFERN Advocati punintur in inferno. Ex quadam tragedia Senece.

Segons que recompte [Sèneca], un advocat, aprés que fon finat, anà als inferns e veé Neró emperador malbanyant-se en or bullent. E quant Neró veé entrar en infern aquell advocat, e molts altres advocats, dix-los: «Linatge vendible de hòmens, amichs meus, avocats, acostats-vos ençà a penar ab mi! $\gg^{66}$.

Aquest exemple es recordat per Yarza quan explica un dels fragments (tondo o cercle inferior esquerre) de la famosa Taula dels set pecats capital d'El Bosco. Al retaule, els cercles exteriors a la taula rodona estan dedicats a les darreres etapes de la humanitat: la mort, l'infern, la glòria i el judici final. Al tondo de l'infern es representa un paisatge d'ombres i focs, on nombrosos diables castiguen els condemnats i l'avarícia es mostra a través d'un advocat que es troba banyat en una caldera envoltat amb or, que recorda - per a Yarza- el text de l'exemple del Recull on Neró reclama que els jutges l'acompanyen perquè s'ho mereixen tant com ell (Gámez, 2017) (Fig. 10).

príncep deuries ésser just e no voler tenir nom de tirà» (c. 308). El treball més complet sobre les connotacions del nom de «Tirant» és el de Guia (2001).

64. A partir del segles III i IV, es va difondre la creença que Neró, a més dels assassinats a romans, va manar assassinar sant Pere i sant Pau. L’apòcrif del Fets de Pere o Actes de Pere parla de la crucifixió boca avall de sant Pere.

65. «Legitur autem in tragedia quadam Senece quod visum est cuidam quod videret Neronem apud inferos balneantem ministrosque circa eum aurum fervens infundere dicentemque cum videret chorum advocatorum ad se venientem : a Hue/ inquit, a venale genus hominum, advocati, amici mei accedite ut mecum in hoc vase balneetis, adlmc enim superest locus in eo quern vobis reservavi». 66. Recull, núm 37 (Ysern, 2004, I: 183). L’exemple és destacat per Rodríguez Barral (2007: 85-86), quan estudia el tema de la justícia del més enllà en la iconografia de la corona d’Aragó a la baixa Edat Mitjana. 


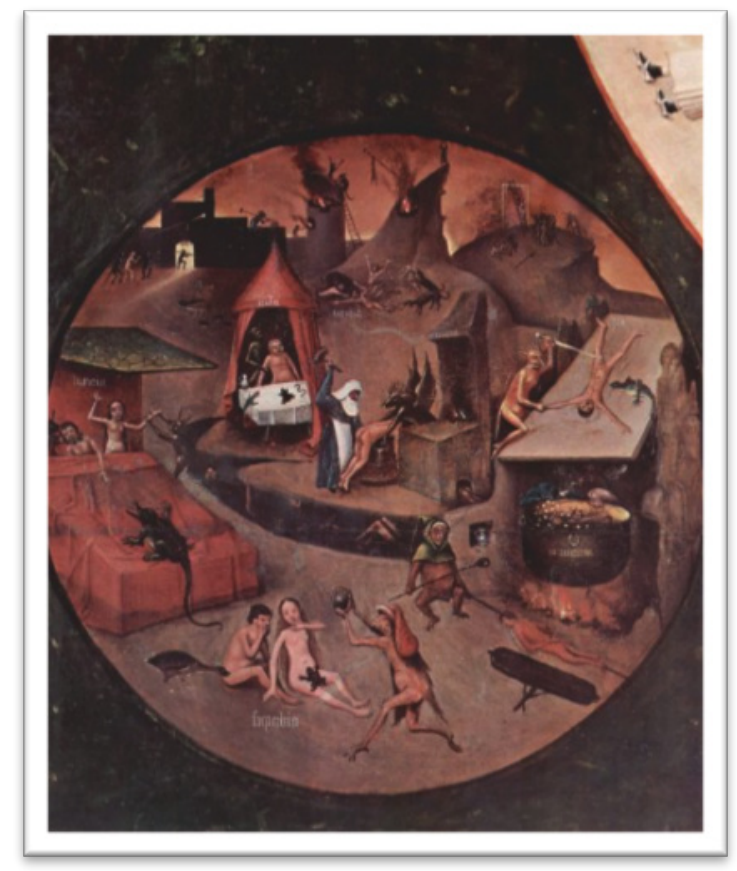

Fig. 10. El Bosco, Tondo de l'infern dins la Taula del set pecats capitals (Museu del Prado)

És possible que Martorell conegués aquest exemple a partir de la versió castellana, que ofereix el Libro de los ejemplos por A.B.C. de Clemente Sánchez, donat que Martorell fa servir un altre exemple d'aquest mateix Libro de los ejemplos en castellà -que no es troba dins la versió catalanaper a l'episodi del filòsof de Calàbria, dins l'estada de Tirant a Sicília ${ }^{67}$. La versió castellana de l'exemple del mal advocat és pràcticament idèntica a la catalana ${ }^{68}$.

El Recull d'exemples e miracles presenta altres quatre exemples amb Neró com a protagonista, sempre cruel (191, 192, 193 i 575). Però aquest és l'únic exemple que inclou els advocats, coincidint amb el motiu folklòric X316: Nero has reserved place in hell for lawyers ${ }^{69}$. En canvi, els advocats, que sempre apareixen com a «mal advocats», compten dins el Recull amb quatre exemples (núms. 33, 34, 35 i 37), sempre de to satíric i exagerat com aquest. La qual cosa reflecteix que l'església assumia com a propi i se n'aprofitava del menyspreu popular a l'ofici d'advocat.

Podem pensar, doncs, com déiem al principi d'aquest apartat, que el duc de Lencastre no n'ix estalvi, de l'episodi. El duc presenta qualitats caricaturitzades de «tirà» i probablement es condemnaria, com Neró, al mateix infern que els juristes que ell mateix condemna. En tot cas, cal

67. Vegeu Beltran (2006a: 202-218; 2006b), on resumisc les diferents opinions respecte a la font que donaven Martí de Riquer i Avalle-Arce.

68. La versió castellana duu per títol Advocati venale genus dicitur esse i l'exemple corresponent, el núm. 12, va precedit pels versos «Los abogados, según parece, / es gente que se vende e empesca». Diu així: «Onde léyese en unos cantares que fizo Sèneca que pareció a un ombre que vio al emperador Nero que se bañava en los infiernos e los servidores que estaven acerca dél que lançavan sobre él oro ferviente. E vio venir una compaña de abogados e díxoles: - $\mathrm{O}$ mis amigos, linaje de ombres que se venden, llegátvos acá e bañátvos aquí conmigo!» ([ed.] Gutiérrez Martínez, 2009-2010: 16). Baldissera (2000), al seu estudi sobre les fonts de Clemente Sánchez, confirma que la versió castellana és molt semblant a la catalana.

69. Localitzat per Neugaard (1993) dins la tradició medieval catalana. Vegeu també anècdotes sobre advocats, en ATU, 1980 (1860A, Lawyers in Hell; i d’altres) i sobre jutges (ATU, 1981). 
remarcar més que altra cosa el clima apocalíptic, relacionat amb les condemnes de l'infern, d'una figura tan coneguda com la de l'emperador romà.

L'imaginari al voltant de la figura d'Herodes seria d'un caire molt diferent (Fig. 11). Sempre he pensat que l'imaginari al voltant del personatge d'Herodes té molt de protagonisme als capítols que relaten l'affaire entre l'Emperadriu i Hipòlit, i que, com se sap, compten entre els més agosarats i divertits de tota la novel.la (caps. 248-264). Quan la donzella Eliseu sorprén a l'Emperadriu aixecant-se del llit a deshora, per anar al rendez-vous concertat amb Hipòlit al terrat, la dona inventa com a excusa que s'havia oblidat de resar una «devota oració» que deia cada nit. I quan la noia li pregunta ingènuament sobre el contingut de la pregària, l'Emperadriu contesta que es tracta d'una oració dels Tres Reis d'Orient, que havien visitat el rei Herodes de camí de Betlem, però que després d'adorar el nen Jesús van ser advertits en somni de no tornar a veure' $1^{70}$.

Per als Reis Mags va ser Herodes l'escull principal. Però per a l'Emperadriu, enmig del seu camí cap a l'amor d'Hipòlit, l'entrebanc serà la tafanera donzella Eliseu. Eliseu parla en determinat moment com Herodes, sobreactua com Herodes i arriba a ser tan cruel i ridícula com Herodes, almenys com l'Herodes teatral i covard que va anar forjant a Europa bona part de la tradició popular, en gran manera a l'empara de les representacions al seu voltant de la litúrgia del cicle nadalenc ${ }^{71}$. I si Eliseu confon la seua veu amb la d'Herodes, Hipòlit es converteix en un nen innocent (fins a tres vegades s'esmenta que està xuclant la mamella de l'Emperadriu), com si fora una víctima de la popular Degolla dels Sants Innocents, representada per la inquisidora amenaça d'una Eliseu-Herodes, portaveu de la llei i la moral. Confirma aquesta associació un dels gestos desmesurats d'Hipòlit, que comentem a continuació.

\footnotetext{
70. «...en la nit, la primera stela que veuràs, agenolla’t en terra, e diràs tres paternostres e tres avemaries en reverència dels tres reys d’Orient, que.ls plàcia voler-te recaptar gràcia ab lo gloriós Déu Jesús e ab la sua sacratíssima Mare, que axí com ells foren guiats e guardats, anant vetlant, dormint e estant, de les mans del rey Herodes, que.ls plàcia voler-te recaptar gràcia que sies liberada de vergonya e infàmia, e que totes les tues coses sien prosperades e aumentades en tot bé. E sies certa que obtendràs tot lo que vulles. E no.m torbes de ma devoció» (cap. 260; Martorell, 2005: 974-975). Recorda Mateu, 2, 12-16.

71. En una Adoració dels Reis Mags mallorquina, que ha estudiat Hauf, Herodes parla amb la mateixa estridència exagerada que Eliseu: «Ai de mi, desgraciat! / Mon cor pateix Grans torments / des que n'he decretat / la mort de tants d'innocents! / Sa sang sens Dubte als cels / contra la meva crida venjança; / ja he perdut sa esperança; / tenc és dolors més cruels. / Sa corona em cau d'es cap... / es cetre em fuig de ses mans, / i de ràbia, en breus instants, / moriré desesperat...». Vegeu més extensament, per al tema, Beltran (2001).
} 


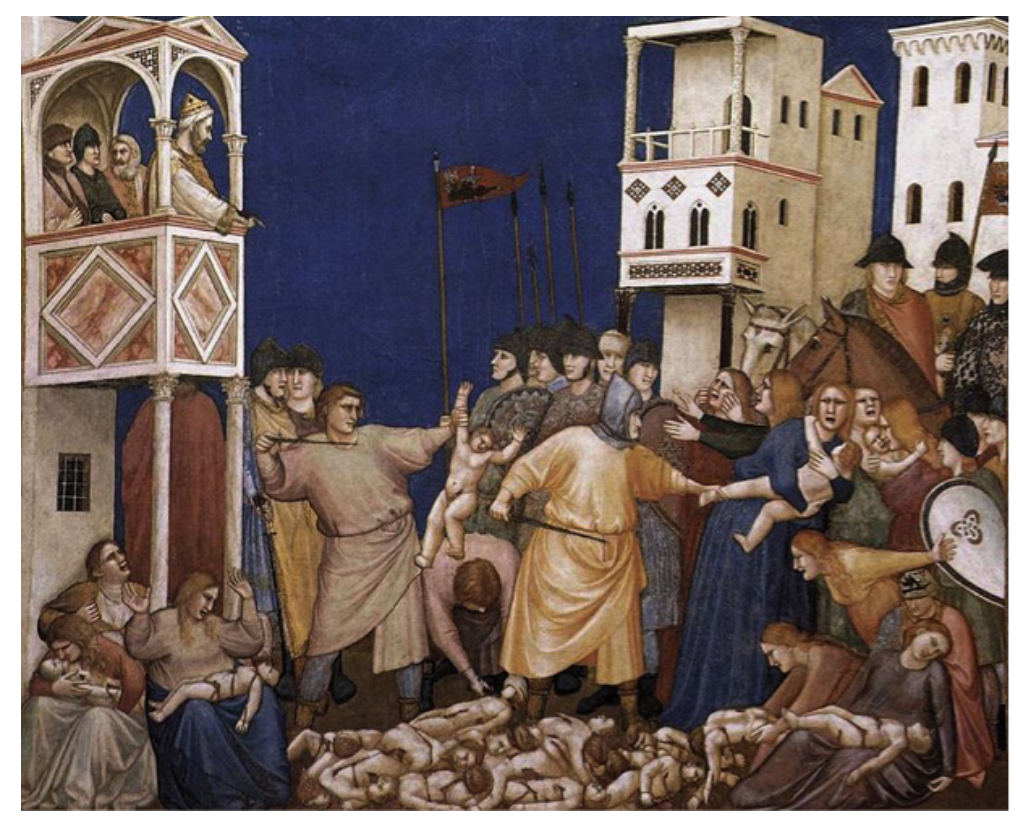

Fig. 11. Giotto, Massacre dels Innocents. Fresc de la Capella del Scrovegni, Pàdua (c. 1304-1306)

Pocs gestos més explícits d'acció teatral al drama medieval que l'intent de suïcidi d'Herodes (pecador, com Judes, de crim nefand), quan s'assabenta que els Reis Mags han tornat per un altre camí i se li han escapat. Al drama llatí de La matança dels Sants Innocents, recollit dins del conegut manuscrit de Fleury, «Herodes, molt alterat, agafarà l'espasa i fa com si s'anés a suïcidar» (traducció meua). El gest desorbitat provocava sens dubte la hilaritat entre els espectadors. De la mateixa manera, Hipòlit fa com si s'anés a suïcidar amb l'espasa, en ser descobert al llit de l'Emperadriu, i sentir els crits d'Eliseu i les expressions de por d'aquella, «pres-li gran pietat de si mateix, axí com aquell qui en semblants negocis jamés se era vist. $\mathrm{E}$ ab poca edat que tenia, féu companya a la emperadriu, servint-la de llàgrimes més que de consell ni remey» (cap. 262: Martorell, 2005: 981). No obstant això, canvia el plor per una sobtada decisió:

Emperò pregà a la donzella que li fes gràcia que li portàs la spasa qui en lo retret stava, e dix, cobrant ànimo:

-Ací vull pendre martiri davant la magestat vostra e retre l'esperit, e tendré la mia mort per ben spletada (cap. 262; Martorell, 2005: 981).

Hipòlit canvia el gest covard d'Herodes per un altre en aparença valent, però igualment ridícul: pretendre defensar l'Emperadriu amb l'espasa quan l'ús de l'arma hi és absolutament inútil. Hi havia cohesió, al teatre medieval, entre l'Officium Stellae, que està a la base de la representació d'Herodes, i la representació de La matança dels innocents o Degolla, a la festivitat del Corpus. Al drama, la tramoia havia de fer que l'estrella, a la qual s'al.ludeix constantment en les acotacions, es desplacés a l'escenari. I Herodes faria servir la seua espasa, primer per amenaçar l'estrella que guia els Reis i després per intentar suïcidar-se i, en penedir-se, oferir l'espasa per a la «degolla».

Estrelles, espases, llits, cambres, retrets, terrats...; atrezzo, decorats, espais, acció dramàtica... Gestos ampul.losos i teatrals fan que Herodes, com Judes, puga ser una presència latent en aques- 
ta mena de Judici Final, on actua el duc de Lencastre com un Caront o un Radamant pompós que hagués de presidir el tribunal que jutja els esperits dels difunts i decidir sobre la sort dels pecadors, penjats o degollats condemnats a l'Infern dels més perversos i inics.

\section{El Gran Tamerlà i l’aplicació tirànica de la justícia contra els oficis}

El viatge dels ambaixadors del rei Enric III de Castella a Samarcanda, entre 1403 i 1405, per tal d'establir contactes polítics amb Temur Lenk o Tamerlà, va constituir una de les majors empreses diplomàtiques de contacte europeu amb l'imperi mongol de tot l'Occident medieval, i va romandre reflectit dins un important llibre de viatges, l’anomenada Embajada a Tamorlán (González de Clavijo, 1999).

Quan els ambaixadors del rei de Castella són a Samarcanda, relaten com es produeix un trasllat -una mena de fira o mercat obligat per l'Emperador- de comerciants i venedors als afores de la ciutat. Quan llegim aquestes pàgines, no ens trobem gens lluny del que podria passar en una altra ciutat de les corones aragonesa o castellana, o europea.

E por mayor alegría el Señor mandó pregonar por toda la ciudad de Samarcante que todos los oficiales de la ciudad, assí los que vendían paños como aljófar, e cambiadores e todas las otras cosas e mercadurías e cosas que podían ser, e cozineros e carniceros e panaderos (e carpinteros) e alfayates e zapateros e todos los otros ministrales que en la dicha ciudad estavan, fuessen allí al campo donde él estava con su ordo, e pusiessen todas sus tiendas e vendiessen allí lo que tuviessen, e no en la ciudad. E otrossí que cada un oficio hiziessen un juego con que anduviessen por su ordo por que las gentes tomassen plazer, y que dende no partiessen sin su licencia e mandado. Por el qual pregón salieron todos los oficiales $^{72}$ de la ciudad con todo lo que tenían que vender e con sus menistriles ${ }^{73}$, e poblaron el ordo, cada oficio de por sí por sus calles señaladas, que les dieron ordenadamente, lo de cada oficio a su parte. E de cada oficio traxieron su juego, con que andavan haziendo solaz por todo el ordo. (Embajada, 1999: 282)

Es parla de venedors de teixits o teles i perles, i després de «cozineros e carniceros e panaderos (e carpinteros) e alfayates ['sastres'] e zapateros e todos los ministrales que en dicha ciudad estavan». No dubtem que els menestrals de Samarcanda tingueren les seues diversions, balls, jocs o «entremesos», però tampoc no dubtem que el relator hi trasllada una imatge que ha vist en alguna ciutat castellana. En dues ocasions, dins la mateixa citació, es refereix al tema: «que cada un oficio hiziessen un juego ['entremés'?] con que anduviessen por su ordo por que las gentes tomassen plazer», i, aleshores, «cada oficio traxieron su juego, con que andavan haziendo solaz por todo el ordo». El relat és sorprenent, tot i que versemblant i fins i tot familiar per les similituds amb les mostres castellanes. Però tot el que segueix és absolutament inesperat i una mica incomprensible:

E a do estos dichos oficiales pusieron sus tiendas, que eran muchas e diversas maneras, allí mandó el Señor hazer muy muchas horcas, por cuanto en aquellas fiestas que quería hazer,

\footnotetext{
72. Quan parla de «oficiales» dues vegades, crec que potser un error de transmissió textual, perquè clarament s'està referint a «oficios», que apareix altres dues vegades dins el mateix paràgraf.

73. Unes línies amunt parla de «ministrales». Però ací es refereix a músics o «menestriles».
} 


\begin{abstract}
dixo que entendía a unos hazer bien e merced, e a otros mandar enforcar. E la primera justicia que hizo fue en un su alcaide mayor, que ellos llaman dina ['juez'], que era el mayor home que en todo el imperio de Samarcanda avía, el cual avía él dexado en aquella ciudad cuando dende partió por su alcalde mayor, podía aver seis años e onze meses (en el qual tiempo aquel su alcalde dizen que usó mal del oficio); e mandólo venir ante sí, e luego súbito mandólo enforcar e tomar todo lo suyo. E con esta justicia d'este gran home fue toda la tierra en gran espanto, por quanto era home de quien él mucho fiava. E otro que (librava) por este dicho alcaide mandó (d'él) fazer essa mesma justicia. E un privado del Señor que llaman Burodo Mirassa demandó merced al Señor por aquel, que lo perdonasse e que le daría cuatrocientos mil pesantes de plata, que es cada pesante un real de plata. E el Señor dixo que le plazía. E desque ovo levado d'él la moneda, madólo atormentar, que diesse más. E al cabo, desque no pudo d'él más aver, mandólo enforcar por las piernas fasta que murió.

E otrosí fizo justicia de un gran home a quien dexó tres mil cavallos en guarda cuando de aquella tierra partió, e porque agora no los tenía todos, mandólo enforcar; e no le valía que dezía que no tres mil, mas que le daría seis mil si le diesse espacio. E d'esto e de otras cosas mandó el Señor fazer justicia.

E otrosí mandó fazer justicia de ciertos tenderos porque avían vendido la vianda más de cuanto valía cuando él allí llegó; otrosí, de zapateros e borzeguineros e de otros oficiales, por quanto vendían caras las cosas. E por esto se recelavan los de la ciudad que no les avía fecho salir fuera con sus tiendas, sino por les mandar robar. E la su usança d'ellos es de cuando fazen justicia de algún home de honra, mándalo enforcar, e del home de baxo estado, degollar. E cuando a alguno degüellan, tiénenlo a gran mal, e a baldón lo han ellos (Embajada, 1999: 282-283; els subratllats són nostres).
\end{abstract}

La paraula clau, que hem subratllat al passatge, és «justícia». Es farà justícia, però una justícia ben singular, palesament i paradoxalment injusta. Es tractaria de mostrar uns actes que podríem resumir o condensar com de comportament no només autoritari i injust, sinó cruel fins a l'absurd, per part d'un monarca dèspota, com era evidentment el Gran Tamerlà, però que sempre havia sigut tractat amb tota diplomàcia i degut respecte que li corresponia per part del o dels ambaixadors. Tanmateix, s'hi trenca aquest respecte, perquè Tamerlà apareix ara reflectit com un autèntic tirà de l’Antiguitat, com el Neró cruel de la tradició historiogràfica, dels exemples alliçonadors del Recull que hem examinat (8.2), així com del teatre o de la tradició oral medieval.

Llegim que el sorprenent càstig en sèrie de Tamerlà -una mena de venjança- va ser fer construir moltes forques per, diguem-ne, alegrar les festes: «dixo que entendía a unos hazer bien e merced, e a otros mandar enforcar» ${ }^{74}$. Comprovem com la primera «justícia» va ser manar enforcar al seu «dina» o governador -una mena de primer ministre-, home de total confiança que Tamerlà havia deixat set anys abans per fer-se càrrec de l'Imperi i que hauria actuat amb prevaricació, segons rumors («dizen que usó mal del oficio»). Però una segona «justícia» va ser manar enforcar també, tot seguit, un home de confiança de l'anterior. Una tercera «justícia», enforcar igualment un «privado» (un tal «Burodo Mirassa») que havia gosat intercedir per l'anterior, demanant-ne el perdó amb un bon rescat. Una quarta «justícia», contra un malversador de cavalls. I, en roda ja imparable, també va fer-ne més, de «justícies», però ja no contra alts càrrecs,

74. Recordem que en l'episodi de Tirant, aquesta alternativa ( «a unos... a otros...») està unificada, i els sis juristes seran enforcats «per fer-los molta honor», és a dir, irònicament, per fer-los «bien e merced»: «féu posar dues forques ben altes e féu penjar tres juristes en cascuna, cap avall per fer-los molta honor». 
sinó contra simples comerciants (venedors) o sabaters, per haver venut suposadament massa cars els seus productes.

Quin sentit té aquesta massacre encadenada de gent en principi innocent (o no palesament culpable, si més no als ulls senils de l'Emperador)? Ens trobem, el mateix que passa a l'episodi de Tirant, davant una aplicació de la justícia en primer lloc improvisada i inesperada, després abusiva, despòtica i cruel, i, a més a més, sense trellat ni seny. Però a l'episodi de l'Embajada castellana trobem, a més a més, altres elements comuns amb l'episodi del Tirant que no podem deixar passar per alt, començant pels personatges protagonistes -com ara són el jutge arbitrari (en aquest cas, Tamerlà), les víctimes innocents (entre tots, els menestrals són els més injustament i arbitràriament castigats)-, seguint per l'espai i temps especials per a les execucions (la fira fora de la ciutat i el temps de festa i mercat) i acabant per les forques posades com un càstig exagerat $i$ humiliant. Observem finalment que aquesta humiliació es torna absolutament irracional quan el penjament es fa boca cap per avall. A Burodo Mirassa, el privat, després de sotmetre'l a turment, «mandólo enforcar por las piernas fasta que murió». Els juristes, al Tirant, també són penjats cap avall: «féu penjar tres juristes en cascuna, cap avall». I també fins a la mort («...fasta que murió»), perquè, com diu el text del Tirant, el duc de Lencaster no se n’anà fins que moriren: «no.s partí de allí fins que agueren tramés les miserables ànimes en infern $\gg$. I recordem els casos anteriorment vistos de condemna $(\$ 7)$.

Finalment, recordem que el duc, al Tirant, havia decidit resoldre la baralla entre ferrers i teixidors, defesos pels juristes d'un bàndol i l'altre, traient «fora de la ciutat» els sis juristes: «Lo duch se mès enmig de la pressa de tota la gent e pres sis juristes, tres de cascuna part, e tragué.ls fora de la ciutat. Ells se pensaren que lo duch los volia per demanar quala part tenia millor justícia». L'Emperador Tamerlà fa el mateix, des del moment que trau fora de Samarcanda, i porta a territori extramurs (in-civilitzat, extra civitas), amb l'excusa de la fira de mercat, els personatges sobre els quals vol exercir la seua justícia. De manera que al remat tots sospiten si la celebració de la festa fora de la ciutat no ha sigut un acte premeditat: «E por esto se recelavan los de la ciudad que no les avía fecho salir fuera con sus tiendas, sino por les mandar robar».

\section{Entre entremesos i rondalles}

Quan l'exageració frega els límits de la inversemblança i es fa relat curt al Tirant, sol fer-ho de dues maneres: o bé com a «entremés», o bé com a conte o rondalla; també, en menys casos, com a novel.lino o paròdia històrica. Massip ha estudiat els entremesos de la novel.la en relació amb els rerefons dels espectacles a la corona d'Aragó. Més que episodis fantàstics, que és com els cataloga i enquadra, per exemple, Vargas Llosa, els entremesos són definitivament «artificis» on l'autor introdueix, de vegades amb molta fidelitat, alguns dels múltiples fastos habituals en les corts europees de l'època. Parlem de l'episodi de les magnificències de la Roca, seguit de la desaparició màgica del déu Amor (tots dos durant les festes d'Anglaterra) ${ }^{75}$; de l'arribada de Morgana a Cons-

\footnotetext{
75. Vegeu Massip (2010: 153-158). Les magnificències de la «roca» de Tirant (it. roche, fr. charriot, angl. ben estudiades com a fastos per Oleza (1992), deriven certament de la roca -molt probablement imaginada per Enric de Villena- que es va construir per a les festes d'entrada del rei Ferran I a Saragossa, en 1414. El pare de Martorell, Francesc Martorell, cambrer de Martí l'Humà i jurat de València (a partir de 1412), hagué de conèixer-la, donat que la seua ciutat havia de preparar una altra entrada de celebració semblant. El castell d’Amor no només com allegoria (Pérez González, 2016), sinó també com a roca, es donava en altres àmbit europeus, que tenim testimoniats gràficament.
} 
tantinoble, amb la presència del rei Artús ${ }^{76}$; de l'episodi de les llesques de pa a la cort de Sicília ${ }^{77}$; i del que Grilli anomena «entremés del Moro Lauseta», que forma part del parany que la Viuda Reposada va preparar a Tirant, fent-li creure que Carmesina mantenia relacions amb l'hortolà de palau ${ }^{78}$. A més a més, hem pogut comprovar com la desfilada de l’entrada del rei anglés, on es dona la divisió d'oficis, tot i que no és un entremés, sí que és un contenidor potencial d'entremesos, si mirem la història de la corona d'Aragó (Fig. 12).

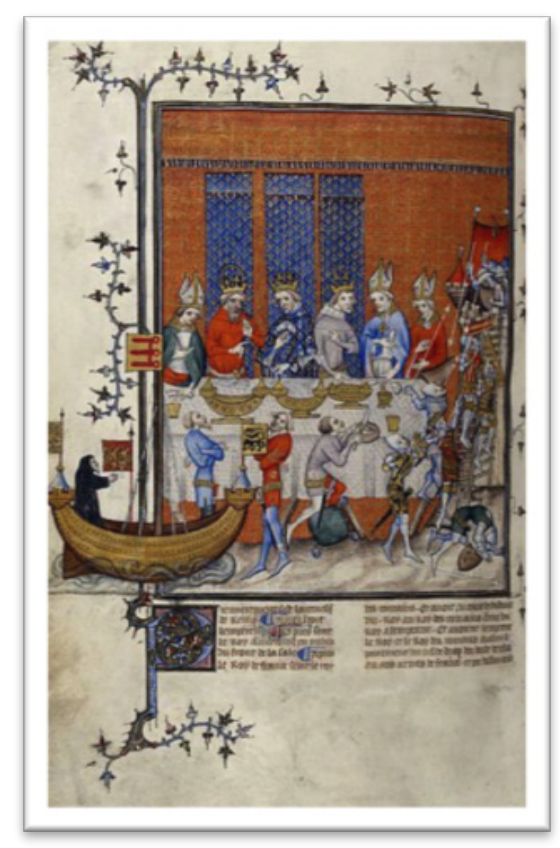

Fig. 12. Entremés sobre la conquesta de Jerusalem, a la cort de Carles V de França. BNF, Fr. 2813, fol. 473v

La ficció escènica tenia, sens dubte, enorme poder d'eixarm. Donades les creences en l'estrany o sobrenatural que tenia l'imaginari medieval, tan diferents de les nostres, estem caminant sempre, com diu Massip, en les «tènues fronteres entre realitat i ficció». I si els artificis de la ficció escènica són sovint percebuts, a l'edat mitjana, com a esdeveniments reals o possibles, els d'aquella mateixa ficció escènica però inclosa dins la ficció novel-lística poden produir des de confusió fins a desconcert. Només des del desori s'entén un passatge essencial per a la interpretació del sentit de la versemblança en la novel.la, quan el cavaller Tirant, en veure els combats escènics -ficció preparada- en la roca del déu Amor, diu: «los qui no u sabíem, pensam, en lo primer combat, que anava de veres, e mols descavalcam e, ab les spases en les mans, cuytam allà; emperò prestament coneguem que era burla» (cap. 53; Martorell, 2004: 225). De la mateixa manera, al final de l'episodi d'Artús i Morgana, diu Martorell que tots «staven admirats del que havien vist, que paria que tot fos fet per encantament» (cap. 202; Martorell, 2004: 825). 
Podríem tenir la temptació d'afegir-hi l'episodi de la disputa entre els oficis com un altre entremés inclòs al Tirant. Tanmateix, i tot i que que hem comentat entremesos documentats a Tarragona on els teixidors i els ferrers en preparen relacionats amb la lluita entre el bé i el mal, i en concret entre sant Miquel i els diables (Fig. 7 i Fig. 8), hem de descartar aquesta hipòtesi. En tot cas, el marc extern de l'episodi, la desfilada que enquadra un episodi intercalat, semiautònom i trencador amb els límits de la versemblança (les «tènues fronteres entre realitat i ficció») que adopta la resta de la novel.la, sí que pot arribar a considerar-se com un contenidor d'entremesos o escenificacions burlesques. Però ni els personatges de l'episodi de la disputa, ni els motius, ni la impossible teatralització (donat el protagonisme de la multitud, i els espais oberts i no tancats per a l’acció) són característiques que es poden adscriure a l'entremés, tot el contrari. I tampoc són trets característics de la facècia o l'anècdota.

Tant els personatges com el tema -individualitzat, però amb sentit universal-, el to satíric i les circumstàncies podrien ajustar-se molt millor, en canvi, als requisits genèrics d'un conte, a cavall entre l'exemple moralitzant o el conte didàctic (com el de Neró que hem vist del Recull) i la mirada tantes vegades riallera de la rondalla folklòrica. Una rondalla narrativa de teixit lletrat, això sí, feta escenificar dins la ficció. La resolució de la història, amb la figura justiciera del duc de Lencastre i la ratificació del domini dels forts sobre els dèbils, ens remet a la mitologia cristiana (sant Miquel i els dimonis) o a la moralització amb triomf aristocràtic (com ara la dels contes d'El conde Lucanor), però el nus del relat, amb els equívocs sobre les decisions de la justícia que relativitzen el seu funcionament, és propi d'algunes rondalles tradicionals, com veurem a continuació. Fet i fet, estem acostumats a comprovar que Martorell és agosarat i radical a l'hora de transformar al seu gust la matèria que rep, siga històrica, literària o espectacular. I la seua radicalitat, en aquest cas (però no és l'únic a la novel.la), comença per la inserció del conte dins un context pseudohistòric com el de l'entrada reial.

Aquesta inserció d'exemple o rondalla dins el relat no seria excepcional a la novel.la. Si el Quijote, com qualsevol llibre clàssic extens, conté novel-les curtes, i patrons de contes i rondalles intercalats, el Tirant presenta també traces de contes o rondalles intercalades, a més de motius folklòrics diversos. La tradició de la matèria de Bretanya ho permet i ho facilita. L'episodi de la princesa Ricomana de Sicília, la princesa que no sabia l'endevinalla, és potser la més notòria d'aquestes intercalacions, pel que fa a motius folklòrics ${ }^{79}$. Però també l'episodi d'Espèrcius a l'illa de Lango sembla tret d'una rondalla meravellosa de dracs i princeses. Igualment, el conte de la vinya que conta Hipòlit, tot i que no és versió cabdal d'ATU, 471, té un rerefons clarament folklò$\mathrm{ric}^{80}$. I una figura com la d'Escariano, negre i gairebé gegant, ens recorda, més que els gegants del llibres de cavalleries o de l'èpica, els personatges de rondalla relacionats amb el tipus ATU, 301, The Strong Man and his Companions, que remunten al Samsó bíblic ${ }^{81}$.

Tot i la restricció sobre la figura aristocràtica del duc, abans comentada, si haguéssem de plantejar un esquema d'argument per al nostre episodi, no seria molt diferent del d'una rondalla tradicional. I podria ser aproximadament el següent:

[A] Dos reclamants en disputa acudeixen a resoldre el seu conflicte davant l'autoritat establerta. [B] Aquesta autoritat legal demostra la seua inutilitat i agreuja el conflicte, en lloc de so-

79. Vegeu Beltran (2006a: 202-218; 2006b).

80. Vegeu Renedo (2019) per a la més recent i completa interpretació del conte, on confirma com a font principal un exemplum de Bernardino de Siena.

81. Vegeu Beltran (2006a: 218-219). 
lucionar-lo. [C] Una altra autoritat inesperada, en principi no acreditada, hi aporta una solució, sorprenent i il.lògica, però al capdavall eficaç.

Els protagonistes del conflicte -el conflicte que sempre formula una rondalla- serien, en aquest cas: $[\mathrm{A}]$ els reclamants (els ferrers i els teixidors), [B] l'autoritat primera (els juristes) i [C] l'autoritat segona o substitutòria (el duc, emparat pel rei). I l'objecte principal i més significatiu -atribut identificador- en seria l'eina del càstig: la forca.

Donats aquests pressupostos argumentals, comprovem si és possible trobar-ne, de relats semblants, al si de la tradició de rondallística catalana, hispànica o universal.

\section{Decisions injustes però intel.ligents: ATU 1534}

El tema de la justícia aplicada «injustament», o arbitràriament, però a més a més amb descrèdit dels intermediaris (els juristes o jutges), ens remet directament a l'àmbit d'una sèrie de rondalles relacionades amb les decisions injustes i paradoxalment intel.ligents. I entre aquestes destacarien, en primer lloc, les rondalles al voltant dels judicis de Salomó. En principi, semblaria que tota la sèrie de rondalles sobre aquests famosos judicis coincideix almenys amb dos dels motius principals del relat: la difícil querella plantejada i la solució inesperada i sorprenent (justa o injusta) del jutge. L'esquema d'ATU 926, Judgement of Solomon, és ben conegut, donat que ve de l'Antic Testament (Reis, III, 16-28):

Two women both claim a child. The judge Solomon offers to cut it in half. One of the women refuses (lets go when the child is to be torn asunder, tries to stop the judge from cutting it) and is therefore determined to be the real mother ${ }^{82}$.

Sancho Panza és potser el jutge salomònic popular per excel-lència, i de fet el seu procés d'adaptació a la figura de governant ha sigut estudiat com a paròdia carnavalesca de l'ascens del rei David al relat bíblic (Campos y Herrera, 2006). Sancho, una vegada encarregat de la governació de l'«ínsula» Barataria, es troba dins una tradició que per a una sèrie de crítics és essencialment rondallística (Chevalier, 1989), però per a altres bàsicament carnavalesca, és a dir, de món a l'inrevés (Redondo, 1978). I, com comenta Redondo, aquesta tradició va lligada a jocs de tribunals carnavalescos:

En época de Carnestolendas, existía el llamado 'juego del tribunal' [...], en que aparecían un presidente, un relator, varios abogados, etc. y cuya finalidad era reírse de los desaprensivos inocentes. Pero, sobre todo, en dicha época del año ( $y$ en otras) se constituían tribunales populares paródicos que, remedando la pompa de la Justicia ordinaria, censuraban burlescamente los hechos atentatorios contra las costumbres normales y particularmente las que estaban relacionadas con la moral sexual... [...] ... había en Francia una tradición de causas burlescas que, al principio, juzgaban paródicamente los jueces y letrados del Palacio de Justicia de París (la Basoche) y de otras ciudades, principalmente en Carnaval (1978: 60-61).

Un ambient carnavalesc, fins i tot un possible «joc de tribunal» (el «divís» entre ferrers i teixidors), no deixa d'estar present en la desfilada del Tirant, que recordem que acaba amb la presèn- 
cia «alliberada» de monges de clausura, al costat de prostitutes (certament, el món a l'inrevés). Sancho s'enfronta, per la seua banda, quan és governador a l'«ínsula», amb tres litigis judicials, més altres secundaris, que resol intel.ligentment i sorprenentment. Els querellants en són sempre gent humil. I així, al primer cas, «El pleito del sastre», hi ha dos protagonistes senzills, el sastre (o teixidor menestral) i el seu client, els quals tenen una baralla sobre un problema estúpid, però que realment planteja un dilema ${ }^{83}$. La sentència de Sancho serà salomònica i justa: en contra dels dos, per ser tots dos estúpids. Ara bé, si tenim com a referència el judici (o no-judici) del Tirant, mancaria, com succeeix també als altres casos de judicis de Salomó, la mateixa substància o base de l'episodi: el descrèdit dels juristes. El comportament de Sancho com a «jurista» improvisat no desacredita el paper de la justícia, tot i que trasllada irònicament la responsabilitat d'exercir-la a l'home senzill, inculte i sense més preparació jurídica que el sentit comú.

Si pensem que es relaciona amb el món de la rondalla, haurem de buscar el nostre argument al si d'altres dominis rondallístics més propers que els del món de Don Quijote. El tema de rondalla al voltant de la justícia aplicada «injustament», literalment o exageradament i, sobretot, no amb seny (com fa Sancho), sinó sense trellat, està directament relacionat amb la sèrie de les DECISIONS INJUSTES / INTEL-LIGENTS, que coincideix amb els tipus internacionals ATU, 1534, Series of Clever Decisions. (The Decisions of Shemjaka), 1534A, The Innocent Man Condemned to Death, 1534A*, Barber Sustituted for Smith at Execution i 1534D*, Sham Dumb Man Wins Suit; o també relacionades amb les decisions absurdes, que constituirien amb diferents variants el tipus miscel.lani $1634 Z^{*}$, Other Absurd Decisions. Tots aquests tipus tenen alguna versió hispànica, $\mathrm{i}$ alguns en tenen de versions catalanes.

El primer d'aquest tipus, ATU, 1534, Series of Clever Decisions. (The Decisions of Shemjaka) ${ }^{84}$, presenta tot un grup d'episodis que poden donar-se o bé exempts o bé en seqüència ${ }^{85}$. Alguns d'aquests episodis tenen versions en les tradicions europees, incloses les hispàniques ${ }^{86}$. En la tradició catalana, en concret, el tipus 1534, El jutge exigent, compta amb versions al Principat, a Ma-

83. En resum: un home acudeix a un sastre i li demana fer una caputxa (un barret) amb una mesura de tela. Quan rep resposta positiva, dubta de l'honestedat del sastre i comença a insistir-li per veure quantes caputxes pot traure d'una mesura que evidentment només arriba per una. Acorden que en farà cinc caperutxes, però el dia del lliurament el sastre lín presenta cinc diminutes, una en cada dit de la mà. La sentència de Sancho és que, per tramposos, tot dos perden diners i treball. (II, XLV; Cervantes, 1998: 993). N’hi ha versions orals tradicionalitzades.

84. Vegeu Khazaie (2017).

85. «A poor man (merchant, baker) causes a series of accidents: / [1] He pulls off the tail of a (borrowed) horse (one of two oxen that he has borrowed dies). The owner sues him. / The poor man flees into a house and frightens (hits) a pregnant woman so that she miscarries. Or a woman invites him in out of the rain, and he sits on her sofa and accidentally kills her child. Her husband (the woman) sues him as well. / [2] Out of desperation, the poor man jumps from a high tower (bridge) and kills a passer-by [N320, N330], whose brother (other relative) sues him. / The injured parties bring the poor man before a judge. The judge decides as follows [J1173]: / The poor man should keep the borrowed horse until its tail grows back. / He should impregnate the mother with another child (and her husband should hit her again, to give her another miscarriage). Her husband rejects this settlement and withdraws his suit. (In some variants, he has to pay a fine to the poor man.) / The brother (other relative) of the killed man should jump from the tower upon the poor man to kill him. He also withdraws his suit. (In some variants he also has to pay a fine to the poor man.) / (The poor man leaves with the horse and his settlements.) / Some variants have a frame tale: the judge persuades a baker (merchant) to give him a goose (duck) that belongs to someone else. He promises to protect him if the owner of the goose accuses him of theft. Then as above» (Uther, 2004, II: 264)

86. Vegeu l’asturiana, que replega Suárez López (1998, no 82): «...chega el del puente, dice: / Tiróuse [encima] da mujer y qué sé you qué. / ¡Que se ponga él debajo y tírese usté encima dél! / ¡Cualquiera se tiraba! Saléu ben... ». Insuela (1992) estudia la tradició hispànica del tema. 
llorca, a Menorca, a Eivissa i al País Valencià. Comprovem-ho amb els números ([1] i [2]) en comú amb el tipus internacional ( $c f . n .85)$ :

Un home causa una sèrie de perjudicis involuntaris: [1] el bou que li han deixat es trenca una banya, arrenca la cua d'un ruc que el vol treure del fangar $[c f . \ll$ He pulls off the tail of a (borrowed) horse»], [2] cau d'un pont i mata un home que hi ha sota, etc. [cf. « Out of desperation, the poor man jumps from a high tower (bridge) and kills a passer-by»]. Un jutge resol els plets que li posen de manera justa encara que cadascuna de les decisions pugui semblar absurda: l'home s'ha de quedar el bou fins que li creix la banya,no ha de tornar el cavall fins que li hagi crescut la cua, s'ha de posar sota un pont perquè hi saltin des de dalt i provin de matar-lo, etc. Com que veuen que hi surten perdent li retiren els plets (Oriol i Pujol, 2003: 308).

«The Decisions of Shemjaka», el subtítol que li dona Uther a aquest tipus ATU, 1534, es refereix a un personatge típic del folklore rus, però la seua tipologia coincideix amb la d'altres jutges molt populars, des de la tradició de l'Índia fins a l'hebrea (al Mishná, la tradició oral corresponent del Talmud jueu) i també islàmica.

Pel que fa al segon tipus, ATU, 1534A, The Innocent Man Condemned to Death, el seu contingut remet igualment a les accions desastroses involuntàries, que condueixen a un judici on un jutge suposadament imparcial condemna injustament, però a favor del pobre diable causant de les destrosses ${ }^{87}$.

Dins aquest tipus també són molt populars en la tradició oriental, àrab i hebrea, els contes del jutge Karakush o Karakash, en la línia de la tradició de Shemjaka, que acabem d'esmentar. Un exemple palestí, protagonitzat per un reclamant menestral, de nou un teixidor, que acudeix a Karakash, coincidiria perfectament amb el primer membre de la cadena dins el tipus ATU, 1534A que hem citat: «A thief tries to break into a House at night but is killed when the wall collapses... ${ }^{88}$.

87. «A holy man and his disciple come to a city where the king and all his ministers are fools, and where all kinds of food are sold for the same price [J342.1.1, X1503.3]. The holy man leaves at once ad warns his disciple to do so too, but the disciple stays despite the warning [N347.7]. / A thief tries to break into a house at night but is killed when the wall collapses...».

88. «Un teixidor, que tancava la seua botiga durant la nit, va deixar una llarga agulla enganxada al seu treball al teler. Un lladre va entrar amb una falsa clau i, mentre es trobava embolicat en la foscor, l'agulla li va treure un dels ulls. Va tornar a eixir i va tancar la porta al darrere. Al matí següent va explicar la seua història a Karakash, el jutge imparcial, que va enviar a cridar al teixidor, va mirar-lo severament, i va preguntar-li: -Vosté va deixar una agulla d’embalar al drap del teler quan va tancar la botiga ahir a la nit? / - Sí. / - Bé, aquest pobre lladre ha perdut l'ull per la seua descurança. Va anar a robar la vostra botiga, va entropessar i l'agulla li va traspassar l'ull. No sóc jo Karakash, el jutge imparcial? Aquest pobre lladre ha perdut un ull per la vostra falta, així que perdreu un ull de la mateixa manera. / - Però, senyor -va dir el teixidor-, ell va venir a robar-me. No tenia cap dret. / - No ens preocupa el que va venir a fer aquest atracador, sinó el que va fer. La porta de la botiga s'ha malbaratat aquest matí o hi ha faltat alguna cosa? / - No. / - Llavors no us ha fet cap mal, i no feu més que afegir-hi insults a les seues lesions, tot reprotxant-li la seua forma de vida. La justícia demana que perdes l’ull. / El teixidor va oferir diners al lladre, al Kadi [Karakash], però en va. El jutge imparcial no anava a canviar d’opinió. Al final, un pensament brillant va colpejar el teixidor, i li va dir: / - Ull per ull és la justícia, oh senyor meu, Kadi; però, en aquest cas, no és bastant just per a mi. Tu ets el jutge imparcial, i em sotmetré la teua decisió, tot i que jo, casat i amb fills, pairé més danys en la pèrdua d’un ull que aquest pobre atracador, que no té ningú depenent d'ell. Ara bé, com puc seguir teixint amb un sol ull? Tanmateix, tinc un bon veí, un armer, que és un home solitari. Que li traguen un dels seus ulls. Per a què vol ell els dos ulls per a comprovar els canons de les seues armes, si amb un ull en té prou? / El jutge imparcial, colpejat davant la justícia d’aquests arguments, va fer cridar l'armer i va fer que li tragueren un ull» (J. E. Hanauer, Folk-Lore of the Holy Land: Moslem, Christian, and Jewish (London: The Sheldon Press, 1935, pp. 93-95; apud Ashlim; la traducció és nostra, a partir de l'anglés). En un altra rondalla, de la mateixa sèrie, un fuster que treballava en la construcció d'una casa va patir un accident quan va caure una pedra i li va trencar una cama. Es va queixar a Karakash, el jutge imparcial, que va trucar al senyor 
ATU, 1534D*, Sham Dumb Man Wins Suit, té un parell de testimonis excepcionals dins la tradició catalana (de Joan Amades i Pau Bertran), els únics que jo conec de tota la tradició peninsular hispànica. Com hem comentat abans, aquesta rondalla podria tenir relació $\mathrm{amb} \ll \mathrm{El}$ pleito del puente» que se li presenta a Sancho Panza (vegeu \ 6). Oriol i Pujol anomenen aquest tipus $1534 \mathrm{D}^{*}$, L'acusat atabala el jutge, i el defineixen:

Un home manlleva el ruc d'un veí per anar a un altre poble a resoldre un assumpte. Pel camí el ruc cau per un precipici i es mata. Com que l'home no pot comprar un altre ruc al veí van a veure el jutge. L'home explica el cas d'una manera tan enrevessada que atabala el jutge i decanta la sentència a favor seu (Oriol i Pujol, 2003: 308).

\section{La justícia d’Almudévar}

Però el que més familiar ens pot resultar, en relació amb l'episodi de la divisió entre els oficis, és ATU, 1534A*, Barber Sustituted for Smith at Execution, diferenciat per Uther, tot i que en realitat és una especificació de l'anterior. El catàleg internacional el defineix:

A smith commits a crime and is condemned to death. The villagers complain to the judge [mayor] that they cannot manage without the smith. They ask him to execute a barber instead, because they have two of those [J233.1.1].

El tipus té un limitat nombre de versions. Està catalogat en anglés, en castellà, en Alemanya, Àustria, Hongria, Croàcia, Polònia o Estats Units. Aquesta expansió limitada podria venir -es suposició meua- per un origen jueu, donat que es cataloga en la tradició jueva i en països amb aquesta tradició. En castellà, la tradició oral ha sigut estudiada fonamentalment per Chevalier (1983, núm. 170; 1999: 195) i pels crítics de la novel.la que comentarem tot seguit.

Perquè el principal testimoni hispànic és un conte i tema tradicional, «La justícia d'Almudévar», que té la versió més ben i llargament desenvolupada dins una de les obres principals de la literatura aragonesa del segle XIX, la novel.la Vida de Pedro Saputo (1844) de Braulio Foz (1791$1865)^{89}$. El conte, però, és més antic i remunta a facècies i anècdotes replegades ja als segles XVI i XVII ${ }^{90}$. El text de la novel.la de Braulio Foz diu:
El herrero un día se enfureció contra su mujer porque le llevó el almuerzo frío; y tomando un hierro que estaba caldeando en la fragua se lo metió por la boca y la garganta, expiran- do la infeliz en brevísimo rato. Era el herrero hombre muy estrafalario... [...]. Prendiéron- le inmediatamente, y puesto en la cárcel con muchas cadenas al cuello y cepos a los pies, le juzgaron aquel mismo día y le condenaron a muerte; cuya sentencia iba a ejecutar otro

\footnotetext{
de la casa i el va acusar de negligència culpable. El propietari va acusar al constructor; el constructor a una noia que passava per allí amb un vestit roig tan brillant que li va enlluernar; ella va acusar el venedor draper que li havia venut el vestit. Finalment, Karakash va encomanar la culpa al venedor i va manar penjar-lo del llindar de la seua casa, però com que era tan alt i el llindar era baix, no el podien penjar. Aleshores, Karakash va manar penjar el primer home baixet que trobaren. Per al personatge de Karakush, vegeu Schwarzbaum (1968: 252-254). La relació entre contes folklòrics sobre jutges i actuació real de la justícia, des de l'Edat Mitjana fins el segle xx, està molt ben estudiada per Cover (1985).

89. Destaquem Ynduráin (1986), Mainer (1989) i Amores (1993), entre una àmplia bibliografia.

90. Les anècdotes sobre Pedro Saputo, i sobretot aquesta de «la justícia d'Almudévar», s’han fet tan populars que han convertit Saputo en gairebé un epònim del municipi d’Almudévar (a la província d'Osca).
} 
día. Ya estaba la horca levantada y todo el pueblo en la plaza aguardando la ejecución; ya le sacaban y llevaban al patíbulo, cuando subiendo uno del pueblo a caballo encima de los hombros de otro dijo: «Qué is a fer, hijos de Almudévar? ¿Conque enforcaréis a o ferrero que sólo tenemos uno? Y ¿qué faremos después sin ferrero? ¿Quién nos luciará as rellas? ¿Quién ferrará as nuestras mulas? Mirad lo que m'ocurre. En vez de enforcar a o ferrero que nos fará después muita falta, porque ye solo, enforquemos un teisidor que en tenemos siete en o lugar e por uno menos o más no hemos d'ir sin camisa». - ¡iTiene razón!, ¡tiene razón!, gritaron todos; ¡enforcar un teisidor!, jun teisidor!..., ¡un teisidor!... Y sin más que esta voz y grito cogen al primero de ellos que toparon por allí, le llevan a la horca, le suben y le ahorcan, y ponen en libertad al herrero (Ynduráin, 1986: 260-261).

L'anècdota, que Braulio Foz reutilitza i refà, era recollida en primer lloc per Melchor de Santa Cruz (1505-1585), dins la seua Floresta española (1574):

\begin{abstract}
Mató un herrero en un lugar a un hombre y fue condenado a ahorcar. Juntáronse los más del lugar y fueron a decir al alcalde que no permitiesen que lo ahorcasen, porque era muy necesario al pueblo, que no podían pasar sin herrero para hacer las rejas y azadas y herraduras y otras muchas cosas. Preguntó el alcalde: ¿Cómo puedo yo dejar de hacer justicia? Respondió un labrador: Señor, en este lugar hay dos tejedores de paños, para un lugar tan pequeño como éste basta uno; ahorquen al otro.
\end{abstract}

Anys després de la versió de Floresta española, Gonzalo Correas, al seu Vocabulario de refranes... (1627) la va relacionar amb el refrany: «Al barranco de la Violada, qui con forca, qui con pala», que el lexicògraf va prendre d'un Libro de refranes de $1549^{91}$. No hi ha encara, en aquestes dues versions primerenques, atribució del fet al lloc d'Almudévar i no hi figura cap altre topònim. Dos segles després, Braulio Foz introduirà, a més d'aquest topònim, la variació que el crim fos matar el ferrer a la seua dona tot ficant-li per la boca un ferro candent, perquè li va portar l'esmorzar fred. Una barbaritat que no fa - per descomptat- ni més lògic ni més justificat l'assassinat, sinó més culpable i criminal al ferrer i, per tant, fins i tot més absurda la proposta de perdonar-li la vida.

En conseqüència, al si de l'anècdota de Melchor Santa Cruz tenim una sèrie d'elements comuns amb l'episodi de Tirant (que després es ratificaran dins l'episodi de Pedro Saputo). Aquests elements els podríem enumerar i dividir en cinc clàusules principals: [1] els personatges del ferrer (ací es un només) i els teixidors; [2] el personatge del jutge primer (alcalde) inútil o inoperant; [3] la necessitat d'aplicació de la justícia i l'instrument de càstig: la forca; [4] l'aplicació destrellatada o desraonada de la justícia; [5] la conclusió implícita: el jutge segon (el llaurador) és estúpid o boig. I, a més a més, una sisena clàusula final, reticent i irònica: [6] la proposta de solució és beneita, delirant i cruel, però... té una certa lògica.

Aparentment, mancaria un element o motiu fonamental, que és el que en gran part substancia l'episodi de Tirant: el fet que davant la inoperància de l'autoritat legal (els juristes), haja d'actuar una altra superior (el duc). Aquest canvi de jutge (del racional i correcte a l'irracional i incorrecte, fins i tot salvatge..., però al remat efectiu), és el que provoca la sorpresa i la rialla alliberadora final. Ara bé, malgrat l'aparença d'absència, realment aquest motiu sí que es troba a «La justícia d'Almudévar». La instància superior -com diu la proposta de tipus internacional ATU, $1534 \mathrm{~A}^{*}$ coincideix amb el poble; els vilatans («the village») són: el «labrador», en la versió de Santa

91. L'anècdota s'ha mantingut com a contalla fins avui, i també al refraner aragonés: «Justicia de mal justiciador, lo que hizo el herrero, que lo pague el tejedor», i «La justícia de Almudévar: páguelo el que no deba». 
Cruz; i «uno del pueblo» en la de Braulio Foz. Els contes tradicionals plantegen -posen damunt la taula com a interrogant tàcit- la superioritat moral o pràctica d'aquesta instància vulgar o popular (el rufià insospitat, el poble insensat) per damunt de la instància legal (l'alcalde o els juristes).

Es manté, doncs, l'esquema bàsic de l'argument de l'anècdota, lligat a la sorprenent acceptació d'una decisió arbitrària i injusta. Però si la veu i la mà de l'execució de la justícia era l'autoritat (el duc) al passatge del Tirant -o l'Emperador Tamerlà al passatge de l'Embajada-, aquesta arbitrarietat ha canviat ara al poble, $i$ ha passat del despotisme a l'estupidesa. El llaurador de l'anècdota de Santa Cruz serà ara, d'acord amb l'esperit racionalista i reformista de Braulio Foz, un individu vulgar i inculte, «uno del pueblo $\gg^{92}$.

Però, pel que fa a la comparativa amb l'episodi tirantià, allò important és descobrir com el motiu i relat de la LLEI APLICADA DE MANERA ABSURDA, és a dir, el conte-tipus ATU, 15324A, Law absurdly applied, és en molts aspectes el mateix en tots dos relats.

És cert que des d'un punt de vista de versemblança històrica, el motiu de l'APLICACIó DE LA LLEI ABSURDA funciona negativament (triomfa l'acte bàrbar) als textos de Santa Cruz i Braulio Foz, i positivament (triomfa la justícia absoluta) al text de Tirant (també al de l'Embajada a Tamorlán). Però des del punt de vista literari, aquesta negativitat o positivitat resulten totalment ambigües en tots els casos. «La justícia d'Almudévar» ens ensenya a valorar aquesta ambigüitat per damunt de la literalitat. I tampoc en Tirant o l'Embajada, pel que hem vist fins ara, no sabem si ens parlen d'una actuació correcta o incorrecta. El comú denominador-també comú amb les anècdotes d'ATU, 1534- és l'humor, la rialla davant l'exageració i l'absurd, i el final de victòria de la relativitat moral.

Pedro Saputo, el protagonista de la novel.la de Braulio Foz, quan se'n va adonar del que havien fet els ciutadans d'Almudévar, va tenir la reacció de l'home racional, de l'home il.lustrat (alter ego de Foz) davant la barbàrie salvatge ${ }^{93}$. Va tractar d'impedir-ho, però no va arribar a temps; aleshores «llenóse de horror de tan grande barbaridad». I va a retraure als principals del poble que hagueren consentit aquella salvatjada: «Mas ellos se excusaron, diciendo que no pudieron persuadir a la multitud irracional, ni aun hacerse oír en aquel momento. Y se consumó la barbarie más inicua que vieron los siglos». En canvi, és ben cert, al duc de Lencastre ningú no li retrau la seua «barbaritat»; tot el contrari, el Rei, com hem vist, el felicita per la seua acció enèrgica i quirúrgica de tallar de colp la insurrecció. Tanmateix, hem donat raons suficients per a fer pensar que aquesta no és una proposta de Martorell dirigida a la història.

En cap dels dos textos, Tirant lo Blanc o Pedro Saputo, s'ha de pensar que la literalitat de l'opinió de l'observador extern (el Rei o Pedro Saputo, respectivament), que és qui valora o pondera des de l'exterior l'acció, coincideix amb l'opinió de l'autor (Martorell o Foz). Hi ha un distanciament irònic en tots dos casos sobre un relat folklòric graciós i divertit. Que s'ha d'entendre o jutjar com a facècia, com a divertiment, i en cap cas com a conte instructiu o moralitzador.

El remat de la història de Braulio Foz ens diu que Pedro Saputo està avergonyit de l'acció bàrbara imputable al seu poble, però que també és conscient del poder perillós de la tradició oral -la fama parlera- i que per això intentarà evitar que es difonga la història o llegenda al voltant d'aquests fets (és a dir, el succeit, el conte), i Saputo anuncia a manera de presagi o vaticini: $\ll \mathrm{Si}$ esto llega a saberse, y se sabrà, no dudéis que mientras el mundo sea mundo se citará y recorda-

92. Un home clarament arrelat a la seua terra, que fa servir el fragment més llarg de tot el llibre en el ric dialecte d’alt aragonés: «is a fer», «luciará as relles», «teisidor», «enforcar», etc..

93. Ynduráin (1986) i Amores (1993: 116-117) han analitzat ben bé la transformació del Pedro Saputo folklòric, neci o babau, en home sensat. 
rà con eterno baldón el nombre de Almudévar». Naturalment, aquesta afirmació és paradoxal i ambigua. Saputo / Foz no sols no amaga i calla els fets, sinó que escriu i difon la història. Com diu Amores (1993), la difusió la va poder realitzar la tradició oral, però també el mateix Foz hi va contribuir (segurament més que la tradició). Foz actua en aquest cas, com en altres, irònicament $\mathrm{i}$ «cervantinament». I en aquest sentit, Martorell va actuar també -no seria l'única vegada- irònicament $\mathrm{i}$ «pre-cervantinament».

\section{Conclusions}

Històricament, és més que probable que Martorell vulga criticar, amb més o menys acritud, sarcasme o malvolença, el grup dels juristes amb els quals ha hagut de conviure, ha hagut de discutir... i conviu i discuteix potser diàriament i també mentre escriu la seua novel.la. Gràcies a ells i per culpa seua ha aconseguit èxits i fracassos judicials.

De quina manera -manera literària, dins la seua novel-la- podia conduir aquesta crítica? $\mathrm{O}$ bé seriosament o bé humorísticament (és a dir, satíricament o paròdica). En tot cas, només amb les eines de la retòrica, de la modalització irònica assolida pels gèneres literaris que coneix. I Martorell en coneix, de gèneres i d'exemples! És evident que el novel-lista valencià, tot aprofitant l'aparició de dos gremis de menestrals dins la imitació paròdica d'entrada reial als capítols d'Anglaterra, vol caricaturitzar els «juristes» en general com a inútils incapaços de resoldre conflictes. La caricatura significa una deformació dels referents, i una ridiculització dels models. La sàtira o burla dels juristes o advocats no era rara, sinó força habitual, des de feia temps. I ho continuarà sent a la literatura i al pensament popular fins avui mateix.

Martorell hi fa una aportació creativa i original, i aconsegueix transcendir la caricatura tòpica amb una maniobra de tensió exagerada de la versemblança, operació que fa servir sovint en altres indrets de la novel.la. Aquesta tensió implica l'impacte o xoc de contrast de la versemblança històrica amb una sèrie d'imatges pictòriques i escenogràfiques, i de motius folklòrics i patrons fixos (tipus) de rondalles. Relats que bàsicament tenen a veure amb decisions radicals per a solucionar conflictes difícils. I decisions moltes vegades absurdes per a resoldre litigis o plets igualment absurds. Resolucions arbitràries, il.lògiques i al marge de la llei, però que al remat resulten paradoxalment justes. $O$ vàlides si més no. La raó no la tenen els clients ni la té el jutge: la raó la té la broma de donar-li la volta al paper de tots, i de fer que triomfe aquest món absurd posat a l'inrevés. I aquesta situació de món a l'inrevés la representen molt bé algunes escenes més o menys teatrals que inventen els menestrals quan es volen manifestar públicament en parades civils (com les entrades reials) o desfilades religioses (com les processons del Corpus).

Al Tirant, els ferrers i teixidors són protagonistes, dins una desfilada de «ninots» o momos d'entremés, d'una discòrdia impossible de dirimir i que condueix a una pregunta saducea. Els juristes no són juristes de carn i ossos, sinó titelles que representen estereotipus carnavalescos de la cobdícia i de la traïció, i per això són condemnats, en una mena de roca del Judici final -i per un duc que fa de sant Miquel amb llibre de justícia en una mà i espasa en l'altra- a la pena de mort més cruel possible: dels peus a la forca (com Judes) i, a més, esquarterats (com el traïdor Ganeló).

L'actitud del duc de Lencastre no pot ser de cap de les maneres un exemple: és una total i absoluta barbaritat que, tanmateix, resol un conflicte. Però el duc no és un sant Miquel, ni tampoc no és un Cèsar, ni un Alexandre, ni un Aquil.les, els herois model de Tirant i al Tirant. El duc se situa al nivell dels antiherois de l'Edat Mitjana, al nivell d'un Neró que va amb els advocats a l'infern 
o d'un Herodes que talla el cap dels innocents. Al carnaval tot s'hi val. La barbàrie estúpida dels litigants revoltats (els menestrals), no resolta sinó complicada pels juristes inoperants, és combatuda i resolta amb més barbàrie pel duc.

A la processó de les bodes d'Anglaterra al Tirant, on s'integra l'episodi, el relat juga a ser factual, com una crònica o un dietari d'episodis notables de la vida quotidiana. La relació d'elements i el reflex amb les entrades reials de la corona d'Aragó és indubtable. Però justament perquè aquestes entrades van ser fastuoses, gairebé increibles -i el relat del Tirant tracta de traslladar aquesta fastuositat amb realisme documental i perícia retòrica-, els seus elements de «magnificència» ensopeguen amb els mecanismes imbuïts dins l'imaginari de l'espectador de representacions medievals, o de l'oïdor acostumat als motius dels relats folklòrics.

I de la topada surt l'humor. Com passa amb els acudits més sorprenents i amb les rondalles més seductores, aquests dos tipus de relats -l'històric o mimètic, i el folklòric o fabulós- haurien de discórrer amb línies paral.leles, en principi distants o en direccions oposades. Però quan prenen contacte sobtadament, esclaten i deixen el lector esbalaït, sense capacitat de resposta. És el mecanisme de sorpresa i trencament d'expectatives de la rialla, ben definit des de Bergson. Com en altres ocasions a la novel.la, la col.lisió de cop i volta entre dos elements estranys pot produir i conduir -com en un encontre fortuït i venturós-, primer a la desorientació, després a l'esbargiment, i finalment a una distensió burlesca, desembarassada, alegre i franca.

\section{Bibliografia}

Amores García, Montserrat (1993), «Del folclor a la Literatura: Vida de Pedro Saputo», Revista de Dialectología y Tradiciones Populares, 48, pp. 103-123.

BAldissera, Andrea (2000), «Le fonti del Libro de los exemplos por A.B.C. di Clemente Sánchez de Vercial», en Le letterature romanze del Medioevo: testi, storia, intersezioni (V Convegno Nazionale. Roma 23-25 ottobre 1997), a cura di Antonio Pioletti, Soveria Mannelli, Rubbettino, pp. 295-309.

BAzÁn, Iñaki (2007), «La pena de muerte en la Corona de Castilla en la Edad Media», Clío \& Crimen, 4, pp. 306-352.

Beltran, Rafael (1997), «Urganda, Morgana y Sibila: el espectáculo de la nave profética en la literatura de caballerías», en The Medieval Mind. Hispanic Studies in Honour of Alan Deyermond, eds. Ian Macpherson i Ralph Penny, Londres, Tamesis, 1997, pp. 21-47.

(2001), «Huellas de las oraciones de Los Tres Reyes de Oriente y Las cuatro esquinitas en Tirant lo Blanc», en Lyra Minima Oral. Los géneros breves en la poesía tradicional, ed. Carlos Alvar, Cristina Castillo, Mariana Masera i José Manuel Pedrosa, Alcalá de Henares, Univ. de Alcalá, pp. 415-24.

(2006a), «Tirant lo Blanc», de Joanot Martorell, Madrid, Síntesis.

(2006b), «La princesa que no sabia l'endevinalla: models rondallístics a l'episodi de Felip i

Ricomana al Tirant lo Blanc», en El cuento folclórico en la literatura y en la tradición oral, eds. Rafael Beltrán i Marta Haro, València, Publicacions de la Universitat de València, 2006, pp. 57-87.

(2019), «"Humos escuros y espesas nieblas" en los primeros ataques a los libros de caba-

llerías: Tirante el Blanco (1511) frente a las críticas de Juan de Molina, Luis Vives y Jerónimo Sempere», Historias fingidas, 7, pp. 61-127.

(2020), «Del suicidio de Judas al salto de Pármeno: codicia, traición y caídas mortales en $\mathrm{La}$ Celestina», Celestinesca, 44, pp. 9-80. 
Bermejo Cabrero, José Luis (2005), Poder político y administración de justicia en la España de los Austrias, Madrid, Ministerio de Justicia.

Bertran, Jordi (2017), «La construcció de la festa en l'escena de la urbs: el trànsit del segle XV al XVI», Revista de poética medieval, 31, pp. 71-85.

Borràs Barberà, Marc i Luis Pablo Martínez Sanmartín (1990), «Tirant lo Blanc, novel.la moderna?: Mutació social i reacció ideològica a la fi de l'Edat Mitjana», Afers, 10, pp. 275-300.

BRISSET MARTín, Demetrio E. (2000), «Imagen y símbolo en el personaje ritual del Judas», Gazeta de antropologia, 16. Disponible en: <http://hdl.handle.net/10481/7500>.

Brummer, Rudolf (1962), «Die Episode von Köning Artus im Tirant lo Blanc», Estudis Romànics, 10, pp. 283-290.

Bueno TÁrrega, Baltasar (2016), La procesión de Corpus Christi de Valencia, València, Fundación Joaquín Díaz.

CACho CASAL, Rodrigo (2003), La poesia burlesca de Quevedo y sus modelos italianos, Santiago, Universidade de Santiago de Compostela.

Calvé MasCarell, Óscar (2016), La configuración de la imagen de san Vicente Ferrer en el siglo XV, Tesi doctoral, València, Universitat de València.

(2019), «L'entramès de Mestre Vicent: resplandor de la autoridad del predicador», Anuario de estudios medievales, 49, 1, pp. 45-73.

Campos Ocampo, Melvin i Tatiana Herrera Ávila (2006), «Sancho Panza y el carnaval salomónico (Batucada Barataria)», Filologia y Lingüística (Universidad de Costa Rica), 22, 1, pp. 9-35.

Cantavella, Rosanna (2003), «Debate on Women in Tirant lo Blanc», en The Querelle des Femmes in the Romania: Studies in Honour of Friederike Hassauer, eds. W. Aichinger, M. Bidwell Steiner, J. Bösch o E.Cescutti, Viena, Turia und Kant, pp. 45-56.

CÁrcel Ortí, Milagros, i Juan Vicente García Marsilla (eds.) (2013), Documents de la pintura valenciana medieval i moderna, IV. Llibre de l'entrada de Ferran d'Antequera, València, Universitat de València.

CARrasco Manchado, Ana Isabel (2013), «Las entradas reales en la corona de Castilla: pacto y diálogo político en torno a la apropiación simbólica del espacio urbano», en Marquer la ville: Signes, traces, empreintes du pouvoir (XIIIe-XVIe siècle) [en línea]. Paris-Rome, Éditions de la Sorbonne. Disponible en: <http://books.openedition.org/psorbonne/3284>.

Carrero Santamaría, Eduardo (2016), «La procesión, memoria litúrgica del Medievo en la pintura de la Edad Moderna», Quadrivium. Revista Digital de Musicologia, 7, pp. 142-158.

Cervantes, Miguel de (1998), Don Quijote de la Mancha, ed. Francisco Rico, Barcelona, Instituto Cervantes-Crítica, 2 vols.

Chevalier, Maxime (1978), Folklore y literatura: el cuento oral en el Siglo de Oro, Barcelona, Crítica. (1981), «Huellas del cuento folklórico en El Quijote», en Cervantes: su obra y su mundo (Actas del I Congreso Internacional sobre Cervantes), ed. M. Criado de Val, Madrid, Edi-6, pp. 881-893. (1989), «Sancho Panza y la cultura escrita», en Studies in Honour of Bruce W. Wardropper, ed. Dian Fox et al., Newark, Delaware, Juan de la Cuesta, pp. 67-73.

(1991), «La primera mención de Pedro Saputo», Archivo de filología aragonesa, 46-47, pp. 9-12.

(1998), «Don Quijote, Segunda Parte; capítulos 45, 47 y 49», en Don Quijote de la Mancha, ed. Francisco Rico, Barcelona, Instituto Cervantes-Crítica, vol. II, pp. 187-193.

(1999), Cuento tradicional, cultura, literatura (siglos XVI-XIX), Salamanca, Universidad de Salamanca. 
Córdoba de la Llave, Ricardo (2005), «El homicidio en Andalucía a fines de la Edad Media», Clío \& Crimen, 2, pp. 453-504.

Cover, Robert M. (1985), «The Folktales of Justice: Tales of Jurisdiction», Faculty Scholarship Series. Paper 2706. Disponible en: <http://digitalcommons.law.yale.edu/fss_papers/2706>.

Cruselles Gómez, José María (1992), «Los juristas valencianos en la Italia renacentista: estudiantes y cortesanos», Revista de Història Medieval, 3, pp. 143-160.

(1998), Els notaris de la ciutat de València: activitat professional i comportament social a la primera meitat del segle $X V$, Barcelona, Pagès.

(2012-2014), «Francesc Eiximenis y la política escolar de la ciudad de Valencia (13891412)», Anales de la Universidad de Alicante: Historia medieval, 18, pp. 271-301.

De ANDrÉs DíAZ, Rosana (1984), «Las 'entradas reales' castellanas en los siglos XIV y XV, según las crónicas de la época», En la España medieval, 4, pp. 47-62.

Dueñas Ruiz, Óscar José (2009), Lecciones de hermenèutica jurídica, Bogotá, Univesidad del Rosario.

EsCARTí, Vicent Josep (2012), «Els Capítols de nomenament de Joanot Martorell com a procurador del comtat de Dènia. Una aportació a la controvertida identitat de l'autor del Tirant», Estudis romànics, 34, pp. 389-403.

Espadaler, Anton (2000), «El Tirant com a comèdia. Els amors de Felip i Ricomana», Revue d'Études Catalanes, 3, pp. 39-58.

(2019), «Religió i religiositat en el Tirant lo Blanc», Scripta, 14, 1, pp. 261-275.

FerRANDo FrancÉs, Antoni (2012), «Llengua i context cultural al Tirant lo Blanc. Sobre la identitat del darrer Joanot Martorell (1458-1465)», eHumanista, 22, pp. 623-668.

Ferrer Valls, Teresa (1994), «La fiesta cívica en la ciudad de Valencia en el siglo XV», en Cultura y representación en la Edad Media: Actas del seminario celebrado con motivo del II Festival de Teatre i Música Medieval d'Elx (octubre-noviembre de 1992), coord. Evangelina Rodríguez, Alacant, Diputació Provincial d'Alacant-Instituto Alicantino de Cultura 'Juan Gil-Albert', pp. 145-169.

(1995), «De los entremeses de circunstancias políticas a las piezas dramáticas de circunstancias políticas: el preludio del drama histórico barroco», en Francesc Massip (ed.), Formes teatrals de la tradició medieval (Actes del VII Col-loqui de la Société Internationale pour l'Étude du Théâtre Medieval), Barcelona, Institut del Teatre-Diputació de Barcelona, pp. 417-424.

GALÉ, Enrique (1996-1997), «Aspectos estamentales de la caballería en Tirant lo Blanc», Revista de lenguas y literaturas catalana, gallega y vasca, 5, pp. 59-88.

GACTÓ FernándeZ, E. (1982), «La administración de justicia en la obra satírica de Quevedo», en Academia Literaria Renacentista, II, Homenaje a Quevedo, Salamanca, Univ. de Salamanca, pp. 133-62.

Goldberg, Harriet (1998), Motif-Index of Mediaeval Spanish Folk Narratives, Tempe (Arizona), Medieval \& Renaissance Texts \& Studies.

González de Clavijo, Ruy (1999), Embajada a Tamorlán, ed. Francisco López Estrada, Madrid, Castalia.

Gómez Muntané, Maricarmen (2010), «El papel de la música en Tirant lo Blanc (Valencia, 1490)», Tirant, 13, pp. 27-38.

González Montañés, Julio Ignacio (2002), Drama e iconografía en el arte medieval peninsular (siglos XI-XV), Tesi doctoral, Madrid, UNED.

Graullera Sanz, Vicente (2009), Derecho y juristas valencianos en el siglo XV, València, Biblioteca Valenciana. 
Guia I MARÍn, Josep (2001), «Concordances curioses dels antropònims 'Tirant lo Blanc' i 'Carmesina'», en Congrés Internacional de Toponímia i Onomàstica Catalanes (València, 18-21 d'abril de 2001), València, Universitat de València, pp. 591-601.

Gutiérrez Martínez, M.a del Mar (2009-2010), «Edición del Libro de los exemplos por A.B.C. (1 ${ }^{\text {a }}$ parte $) \gg$, Memorabilia, 12, pp. 1-212.

Hanauer, J. E. (1935), Folk-Lore of the Holy Land: Moslem, Christian, and Jewish, Londres, The Sheldon Press.

HARney, Michael (2005), «Amity and Polity in Spanish Chivalric Romances», en Historicist Essays on Hispano-Medieval Narrative: In Memory of Roger M. Walker, ed. Barry Taylor i Geoffrey West, 'Publications of the Modern Humanities Research Association', vol. 16, Londres, Maney Publishing for the Modern Humanities Research Association, pp. 135-170.

Hauf, Albert (1990), «Artur a Constantinoble. Entorn un curiós episodi del Tirant lo Blanc», L’Aiguadolç, 12-13, pp. 13-33. , ed. (2004), Joanot Martorell, Tirant lo Blanch, València, Tirant lo Blanch.

Insuela, A. F. (1992), «El cuento de 'las sentencias agudas' (AT 1534): Una nueva versión y algunos datos históricos», RILCE, 8, pp. 29-40.

Keller, John E. (1949), Motif-Index of Mediaeval Spanish Exempla, Knoxville, Tennessee, Univ. of Tennessee Press.

, ed. (1960), Clemente Sánchez de Vercial, El libro de los exenplos por A. B. C., Madrid, C. S. I. C.

KHAZAIE, Davood (2017), «Justice and Injustice in a Society Ruled by Scoundrels», Persian Literary Studies Journal, 6, 10, pp. 125-172.

Kovács, Lenke (2008), «La mort del traïdor Judes com a antítesi de la mort redemptora de Crist en el teatre medieval i europeu», en Estudios sobre el teatro medieval, ed. Josep Lluís Sirera, València, PUV, pp. 117-129.

Lecoy, Félix (1938), Recherches sur le «Libro de buen amor» de Juan Ruiz, Archiprêtre de Hita, París, Droz.

López Arnal, Salvador (2006), «Paradojas en el Quijote», dins el seu blog Rebelión: https:// rebelion.org/paradojas-en-el-quijote/

López Quiles, Antoni (2007), Literatura i espiritualitat. Aproximació a l'obra de Corella com a resposta davant Déu i l'home, València, Institució Alfons el Magnànim.

Mainer, José-Carlos (1989), «Braulio Foz y la Vida de Pedro Saputo», Letras Aragonesas (siglos XIX y XX), Zaragoza, Oroel, pp. 59-75.

Mantecón Movellá, Tomás (2015), «Ciudad, policía y desobediencia cívica en la España del Antiguo Régimen: experiencias históricas contrastadas», Identidades urbanas en la monarquía hispánica (siglos XVI-XVIII), Santiago de Compostela, Universidade de Santiago, pp. 237-268.

Márquez Villanueva, Francisco (1985), «Letrados, consejeros y justicias», Hispanic Review, 53 (1985), pp. 201-27.

MARTínez Vinat, Juan (2018), Cofradías y oficios. Entre la acción confraternal y la organización corporativa en la Valencia medieval (1238-1516), Tesi doctoral, Univ. de València.

Martorell, Joanot (2004), Tirant lo Blanch, ed. Albert Hauf, València, Tirant lo Blanch.

Massip Bonet, Francesc (2010), A cos de rei. Festa cívica i espectacle del poder reial a la Corona d'Aragó, Valls, Cossetània.

(2011), «Motivos caballerescos en el teatro medieval», en Epica e cavalleria nel medioevo (Atti del Seminario internazionale, Torino, 18-20 novembre 2009), eds. Marco Piccat i Laura Ramello, Alessandria, Dell'Orso, pp. 167-194. 
(2013-2014), «L'entrada valenciana dels primers Trastàmares», Locus Amoenus, 12, pp. 5565.

MuÑoz Gómez, Víctor (2018), «¿Representar la legitimidad? Objetos, símbolos y comunicación en las ceremonias públicas del reinado de Fernando I de Aragón», Medievalista on line, 23. Disponible en: <http://www2.fcsh.unl.pt/iem/medievalista/MEDIEVALISTA23/gomez2312. html>.

Narbona Vizcaíno, Rafael (1993), «Las fiestas reales en Valencia entre la Edad Media y la Edad Moderna (siglos XIV-XVII) », Pedralbes. Revista d'Història Moderna, 13/2, pp. 463-472. (1995), Valencia, municipio medieval: poder politico y luchas ciudadanas (1239-1418), València, Ajuntament de València.

(2003), «Las entradas reales en Valencia entre la Edad Media y la Edad Moderna. Siglos XIV-XVII», dins el seu Memorias de la ciudad. Ceremonias, creencias y costumbres en la historia de Valencia, València, Ajuntament de València, pp. 85-100.

(2012-2014), «La justicia municipal en el Reino de Valencia (ss. XIII-XV)», Anales de la Universidad de Alicante. Historia Medieval, 18, pp. 347-357.

(2016), «Competencia, conflicto y violencia en la manufactura cerámica valenciana del siglo $\mathrm{XV} \gg$, en Identidades urbanas. Corona de Aragón-Italia. Redes económicas, estructuras institucionales, funciones públicas (siglos XIV-XV), eds. P. Iradiel, G. Navarro, D. Igual, C. Villanueva, Saragossa, Prensas de la Universidad de Zaragoza, pp. 45-59.

(2017), La ciudad y la fiesta: cultura de la representación en la sociedad medieval (siglos XIII-XV), Madrid, Síntesis.

(2019a), «Bandos populares en la Valencia del Trescientos. Obligaciones de reciprocidad, socorro y consejo en la sociabilidad urbana», en Élites, conflictos y discursos políticos en las ciudades bajomedievales de la Península Ibérica, ed. José María Monsalvo Antón, Salamanca, Universidad de Salamanca, pp. 271-296.

(2019b), «Ruzafa, una comunidad rural convulsa (1395-1403)», en Expresiones de poder en la Edad Media. Homenaje a Juan Antonio Bonachía, Valladolid, Universidad de Valladolid, pp. 429-439.

NeugaArd, Edward J. (1993), Motif-Index of Medieval Catalan Folktales, 'Medieval \& Renaissance Texts \& Studies', 96, Nova York, Binghamton.

Nieto Soria, José Manuel (1993), Ceremonias de la realeza. Propaganda y legitimación en la Castilla Trastámara, Madrid, Nerea.

OlezA, Joan (1992), «Tirant lo Blanch y la ansiedad de ficción del caballero Martorell», en Historias y ficciones: Coloquio sobre la literatura del siglo XV, eds. R. Beltran, J. L. Canet i J. L. Sirera, València, PUV, pp. 323-335.

Oller y Bono, Mauro Antonio (1759), Proclamación del rey N. ${ }^{\text {tro }} S .{ }^{\text {or }} D .{ }^{n}$ Carlos III. (que Dios guarde) en su fidelissima ciudad de Valencia, presentada al público en esta memoria, València, Oficina de la Viuda de Joseph de Orga.

Oriol, Carme i Josep Maria Pujol (2003), Índex tipologic de la rondalla catalana, Barcelona, Generalitat de Catalunya.

ORTs-Ruiz, Francisco (2019), «De crides, balls, entremesses y cobles. Las celebraciones por la entrada de Juan II y Juana Enríquez en Valencia (1459) como paradigma de la unión de las artes en la fiesta urbana medieval», Matèria, 14-15, pp. 97-116.

PARMA, Mariana V. (2001-2002), «Fiesta y revuelta. La teatralidad política en Valencia a principios de la modernidad», Cuadernos de Historia de España, 77, pp. 145-164. 
Pedrosa, José Manuel i Awa Traoré (2014), «"Los dos perezosos” (ATU 1950) de Juan Ruiz y la tradición oral diula de Costa de Marfil: traducción, transmisión, tradición», eHumanista, 28, pp. 643-699.

Pérez GonzÁlez, Ana (2016), «El Castillo de Amor en las artes figurativas bajomedievales», Revista Digital de Iconografía Medieval, VIII, 16, pp. 5-30.

Pons, Antonio (1960), «Los judíos del reino de Mallorca durante los siglos XIII y XIV», Hispania, 20, pp. 449-453.

Puchades i Bataller, Ramon J. (1999), Als ulls de Déu, als ulls dels homes: Estereotips morals i percepció social d'algunes figures professionals en la societat medieval valenciana, 'Seminari Internacional d'Estudis sobre la Cultura Escrita', València, Univ. de València.

Raufast Chico, Miguel (2006a), «iNegociar la entrada del rey?: La entrada real de Juan II en Barcelona», Anuario de estudios medievales, 36/1, pp. 295-333.

(2006b), «E vingueren los officis e confraries ab llurs entremeses e balls». Una aproximación al estamento artesanal en la Barcelona bajomedieval, a partir del estudio de las ceremonias de entrada real», Anuario de estudios medievales, 36/2, pp. 651-686.

(2006-2007), «La entrada real de Martín el Joven, rey de Sicilia en Barcelona (1405): solemnidad, economía y conflicto», Acta historica et archaeologica mediaevalia, 27-28, pp. 89-120 (2007) $\ll_{i}$ Un mismo ceremonial para dos dinastías? Las entradas reales de Martín el Humano (1397) y Fernando I (1412) en Barcelona», En la España Medieval, 30, pp. 91-130.

(2010), «Imágenes para una ceremonia: la entrada real en la Barcelona bajomedieval», en G. T. Colesanti (ed.), Le usate leggiadrie. I cortei, le cerimonie, le feste e il costume nel Mediterraneo tra il XV e XVI secolo, Montella, Centro Francescano di Studi sul Mediterraneo, pp. 162-199.

Redondo, Augustin (1978), «Tradición carnavalesca y creación literaria del personaje de Sancho Panza al episodio de la ínsula Barataria en el Quijote», Bulletin Hispanique, 80, pp. 39-70.

Renedo Puig, Xavier (2019), «Uva, ciliegie, nòccioli e "qualità femminili": da un exemplum di Bernardino da Siena alla comparació de la vinya del Tirant lo Blanc», Aevum, 93, pp. 629-667.

(2020), «La ficció teatral del rei Artús (Tirant lo Blanc, 189-202)», Romance Philology, 74, pp. 37-92.

RiQuer, Martí de (1972), Literatura Catalana Medieval, Barcelona, Ajuntament de Barcelona. (1990), Aproximació al «Tirant lo Blanc», Barcelona, Quaderns Crema.

Rodríguez BARral, Paulino (2007), La justicia del más allá: Iconografía en la Corona de Aragón en la baja Edad Media, València, PUV.

Rubió i BALAguer, Jordi (1953), «Literatura catalana», en Historia General de las Literaturas Hispánicas, ed. Guillermo Díaz-Plaja, Barcelona, Barna, vol. III, pp. 727-930.

Rubio Vela, Agustín (1985), Epistolari de la València medieval, València, Institut de Filologia Valenciana, 2 vols.

(2010), Joanot Martorell y el condado de Dénia. Una clave en el «Tirant», València, Gràfiques Papallona.

Ruiz, Arcipreste de Hit A, Juan (1990), Libro de buen amor, ed. Jacques Joset, Madrid, Taurus. SALICRÚ I LLUCH, Roser (1995), «La coronació de Ferran d'Antequera: l'organització i els preparatius de la festa», Anuario de Estudios Medievales, 25/2, pp. 699-758.

SANZ, María Jesús (1997), «El corpus en Sevilla a mediados del siglo XVI. Castillos y danzas», Laboratorio de Arte, 10, pp. 123-137.

SASOR, Rozalya (2008), «Tirant lo Blanc de Joanot Martorell: novela e historia», Studia Litteraria Universitatis Iagellonicae Cracoviensis, 3, pp. 109-120. 
Schwarz, Lía (1986), «El letrado en la sàtira de Quevedo», Hispanic Review, 54, pp. 27-46. Schwarzbaum, Heim (1968), Studies in Jewish and World Folklore, Berlín, De Gruyter.

Strosetzki, Christoph (2019), «Satíras judiciales de Sancho y don Quijote», Hipogrifo, 7.1, pp. 701-711.

SuÁrez López, Jesús (1988), Cuentos del Siglo de Oro en la tradición oral de Asturias, Gijón, Museo del Pueblo de Asturias.

Thompson, Stith (1955-1958), Motif-Index of Folk Literature, Copenague i Bloomington, Indiana Univ. Press, 6 vols.

Toldrà I Vilardell, Albet (2018), «Judes-Èdip en l'edat mitjana», Scripta, 12, pp. 143-151.

Uther, Hans-Jörg (2004), The Types of International Folktales. A Classification and Bibliography, Based on the System of Antti Aarne and Stith Thompson, Hèlsinki, Suomalainen TiedeakatemiaAcademia Scientiarum Fennica, 3 vols.

Vargas Llosa, Mario (1981), Lletra de batalla per «Tirant lo Blanc», Barcelona, Edicions 62 [1 ${ }^{\text {a }}$ ed. 1969].

Ynduráin, Francisco i Domingo Ynduráin, eds. (1986), Braulio Foz, Vida de Pedro Saputo, Madrid, Cátedra. 